\title{
National Water Quality Assessment of the Georgia-Florida Coastal Plain Study Unit- Water Withdrawals and Treated Wastewater Discharges, 1990
}

By Richard L. Marella and Julia L. Fanning

U.S. GEOLOGICAL SURVEY

Water-Resources Investigations Report 95-4084

U.S. GEOLOGICAL SURVEY

NATIONAL WATER-QUALITY ASSESSMENT PROGRAM

GEORGIA-FLORIDA COASTAL PLAIN STUDY UNIT

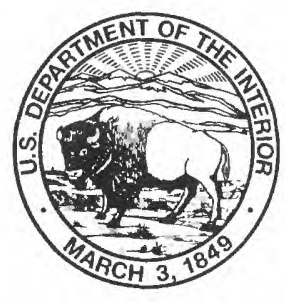




\title{
U.S. DEPARTMENT OF THE INTERIOR BRUCE BABBITT, Secretary
}

\author{
U.S. GEOLOGICAL SURVEY \\ Gordon P. Eaton, Director
}

Any use of trade, product, or firm names in this publication is for descriptive purposes only and does not imply
endorsement by the U.S. Geological Survey.

For additional information write to:

Copies of this report can be purchased from:

District Chief

U.S. Geological Survey

Suite 3015

227 North Bronough Street

Tallahassee, Florida 32301
U.S. Geological Survey Earth Science Information Center Open-File Reports Section

P.O. Box 25286, MS 517

Denver, CO 80225-0425 


\section{CONTENTS}

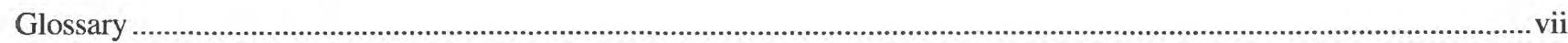

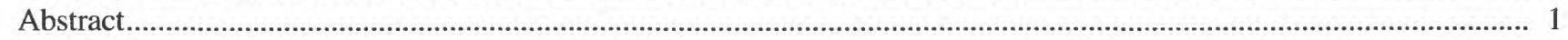

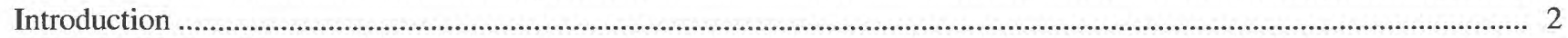

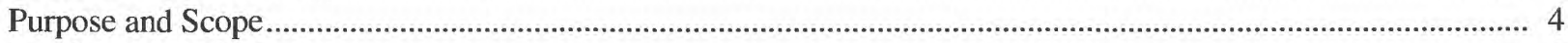

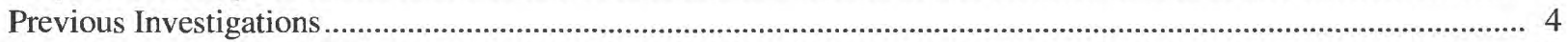

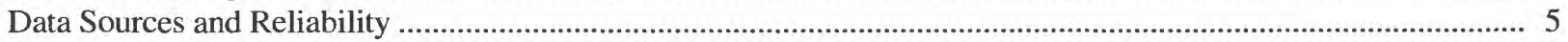

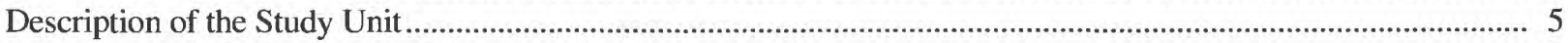

Water Withdrawals in the Georgia-Florida Coastal Plain Study Unit .................................................................... 7

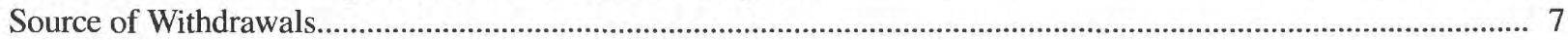

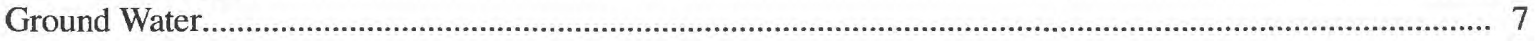

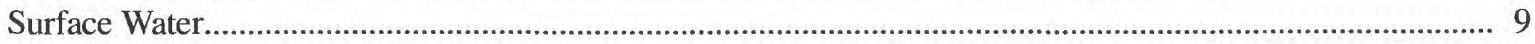

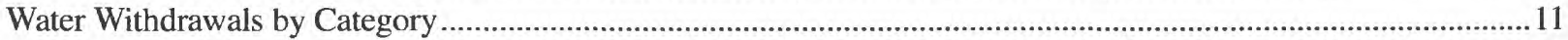

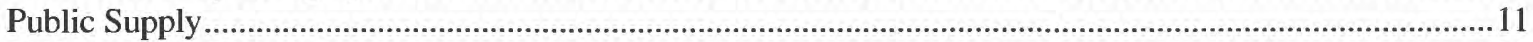

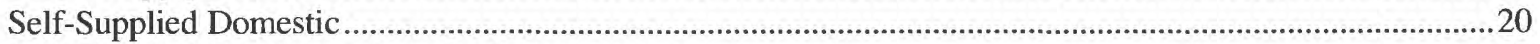

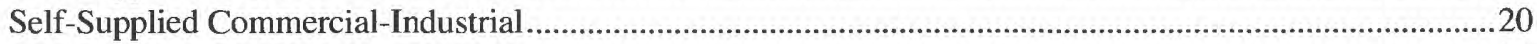

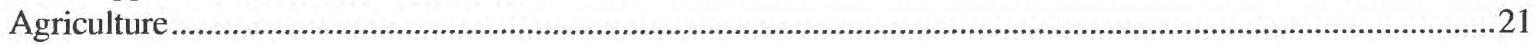

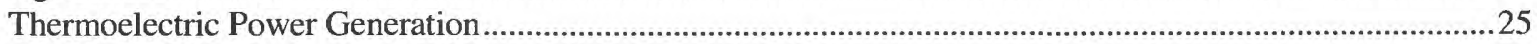

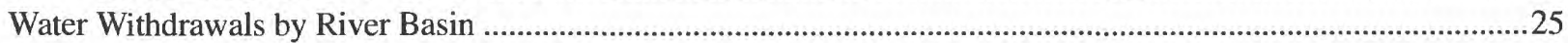

Treated Wastewater Discharges in the Georgia-Florida Coastal Plain Study Unit..........................................................30

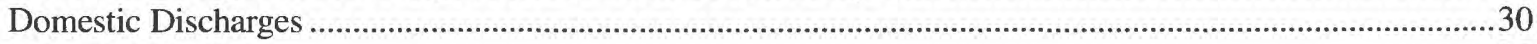

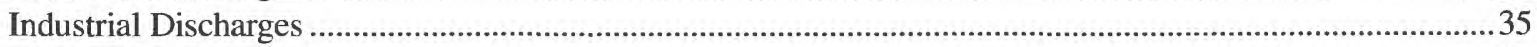

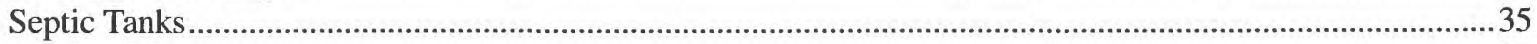

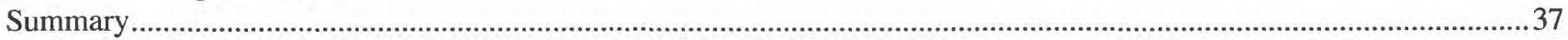

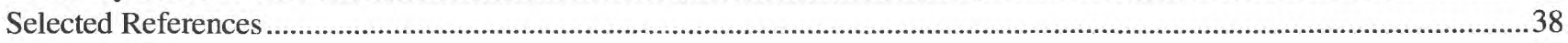

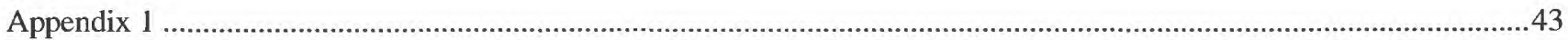

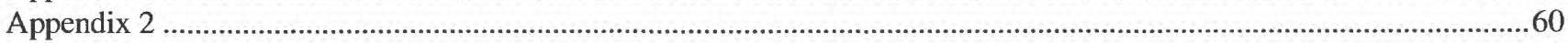

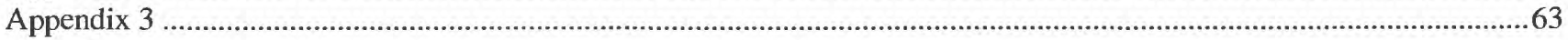

\section{ILLUSTRATIONS}

1-12. Maps showing:

1. Locations of selected cities and major rivers in the Georgia-Florida Coastal Plain study unit...................... 2

2. General location of and ground-water withdrawals from principal aquifers in the

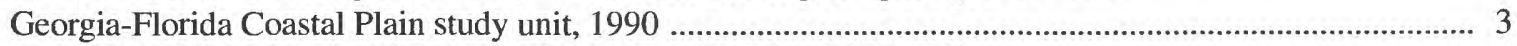

3. Locations of counties in the Georgia-Florida Coastal Plain study unit ...................................................... 6

4. Ground-water withdrawals by county in the Georgia-Florida Coastal Plain study unit,1990 ..................... 8

5. Surface-water withdrawals by county in the Georgia-Florida Coastal Plain study unit,1990 .......................10

6. Graph showing ground- and surface-water withdrawals by water-use categories in the Georgia-Florida Coastal Plain study unit, 1990 ....................................................................................11

7. Graph showing freshwater withdrawals by water-use categories in the Georgia-Florida

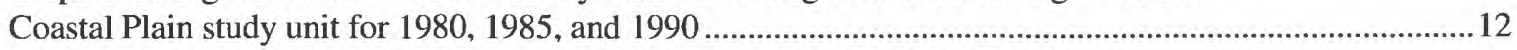

8. General locations of the largest public-supply utilities in the Georgia-Florida

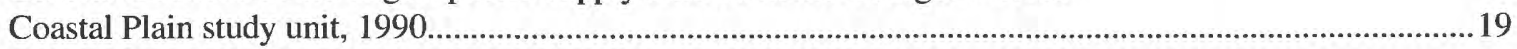

9. General locations of the largest self-supplied commercial-industrial facilities in

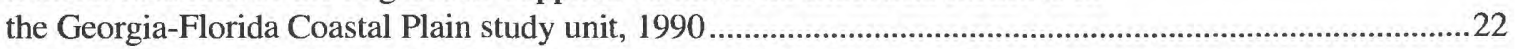

10. General locations of the more intensively irrigated agricultural areas in the Georgia-Florida Coastal Plain study unit, 1990 
11. General locations of the self-supplied thermoelectric power generation facilities in the Georgia-Florida Coastal Plain study unit, 1990.

12. Locations of major river basins in the Georgia-Florida Coastal

Plain study unit

13-15. Graphs showing:

13. Ground- and surface-water withdrawals by major river basin in the Georgia-Florida

Coastal Plain study unit, 1990

14. Treated wastewater discharge by county in the Georgia-Florida Coastal

Plain study unit, 1990

15. Map showing general locations of the largest domestic wastewater facilities in the Georgia-Florida

Coastal Plain study unit

\section{TABLES}

1. Freshwater withdrawals and reclaimed wastewaterby principal water-use category in the

Georgia Florida Coastal Plain study unit, 1990

2 Ground-water withdrawals by principal aquifer in the Georgia-Florida Coastal

Plain study unit, 1990

3. Freshwater withdrawals by source and water-use category the Georgia-

Florida Coastal Plain study unit, 1980-90

4. Freshwater withdrawals by source and by principal water-use category for

the counties in the Georgia-Florida Coastal Plain study unit, 1990

5. Population and freshwater withdrawals by major river basin (subregion) in the Georgia-Florida Coastal Plain study unit, 1990

6. Estimated wastewater discharge, population served, and number of septic tanks by county in the Georgia-Florida Coastal Plain study unit, 1990

CONVERSION FACTORS

\begin{tabular}{rcl}
\hline Multiply & By & To obtain \\
\hline acres & 4,047 & square meters \\
acres & 0.00156 & square mile \\
square miles $\left(\mathrm{mi}^{2}\right)$ & 2.59 & square kilometer \\
gallons per day $(\mathrm{gal} / \mathrm{d})$ & 3.785 & liters per day \\
million gallons per day $(\mathrm{Mgal} / \mathrm{d})$ & 0.003785 & million cubic meters per day \\
\hline
\end{tabular}

\section{ADDITIONAL ABBREVIATIONS}

FDEP = Florida Department of Environmental Protection

$\mathrm{mg} / \mathrm{L}=$ milligrams per liter

MSA $=$ metropolitan statistical area

NAWQA = National Water Quality Assessment Program

USGS = U.S. Geological Survey 


\section{GLOSSARY}

Aquifer---A geologic formation, group of formations, or part of a formation that contains sufficient saturated material to yield significant quantities of water to wells and springs.

Agricultural water use.--Includes water used for irrigation and nonirrigation purposes. Irrigation water use includes the artificial application of water on lands to assist in the growing of crops and pasture grasses, or to maintain vegetative growth in recreational lands, parks, and golf courses. Nonirrigation water use includes water used for livestock, fish farming, and other farm needs. Livestock water use includes water used for stock watering, feedlots, and dairy operations.

Cesspool.--An underground catch basin for liquid waste, such as household sewage. See septic tank.

Commercial water use.--Water for motels, hotels, restaurants, office buildings, commercial facilities as well as civilian and military institutions. The water may be obtained from a public supply or may be self-supplied.

Consumptive use.--That part of water withdrawn that is evaporated, transpired, incorporated into products or crops, consumed by humans or livestock, or otherwise removed from the immediate water environment. Sometimes called water consumed or water depleted. Additionally, any water withdrawn in the basin and transferred out of the basin for use is considered 100 percent consumptively used.

Cooling water.--Water used for cooling purposes by electric generators, steam condensers, large machinery or products at manufacturing facilities. Water used for cooling purposes can be either fresh or saline and may be obtained from a public supply water system or be self-supplied. Cooling water may be used only once or recirculated multiple times.

Desalination.--Refers to the removal of salts from water. Desalination is primarily used for public supply water to ensure that it meets Florida Department of Environmental Protection secondary drinking standards (see potable water). The primary types of desalination are: (1) distillation, (2) electrodialysis, and (3) reverse osmosis (Buros, 1989; South Florida Water Management District, 1990). Reverse osmosis is the most commonly used processes in Florida followed by electrodialysis (Dykes and Conlon, 1989). Additionally, many public suppliers also dilute or blend brackish or saline water with fresher water to produce potable water. Also see reverse osmosis.

Dewatering.--The deliberate attempt to lower the ground-water level for selected purposes such as agricultural, construction, mining or other activities. For mining operation, dewatering is usually accomplished by pumping the water out of the ground and discharging the water to a surface-water body. However, some dewatering involves gravity feeding water from the surficial aquifer into the deeper aquifer (usually the Floridan aquifer system) through recharge wells (Campbell, 1986, p. 36).

Disposal system or method.--Refers to injection wells, outfalls, drain fields, percolation ponds, spray fields, and other facilities utilized for the release of reclaimed or treated effluents to the environment.

Domestic wastewater facility.--Refers to those facilities that receive or dispose of wastewater principally derived from residential dwellings, business or commercial buildings, institutions, and the like; sanitary wastewater; sewage (Florida Department of Environmental Regulation, 1991). Can also include some wastewater derived from industrial facilities. May also be referred to as a municipal wastewater facility.

Domestic water use.--Water for normal household purposes, such as drinking, food preparation, bathing, washing clothes and dishes, flushing toilets, and watering lawns and gardens. Also called residential water use. Water used for domestic purposes may be obtained from a public-supply system or it may be self-supplied from individual wells. 
Drain field.--A network of buried piping or tubing where the fluid is discharged to the ground through seepage. Most common use is with septic tanks, but can also be used for domestic or industrial wastewater disposal after other treatment methods.

Effluent.--Refers to the water that flows out of a wastewater-treatment facility or other works used for the purpose of treating, stabilizing, or holding waste.

Flood irrigation.-- Irrigation systems that control the water table with lateral supply ditches. These include open field ditch systems (furrows), semi-closed conveyance systems, subsurface conduit systems, crown flood systems, and continuous flood systems. Also referred to as seepage or subsurface irrigation. The efficiencies of these flood irrigation systems range from 20 to 80 percent (Smajstrla and others, 1988), however, the average of 60 percent is commonly used for estimating water requirements.

Freshwater.--Water that contains less than $1,000 \mathrm{mg} / \mathrm{L}$ (milligrams per liter) of dissolved solids; generally, more than $500 \mathrm{mg} / \mathrm{L}$ dissolved solids is considered undesirable for drinking and many industrial uses. Generally, freshwater is considered potable.

Ground water:--Specifically, that part of the subsurface water that is in the saturated zone (a zone, in which all voids are filled with water.

Ground-water disposal.--Refers to wastewater that is disposed of through the ground by injection or seepage. This includes the following discharge methods: absorption beds, injection wells, drain fields, percolation ponds, rapid infiltration basins, and spray fields (land application). Land-application systems (reuse systems) are considered a ground-water disposal method, as the effluent used to irrigate turf or crops generally percolates down through the soil despite a percentage of the water that evaporates into the atmosphere or runs off.

Hydroelectric power water use.--Water used to generate electricity at plants where turbine generators are driven by falling water. Water used for hydroelectric purposes is considered an instream use of water and is generally a nonconsumptive use of water.

Industrial-wastewater facility.--Refers to those facilities that produce, treat, or dispose of wastewater not otherwise defined as domestic wastewater; includes water runoff and leachate from areas that receive pollutants associated with industrial or commercial storage, handling, or processing (Florida Department of Environmental Protection, 1991).

Industrial water use.--Water used for industrial purposes such as fabricating, processing, washing, and cooling, and includes such industries as steel, chemical and allied products, paper and allied products, mining, and petroleum refining. The water may be obtained from a public supply or may be self-supplied.

Injection well.--Refers to a well constructed for the purpose of injecting treated wastewater directly into the ground. Wastewater is generally forced (pumped) into the well for dispersal or storage into a designated aquifer. Injection wells are generally drilled into nonpotable aquifers, unused aquifers, or below freshwater levels in these aquifers.

Instream use.--Water use taking place within the stream channel for such purposes as hydroelectric power generation, navigation, water-quality improvement, fish and wildlife propagation, and recreation. Sometimes called nonwithdrawal use or inchannel use.

Land application.--The application of reclaimed water or effluents on, above, or into the ground by irrigation systems or other methods.

Low pressure/low volume irrigation.--Irrigation systems that apply water directly, or very near to the soil surface, either above the ground or into the air, in discrete drops, continuous drops, small streams, mist, or sprays. These include drip systems, spray systems, jet systems, and bubbler systems. Also referred to as micro or trickle irrigation. The efficiencies of these low pressure irrigation systems range from 75 to 95 percent (Smajstrla and others, 1988), however, the average of 80 percent is commonly used for estimating water requirements. 
Navigational water use.--Water utilized as a means of commercial (and sometimes recreational) transportation. Includes water used to lift a vessel in a lock, or maintain a navigable channel level. Navigational water use is considered a nonconsumptive instream use of water and is generally not measured or accounted for.

Offstream use.--Water withdrawn or diverted from a ground- or surface-water source for public-water supply, industry, irrigation, livestock, thermoelectric power generation, and other uses. Sometimes called off-channel use or withdrawal use.

Once-Through cooling water--Water (fresh or saline) that is withdrawn from a river, stream, or other water body (manmade or natural), or a well, that is passed through a condenser one time, and then returned to the source some distance from the intake (Hughs, 1975, p. 14). Once-through cooling water is used to exchange heat from the steam condenser to the cooling water. This method of cooling is commonly used in power production throughout the southeast, and usually has no consumption involved.

Other water use.--Water used for such purposes as heating and cooling, irrigation of common areas (public areas, highway medians, etc.), lake augmentation, and other nonspecific uses. The water can be obtained from a public supply or be self-supplied.

Outfall.--Refers to the outlet or structure through which reclaimed water or treated effluent is finally discharged to a receiving water body.

Per capita use.--The average amount of water used per person during a standard time period, generally per day. Public supply per capita use refers to the amount of water used (withdrawn) for public supply divided by the population served. Domestic per capita use refers to the amount of water used for domestic (residential) purposes divided by the population served.

Percolation pond.--Refers to a pond (usually manmade) designed to allow treated wastewater effluent to percolate slowly into the ground. The pond acts as a holding facility while gravity allows the water to seep through the soil or other unconsolidated material into the surficial aquifer.

Public supply.--Water withdrawn by public and private water suppliers and delivered to users who do not supply their own water. Water suppliers provide water for a variety of uses, such as domestic, commercial, thermoelectric power, industrial, and public-water use. See also commercial water use, domestic water use, industrial water use, public water use, and other water use.

Public-water use.--Water supplied from a public-water supply and used for such purposes as firefighting, street washing, municipal parks, and swimming pools. Public-water use also includes system water losses (water lost to leakage) and brine water discharged from desalination facilities. Can also be referred to as water-utility use.

Reclaimed wastewater.--Refers to water that has received at least secondary treatment and is reused after being released from a wastewater-treatment facility.

Resident population.--The number of persons who live in a State who consider it their permanent place of residence. College students, military personnel, and inmates of penal institutions are counted as permanent residents. According to this definition, tourist and seasonal or part-time residents are considered nonresident population.

Residential water use.--See domestic water use.

Reuse system.--Means the deliberate application of reclaimed water for a beneficial purpose. Reuse may encompass landscape irrigation (such as golf courses, cemeteries, highway medians, parks, playgrounds, school yards, nurseries, and residential properties), agricultural irrigation (such as food and fruit crops, wholesale nurseries, sod farms and pasture grass), aesthetic uses, ground-water recharge, environmental enhancement of surface water and wetland restoration, fire protection, and other useful purposes.

Return flow.--The water that reaches a ground- or surface-water source after release from the point of use and thus becomes available for further use. 
Saline water.--Water that contains more than $1,000 \mathrm{mg} / \mathrm{L}$ of dissolved solids (Solley and others, 1993).

Self-supplied water.--Water withdrawn from a ground- or surface-water source by a user and not obtained from a public supply.

Septic tank.--Refers to a buried watertight receptacle constructed to promote the separation of solids, grease, and liquid components of wastewater in the absence of oxygen. The liquid fraction from the septic tank is released to a drain or absorption field for further treatment or disposal.

Silviculture.--The forested trees of a region or area. This includes timberland (areas capable of producing 20 cubic feet of industrial wood per acre per year) or woodland (areas incapable of producing 20 cubic feet of industrial wood per acre per year under natural conditions) (Thompson, 1988).

Spray field.--Refers to the land that is the recipient of reclaimed water or treated effluent released on the surface of the ground through a variety of sprinkler heads or nozzles (including overhead systems, center pivot systems, periodic moving systems, and portable or traveling gun systems). See land application.

Sprinkler irrigation.--A pressurized irrigation system where water is distributed through pipes to the field and applied through a variety of sprinkler heads or nozzles. Pressure is used to spread water droplets above the crop canopy to simulate rainfall (Izuno and Haman, 1987). These systems include portable and traveling guns, solid or permanent fixture (overhead or pop ups), center pivots, and periodic moving systems. Also referred as overhead irrigation. The efficiencies of these sprinkler irrigation systems range from 15 to 85 percent (Smajstrla and others, 1988), however, the average of 70 percent is commonly used when estimating water requirements.

Surface-water disposal.--Refers to the release of reclaimed water or treated effluent directly into a surface water body (including marshes or wetlands). This does not include water discharged into ponds for holding or percolation purposes.

Thermoelectric power.--Electrical power generated by using fossil-fuel (coal, oil, or natural gas), geothermal, or nuclear energy.

Thermoelectric power water use.--Water used in the process of the generation of electric power. The majority of water used for this category is for cooling purposes (much of which is used for once-through cooling). Water is also used for boiler makeup or domestic purposes throughout the plant. Boiler makeup water and water used for domestic purposes are generally obtained from a public supplier, however, for facilities located in remote areas, this water can be self-supplied (usually from a well). Cooling water is most often self-supplied, although some smaller facilities use public supplied water for cooling purposes. Water used for thermoelectric power generation purposes is considered an offstream use of water.

Treated (wastewater) effluent.--Refers to water that has received primary, secondary, or advanced treatment and is released from a wastewater facility after treatment.

Wastewater.--A combination of liquid or solid water-carried pollutants from residence, commercial buildings, industrial plants, and institutions needing treatment before reentering the hydrologic cycle. Wastewater may also include any ground or surface water that may have infiltrated or entered into the wastewater return system.

Water transfer.--Artificial conveyance of water from one area to another. This may be referred to as an import or export of water from one basin or county to another.

Withdrawal. Water removed from the ground or diverted from a surface-water source for use. 


\title{
National Water Quality Assessment of the Georgia- Florida Coastal Plain Study Unit-Water Withdrawals and Treated Wastewater Discharges, 1990
}

\author{
By Richard L. Marella and Julia L. Fanning
}

\section{Abstract}

The Georgia-Florida Coastal Plain study unit covers nearly 62,600 square miles along the southeastern United States coast in Georgia and Florida. In 1990, the estimated population of the study unit was 9.3 million, and included all or part of the cities of Atlanta, Jacksonville, Orlando, Tampa, and St. Petersburg. Estimated freshwater withdrawn in the study unit in 1990 was nearly 5,075 million gallons per day. Ground-water accounted for more than 57 percent of the water withdrawn during 1990 and the Floridan aquifer system provided nearly 91 percent of the total ground-water withdrawn. Surface-water accounted for nearly 43 percent of the water withdrawn in the study unit in 1990 with large amounts of withdrawals from the Altamaha River, Hillsborough River, the Ocmulgee River, the Oconee River, the St. Johns River, and the Suwannee River.

Water withdrawn for public supply in the Georgia-Florida Coastal Plain study unit in 1990 totaled 1,139 million gallons per day, of which 83 percent was ground water and 17 percent was surface water. Self-supplied domestic withdrawals in the Georgia-Florida Coastal Plain study unit in 1990 totaled nearly 230 million gallons per day. Ground water supplied over 80 percent of the study units population for drinking water purposes; nearly 5.8 million people were served by public supply and 1.8 million people were served by self-supplied systems. Water withdrawn for self-supplied domestic use in Georgia and Florida is derived almost exclusively from ground water, primarily because this source can provide the quantity and quality of water needed for drinking purposes. Nearly 1.7 million people served by public supply utilized surface water for their drinking water needs.

Water withdrawn for self-supplied commercial-industrial uses in the study unit in 1990 totaled 862 million gallons per day, of which 93 percent was ground water and 7 percent was surface water. Water withdrawn for agriculture purposes in the study unit in 1990 totaled 1,293 million gallons per day, of which 69 percent was ground water and 31 percent was surface water. An estimated 1.254 million acres were irrigated within the study unit during 1990 . Water withdrawn for thermoelectric power generation in the study unit in 1990 totaled 1,552 million gallons per day, of which 99 percent was surface water and 1 percent was ground water. An additional 6,919 million gallons per day of saline surface water were withdrawn for thermoelectric power generation in 1990, solely for cooling purposes.

Treated wastewater discharged within the Georgia-Florida Coastal Plain study unit totaled nearly 1,187 million gallons per day in 1990 . Of the total water discharged, 58 percent was discharged directly into surface water and the remaining 42 percent was discharged to ground water (through drain fields, injection wells, percolation ponds or spray fields). Domestic wastewater facilities discharged in the study unit totaled nearly 789 million gallons per day, industrial wastewater facilities discharged 213 million gallons per day, and releases from septic tanks was estimated at 185 million gallons per day. More than 1.3 million septic tanks were estimated in use within the study unit in 1990. 


\section{INTRODUCTION}

The Georgia-Florida Coastal Plain study unit covers nearly 62,600 square miles $\left(\mathrm{mi}^{2}\right)$ in the Southeastern United States (fig. 1). Located within the study unit are all or part of the following major river basins; Altamaha-St. Marys, Ochlockonee, Ogeechee, Peace-Tampa Bay, St. Johns, Southern Florida (including part of the Kissimmee River basin), and the

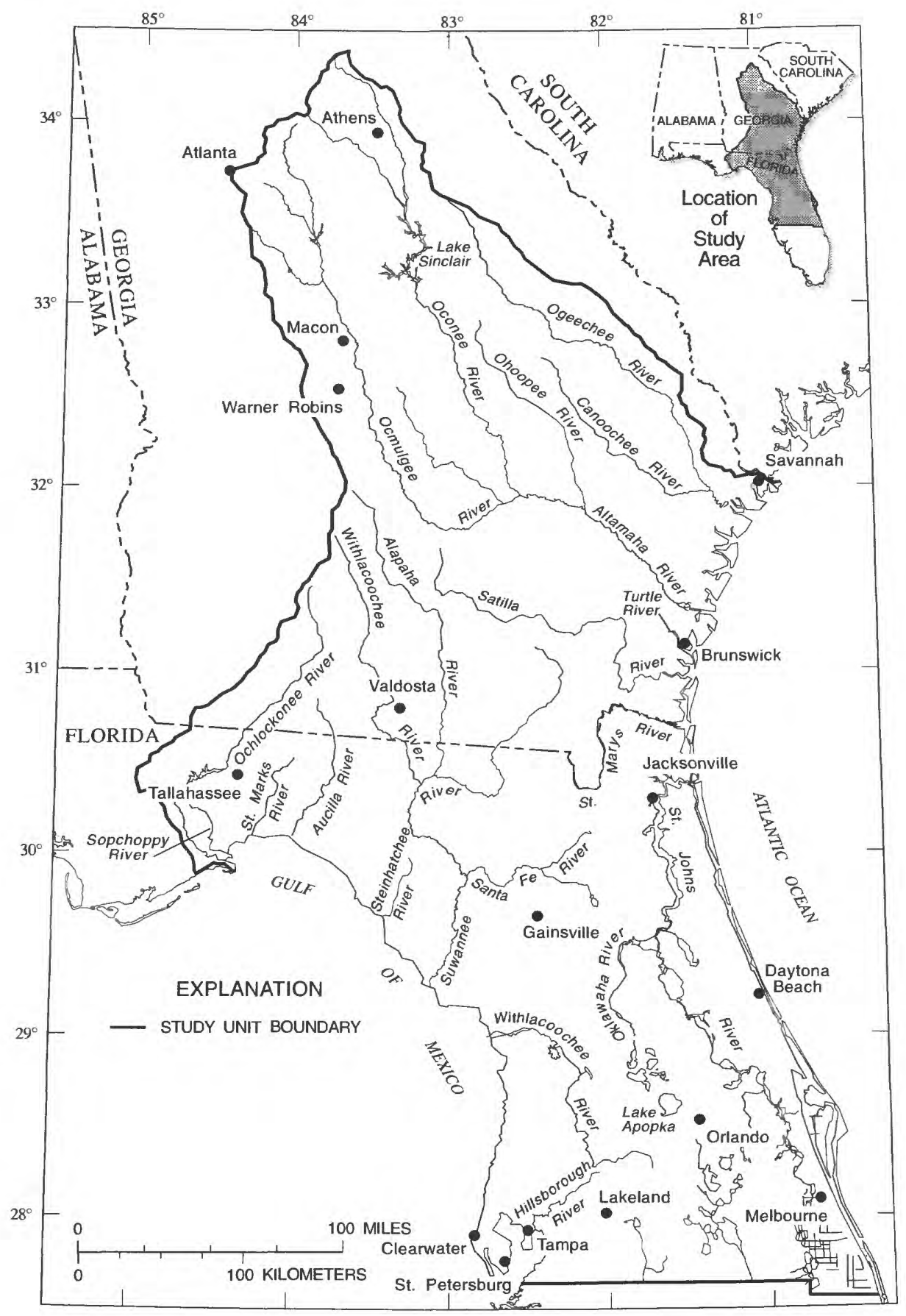

Figure 1. Location of the Georgia-Florida Coastal Plain study unit with major cities and rivers in the study unit. 
Suwannee. The study unit is located in the Piedmont and Coastal Plain physiographic provinces, and about 90 percent of the unit is underlain by the Floridan aquifer system (fig. 2). Forest lands comprise the largest percentage of area covered (48 percent) in the study unit. A large percentage of forest lands are planted and harvested (silviculture) for pulp and paper production. Other land uses include agriculture

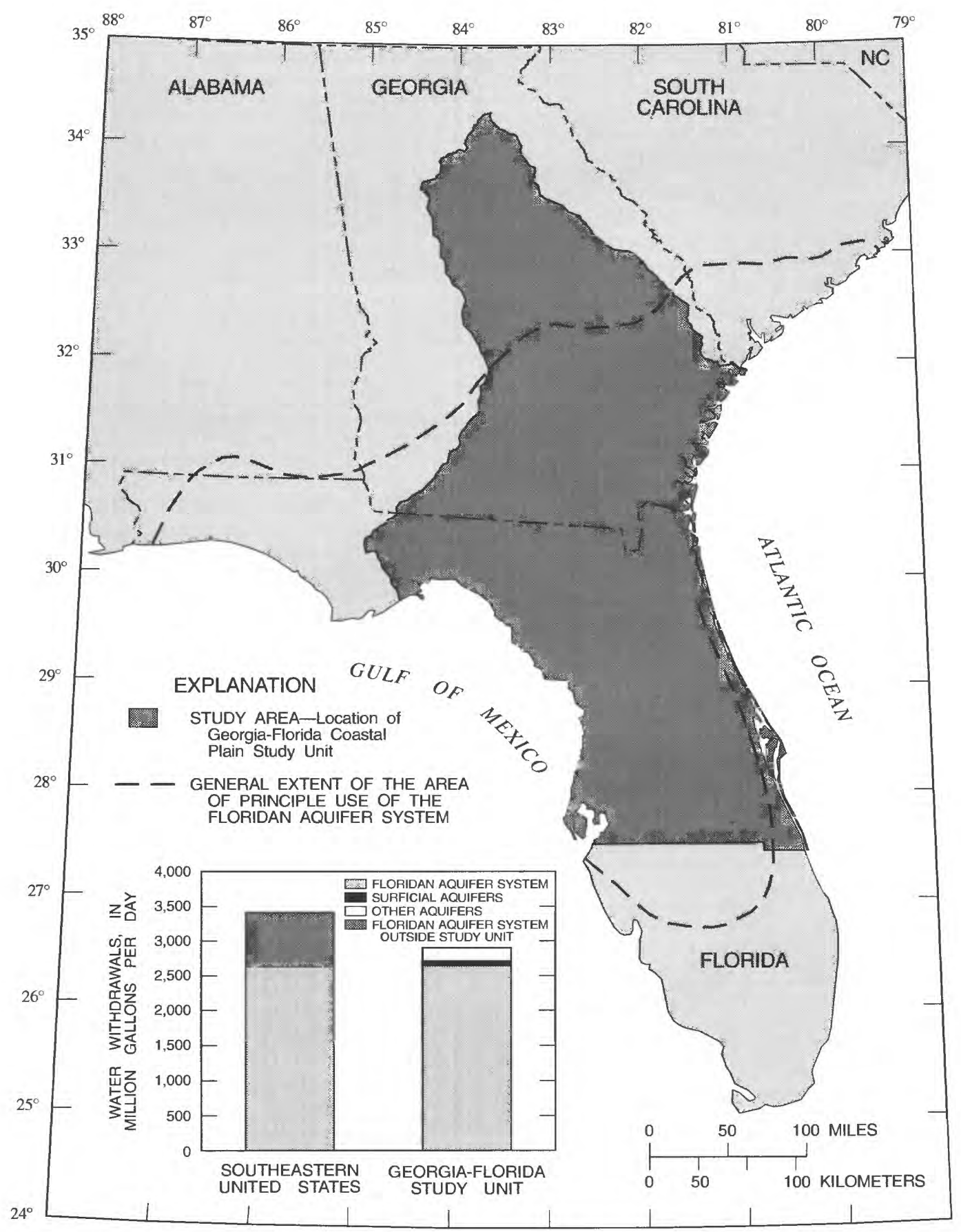

Figure 2. General location of and ground-water withdrawals from principal aquifers in the Georgia-Florida Coastal Plain study unit, 1990. 
( 25 percent), wetlands ( 16 percent), urban (4 percent), water areas ( 3 percent) and rangeland and barrenland comprise the remaining 4 percent. Citrus and vegetables (truck crops) were the major crops grown and irrigated within the study unit (Berndt and others, in press), with most of the acreage occurring in the extreme southern part of the study unit.

The total population in the Georgia-Florida Coastal Plain study unit for 1990 was estimated at 9.3 million. Located within the study unit are all or part of 4 of the 50 most populated metropolitan statistical accounting areas (MSA) in the nation in 1990. These include the Tampa-St. Petersburg-Clearwater MSA (2.068 million people), Orlando MSA (1.073 million people), the Jacksonville MSA (0.907 million people), and part of the Atlanta MSA (2.834 million) (U.S. Bureau of Census, 1991a, p. 33). Other population centers within the study unit include Daytona Beach, Gainesville, and Tallahassee in Florida and Macon, Savannah (partially) and Valdosta in Georgia. Economic activities include agriculture, commercial services, lumber and food processing, manufacturing (pulp and paper, textiles, electronics), mining (limerock and phosphate), transportation, and tourism.

The U.S. Geological Survey began implementation of a full-scale National Water-Quality Assessment (NAWQA) program in 1991. The overall goals of the program are to, (1) describe the status and trends in the quality of a large, representative part of the Nation's surface- and ground water resources, (2) define longterm trends in water quality, and (3) identify the natural and human factors that affect water quality (Hirsch and others, 1988). The program consist of 60 study units nationally that contain segments of most major river basins or aquifer systems. The study units were delineated to incorporate $60-70$ percent of the water use and population served by public water supply in the nation. Because the Georgia-Florida Coastal Plain study unit is heavily dependent upon the water resources of the area, the collection and compilation of water-use data is important. Information provided in this report aid scientists to determine some of the factors and trends that affect the water quality in this part of the United States.

\section{Purpose and Scope}

The purpose of this report is to present the most recent (1990) water-use values for the Georgia-Florida Coastal Plain study unit. An inventory of the quantity of freshwater withdrawn (fresh), category of use, and the locations (State, river basin, and county) of water used in the Georgia-Florida Coastal Plain study unit during 1990 are provided. Primary sources of water are identified as well as baseline computations for future trends in water withdrawals within the study unit. Additional data are presented for wastewater discharge including the amount of wastewater discharged for 1990, along with the location and the type of discharge.

Data on freshwater withdrawals in the Georgia-Florida Coastal Plain study unit are presented for each of the following categories: public supply, self-supplied domestic, self-supplied commercialindustrial (including mining uses), agriculture (including irrigation, livestock and fish farming uses), and thermoelectric power generation. Water-use data for the study unit were compiled by county. For counties that are partially within the study unit, data are presented only for that part of the county that lies within the study unit. The water-use data presented in this report are predominantly for 1990 , with some water-use data reported for 1980, 1985 and 1987. Information concerning instream (nonwithdrawal) water use, such as navigation, water-based recreation, propagation of fish and wildlife, dilution and conveyance of liquid or solid wastes, and hydroelectric power generation are not included.

Water-use estimates are expressed in million gallons per day (Mgal/d) and are the average daily quantities derived from annual data. The tables in this report show values in million gallons per day and are reported to two decimal places or to 10,000 gallons per day. Water-use values in the text, however, are rounded to whole numbers.

\section{Previous Investigations}

Because the Georgia-Florida Coastal Plain is a newly defined study area, no previous water-use reports have been completed; however, some wateruse data for 1985 were reported for the study unit by Kantrowitz (1991). The totals compiled in the Kantrowitz report differ from those in this report because the study unit area was increased when the 
boundaries were redefined in early 1993. Water-use reports for Florida (Leach, 1983; Marella, 1988) and Georgia (Pierce and others, 1982; Turlington and others, 1987) that detail water use on a county and category level were published for 1980 and 1985 . Although these reports contain water-use data by category and county for their respective State, they do not specifically aggregate the water-use data for the Georgia-Florida Coastal Plain study unit for those years. Based on the redefined study unit boundaries, the data in these reports were used to recalculate the study unit totals for 1980 and 1985.

\section{Data Sources and Reliability}

As part of the U.S. Geological Survey (USGS) National Water-Use Information Program, water-use data are collected and compiled for each State every 5 years (Solley and others, 1988). Water-use values are reported in each State by category, county, hydrologic unit (surface-water basin), and aquifer. Data used for this report were compiled by each State as part of the 1990 National Water-Use Information Program. Water-use data for Florida in 1990 were collected through an ongoing cooperative effort between the Florida Department of Environmental Protection (FDEP) and the USGS and published by Marella (1992b). Most of the data for Florida were obtained from the FDEP and the five water management districts (Northwest Florida, St. Johns River, South Florida, Southwest Florida, and the Suwannee River). Water-use data for Georgia in 1990 were collected through an ongoing cooperative effort among the Georgia Department of Natural Resources, Environmental Protection Division, Georgia Geologic Survey and the USGS and published by Fanning and others (1992). The reports from these agencies provided the data necessary for compiling the water-use values for the Georgia-Florida Coastal Plain study unit.

The accuracy of the water-use data by category presented in this report varies. For example, withdrawal data for the categories of public-supply, commercial, industrial, mining, and power generation are considered more accurate because most systems or facilities in Georgia and Florida meter their usage. Data for the categories of agriculture and self-supplied domestic are less accurate because they are most often estimated. Agricultural withdrawals are estimated from information provided by the County Extension Office or other State agencies and multiplied by a crop coefficient which is based on rainfall and growing seasons. Self-supplied domestic withdrawals are estimated by multiplying the population not served from public supply by a calculated or estimated per capita value. Wastewater discharge values are considered accurate, as most facilities are required to record their untreated water inflows or treated water outflows.

\section{Description of Study Unit}

The Georgia-Florida Coastal Plain study unit covers a large part of two States and seven major river basins (hydrologic units) in central and southeastern Georgia and central and northern Florida The study unit includes all or part of 135 counties in Georgia (95) and Florida (40) (fig. 3). In Florida, the central, north-central, western, and northern Gulf Coast part of the study unit is rural and predominantly comprised of agricultural cropland (including pasture land) forest, and wetlands. Along the east coast, across central Florida, and around Tampa Bay on the west coast, the study unit is highly urbanized. In Georgia, the eastern part of the study unit is predominately forest and wetlands with a few urban areas along the coast whereas the northwestern part of the study unit is highly urbanized (Atlanta) and south-central Georgia is mostly agricultural cropland and forest. The total population in the study unit in 1990 was estimated at nearly 9.3 million. An estimated 81 percent of the population (7.5 million) relied on public-supply water systems for their drinking water needs. The remaining 19 percent ( 1.8 million) are served by small public suppliers not inventoried or are self-supplied by individual systems.

Georgia $\left(31,860 \mathrm{mi}^{2}\right)$ and Florida $\left(29,700 \mathrm{mi}^{2}\right)$ accounted for roughly equal amounts of land area in the study unit (52 percent and 48 percent, respectively). However, in 1990 more than 70 percent of the population lived in Florida (6.532 million), while the remaining 30 percent ( 2.735 million) lived in Georgia. In Florida, the more populated cities within the study unit for 1990 include Jacksonville (0.635 million), Tampa (0.280 million), St. Petersburg ( 0.239 million), Orlando (0.165 million), Tallahassee (0.125 million), Clearwater (0.099 million), Gainesville (0.085 million) and Lakeland (0.071 million) (University of Florida, 1991, p. 44) (fig. 1). In Georgia, some of the more populated cities within the study unit for 1990 include Macon (0.107 million), Athens (0.046 million), Warner Robins (0.044 million), and Valdosta (0.040 million) (Akioka, 1992, p. 12). Only parts of the cities of Atlanta and Savannah are within the study unit, and the exact population of these cities within the study unit in unknown. 


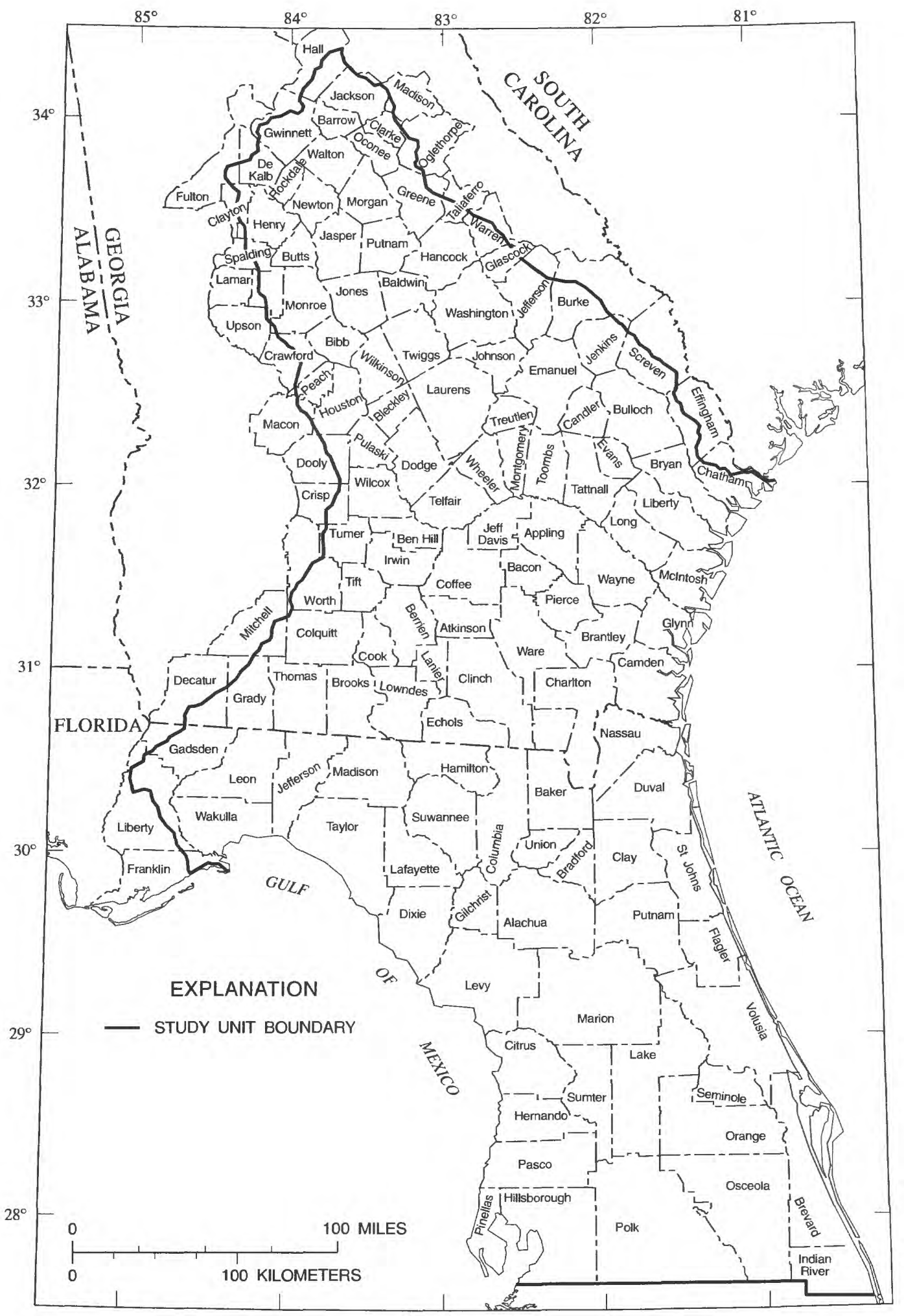

Figure 3. Locations of counties in the Georgia-Florida Coastal Plain study unit. 


\section{WATER WITHDRAWALS IN THE GEORGIA-FLORIDA COASTAL PLAIN STUDY UNIT}

Estimated freshwater withdrawn in the GeorgiaFlorida Coastal Plain study unit in 1990 was nearly $5,075 \mathrm{Mgal} / \mathrm{d}$. An additional $6,998 \mathrm{Mgal} / \mathrm{d}$ of saline water was withdrawn in the study unit in 1990. Florida accounted for $3,060 \mathrm{Mgal} / \mathrm{d}$ ( 60 percent) of the freshwater withdrawn and Georgia the remaining $2,015 \mathrm{Mgal} / \mathrm{d}$ (40 percent). The total freshwater withdrawn in the Florida part of the study unit accounted for nearly 41 percent of the State's 1990 freshwater use (7,532 Mgal/d) (Marella, 1992b, p. 6) The total freshwater withdrawn in the Georgia part of the study unit accounted for nearly 38 percent of the 1990 freshwater use (5,353 Mgal/d) (Fanning and others, 1992, p. 5) for the State. Freshwater withdrawn in the study unit increased 3 percent from 1985 to 1990 , but decreased nearly 3 percent from 1980 to 1990 . Of the freshwater withdrawn in 1990, approximately 28 percent $(1,410 \mathrm{Mgal} / \mathrm{d})$ was consumed and 72 percent was returned to ground- and surface-water sources for possible reuse. Less than 0.1 percent of the saline withdrawals were consumed in 1990.

\section{Source of Withdrawals}

Ground water is the primary source of freshwater in the study unit, accounting for more than 57 percent of the water withdrawn in 1990 . Florida accounted for 2,292 Mgal/d (79 percent) of the ground-water withdrawn and Georgia $596 \mathrm{Mgal} / \mathrm{d}$ (21 percent). Surface water accounted for 43 percent of the freshwater withdrawn in 1990. Georgia accounted for $1,418 \mathrm{Mgal} / \mathrm{d}$ (65 percent) of the surface water withdrawn and Florida $769 \mathrm{Mgal} / \mathrm{d}$ (35 percent). Additionally, $115 \mathrm{Mgal} / \mathrm{d}$ of reclaimed wastewater water was used throughout the study unit during 1990.

\section{Ground Water}

In 1990, ground water withdrawn in the study unit totaled 2,888 Mgal/d (table 1). This represents an increase in ground water withdrawals of 4 percent and 13 percent since 1985 and 1980, respectively. Six counties within the study unit (Brevard, Duval, Hillsborough, Orange, Pasco, and Polk) withdrew more than $100 \mathrm{Mgal} / \mathrm{d}$ from ground water sources in 1990 (fig. 4) with the largest withdrawal in Polk County (354 Mgal/d). Ground water supplied drinking-water for nearly 77 percent ( 5.8 million) of the population served by public supply and 100 percent (1.8 million) of the self-supplied population.

The Florida aquifer system, which underlies about 90 percent of the study unit, provided nearly 91 percent $(2,630 \mathrm{Mgal} / \mathrm{d})$ of the ground-water withdrawn in the Georgia-Florida Coastal Plain study unit in 1990 (fig. 2). More than 77 percent of the total water withdrawn in 1990 from the Floridan aquifer system in the southeastern United States was withdrawn in the study unit in 1990. An estimated total of $3,415 \mathrm{Mgal} / \mathrm{d}$ of water was withdrawn from the Floridan aquifer system in 1990 in Alabama, Florida, Georgia, and South Carolina (Marilee Horn, U.S.

Table 1. Freshwater withdrawals and reclaimed wastewater by principal water-use category in the GeorgiaFlorida Coastal Plain study unit, 1990

[Withdrawals are in million gallons per day; self-supplied commercial-industrial includes withdrawals for mining purposes; agriculture includes withdrawals for irrigation, livestock, and fish farming purposes]

\begin{tabular}{|c|c|c|c|c|}
\hline \multirow{2}{*}{ Category } & \multicolumn{3}{|c|}{ Freshwater withdrawals } & \multirow{2}{*}{$\begin{array}{c}\text { Reclaimed } \\
\text { wastewate } \\
\text { Total use }\end{array}$} \\
\hline & Ground water & Surface water & Total & \\
\hline Public supply & 947.41 & 191.39 & $1,138.80$ & 0.00 \\
\hline Self-supplied domestic & 229.51 & 0.00 & 229.51 & 0.00 \\
\hline Self-supplied commercial-industrial & 801.94 & 60.39 & 862.33 & 0.00 \\
\hline Agriculture & 892.48 & 400.95 & $1,293.43$ & 111.18 \\
\hline Thermoelectric power generation & 16.55 & 1.534 .69 & $1,551.24$ & 4.20 \\
\hline Totals & $2,887.89$ & $2,187.42$ & $5,075.31$ & 115.38 \\
\hline
\end{tabular}




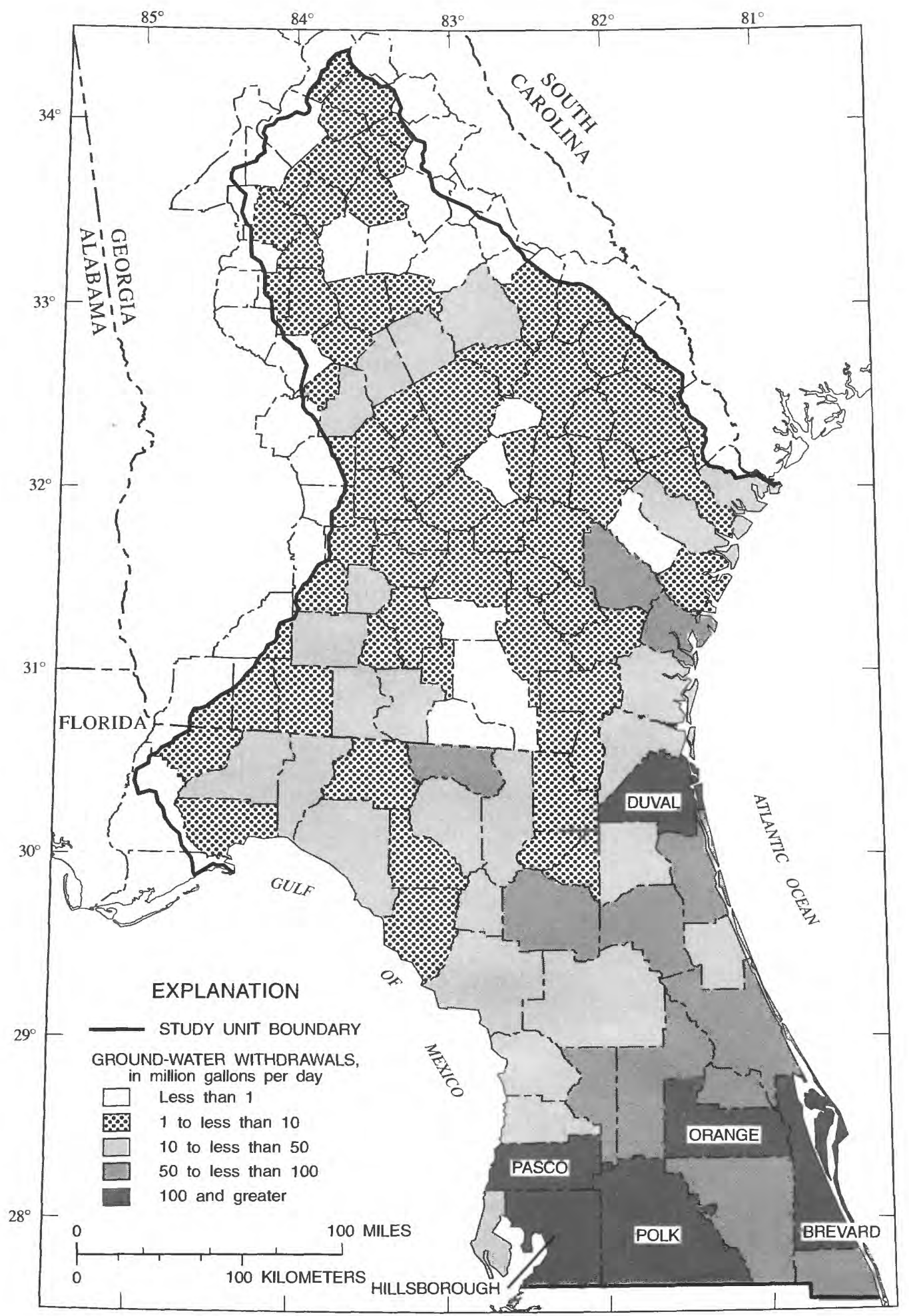

Figure 4. Ground-water withdrawals by county in the Georgia-Florida Coastal Plain study unit, 1990. 
Geological Survey, written commun., March 1993). Within the study unit, the Floridan aquifer system supplied the majority of ground water for all water-use categories (public supply, self-supplied domestic, selfsupplied commercial-industrial, agriculture and thermoelectric power generation) within the study unit (table 2).

Several other aquifers in the study unit are tapped for water supply needs. Surficial aquifers overlying the Floridan aquifer system in many parts of the study unit supplied about 3 percent $(85 \mathrm{Mgal} / \mathrm{d})$ of the ground-water withdrawn in 1990. These unnamed surficial aquifers are utilized for small self-supplied domestic wells in areas where the Floridan aquifer system is too deep to tap, or where the water of the Floridan aquifer system is nonpotable. The Intermediate aquifer system is present primarily in southwest Florida and along the eastern coast of Florida (Vecchioli and Foose, 1985). The intermediate aquifer system in Florida and the Upper and Lower Brunswick aquifers in Georgia are utilized in areas where the water quality of the Floridan aquifer system is nonpotable. The Claiborne, Cretaceous, and Crystalline Rock aquifers are located along the northern and western boundary of the study unit in Georgia (primarily where the Floridan aquifer system is not present), and are utilized to a small degree (Clarke and Pierce, 1985). Withdrawals from the Intermediate aquifer system, the Upper and Lower Brunswick aquifers, along with Claiborne, Cretaceous, and Crystalline Rock aquifers are combined as other aquifers (table 2). These aquifers combined supplied about 6 percent (173 Mgal/d) of the ground-water withdrawn in the study unit in 1990 .

\section{Surface Water}

In 1990, surface water (fresh) withdrawn in the study unit totaled 2,187 Mgal/d (table 1). This represents a 2 percent increase from the surface water withdrawn in 1985, but an 18 percent decrease from the surface water withdrawn in 1980. Most of the decrease occurred in the usage for thermoelectric power generation, as several plants changed from once-through cooling to using cooling ponds or owers. Four counties within the study unit (Indian River, Suwannee, Putnam, and Volusia) withdrew more than $100 \mathrm{Mgal} / \mathrm{d}$ from surface water sources in 1990 (fig. 5) with the largest amount withdrawn in Putnam County Georgia (1,047 Mgal/d). Surface water supplied drinking water for 23 percent (1.7 million) of the population served by public-supply.

Large amounts of surface water were withdrawn from most rivers in the study unit during 1990 . Withdrawals from the Altamaha, Hillsborough, Ocmulgee, Oconee, St. Johns, and Suwannee Rivers for public supply, commercial, industrial and thermoelectric power generation totaled about $1,630 \mathrm{Mgal} / \mathrm{d}$ in 1990. Nearly 100 percent of the surface water withdrawn from these rivers for thermoelectric power

Table 2. Ground-water withdrawals by principal aquifer in the Georgia-Florida Coastal Plain study unit, 1990

\begin{tabular}{|c|c|c|c|c|}
\hline \multirow[b]{2}{*}{ Category of use } & \multicolumn{4}{|c|}{ Withdrawals by source (in million gallons per day) } \\
\hline & $\begin{array}{c}\text { Floridan aquifer } \\
\text { system }\end{array}$ & Surficial aquifers & $\begin{array}{l}\text { Other (1) } \\
\text { aquifers }\end{array}$ & Total withdrawn \\
\hline Public supply & 893.85 & 19.70 & 33.86 & 947.41 \\
\hline Self-supplied domestic & 150.71 & 47.25 & 31.55 & 229.51 \\
\hline Self-supplied commercial-industrial & 742.15 & 1.46 & 58.33 & 801.94 \\
\hline Agriculture & 826.83 & 16.64 & 49.01 & 892.48 \\
\hline Thermoelectric power generation & 16.24 & 0.31 & 0.00 & 16.55 \\
\hline Totals & $2,629.78$ & 85.36 & 172.75 & $2,887.89$ \\
\hline
\end{tabular}

\footnotetext{
(1) Other aquifers include the Claiborne, Cretaceous, Intermediate, and the Upper and Lower Brunswick as defined in Clarke and Pierce, 1985, and Vecchioli and Foose, 1985.
} 


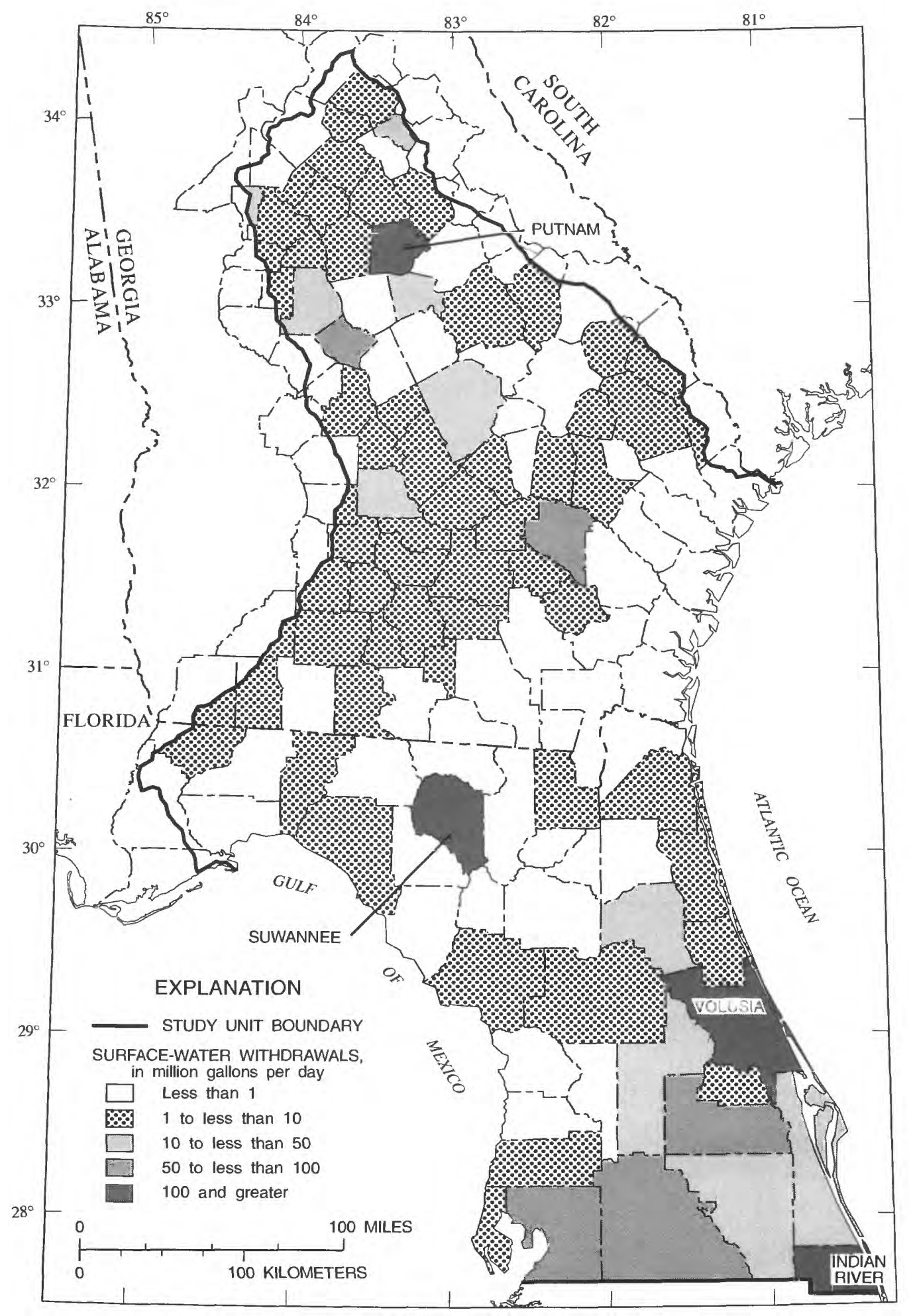

Figure 5. Surface-water withdrawals by county in the Georgia-Florida Coastal Plain study unit, 1990. 
generation is returned. Withdrawals from these rivers specifically for agricultural needs was undetermined.

Most of the withdrawals for agricultural needs as well as the remaining surface water withdrawn in the study unit for public supply, commercial, and industrial needs were obtained from other rivers, unnamed canals or ditches, local lakes or ponds, or small creeks or tributaries. The amount of water withdrawn from each major river basin are presented in a following section of this report.

Saline surface water withdrawn in the study unit during 1990 totaled $6,998 \mathrm{Mgal} / \mathrm{d}$. A large percentage of the saline water was withdrawn from Tampa Bay (37 percent) and the Gulf of Mexico (20 percent). Other saline water sources include the Indian River, St. Johns River, St. Marks River, and the Turtle River, as well as other coastal water bodies. Most of these rivers are fresh water rivers, however in the areas were these rivers meet the coast, they are tidally influenced and are most often a mix of fresh and saline waters. Because the percentage of fresh and saline water changes often, but is predominately saline, the withdrawals in these areas are considered saline. All of the saline water withdrawn for once-through cooling is returned to the source.

\section{Water Withdrawals by Category}

Water-use data in 1990 were collected and compiled for the following categories: public supply, self-supplied domestic, self-supplied commercial- industrial, agriculture, and thermoelectric power generation. Thermoelectric power generation accounted for the largest amount of surface-water withdrawn in the Georgia-Florida Coastal Plain study unit in 1990 (70 percent) followed by agriculture (18 percent), public supply ( 9 percent), and self-supplied commercialindustrial (3 percent) (fig. 6). Public supply accounted for the largest amount ( 33 percent) of the ground-water withdrawn, followed by agriculture (31 percent), self-supplied commercial-industrial (28 percent), self-supplied domestic ( 7.5 percent), and thermoelectric power generation ( 0.5 percent) (fig. 6). Between 1985 and 1990, water withdrawals increased for public supply, self-supplied domestic use, and agriculture; withdrawals decreased for thermoelectric power generation, and self-supplied commercial-industrial purposes (fig. 7 and table 3 ).

\section{Public Supply}

Water withdrawn for public supply in the Georgia-Florida Coastal Plain study unit in 1990 totaled about 1,139 Mgal/d (table 1), of which 83 percent was ground water and 17 percent was surface water (fig. 6). Withdrawals for public supply within the study unit increased 18 percent from 1985 to 1990 and 49 percent from 1980 to 1990 (fig. 7). These increases are primarily the result of an increase in resident, tourist, and seasonal populations. The expansion of public-supply utilities into unserviced areas around larger cities and the conversion of several industrial facilities from self-supplied systems to

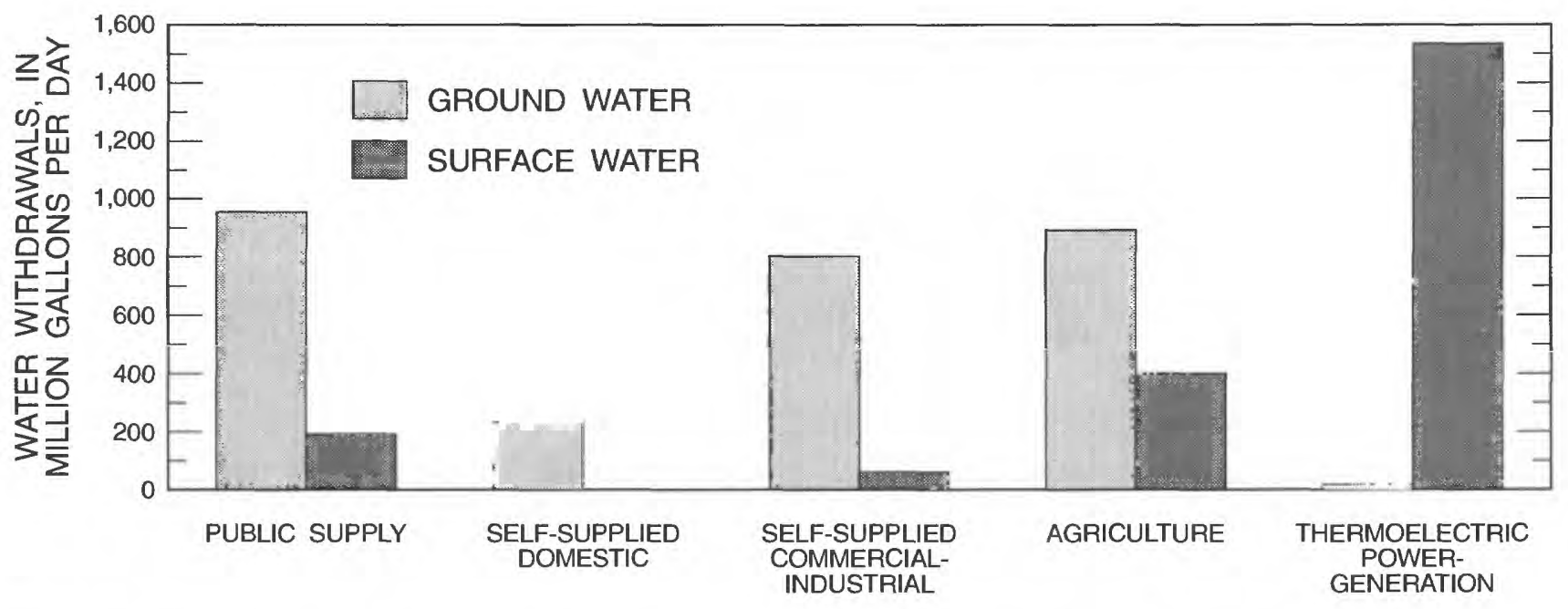

Figure 6. Ground- and surface-water withdrawals by water-use categories in the Georgia-Florida Coastal Plain study unit, 1990. 


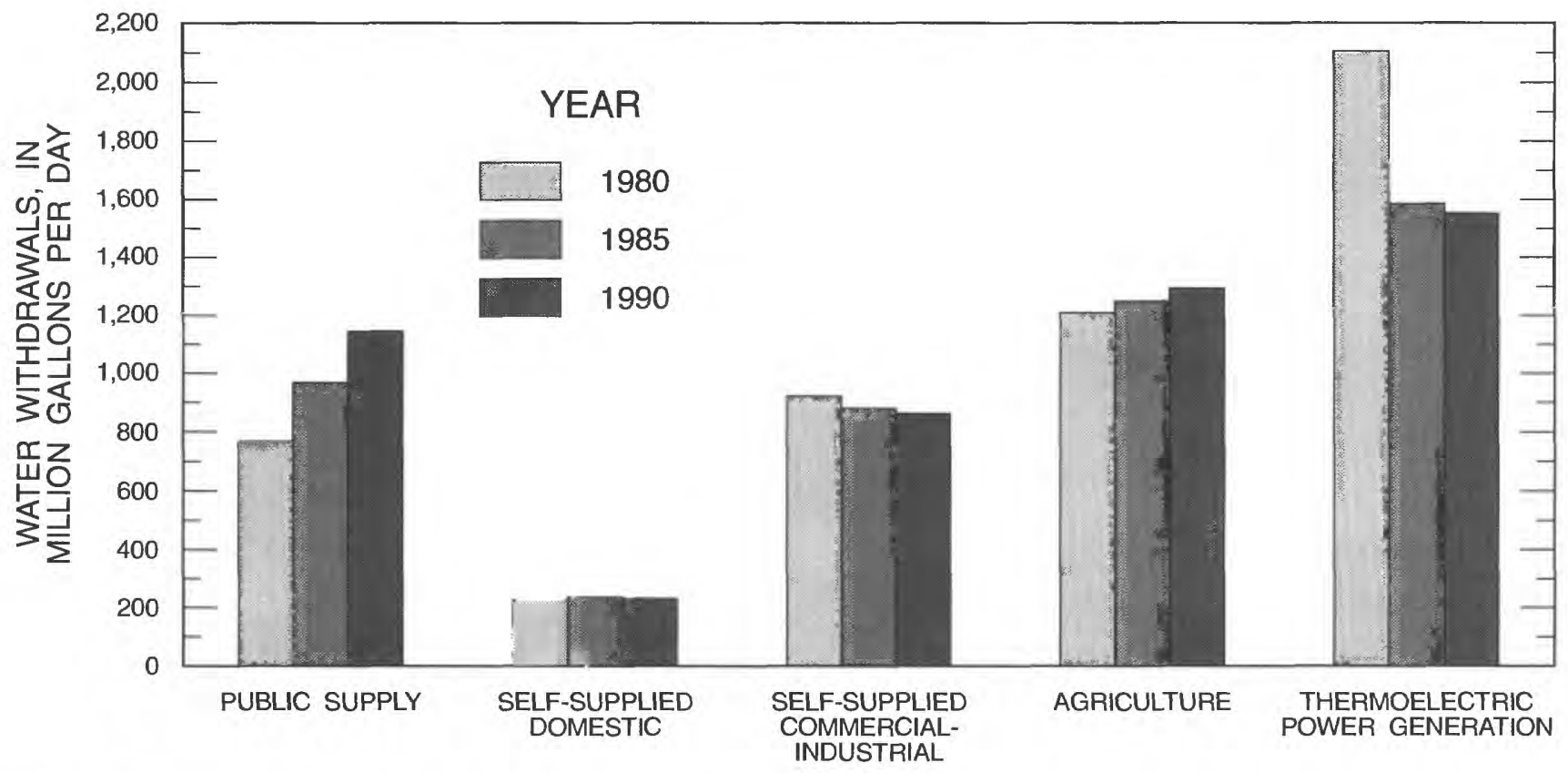

Figure 7. Freshwater withdrawals by water-use category in the Georgia-Florida Coastal Plain study unit for 1980,1985 , and 1990.

public supply purchasers have contributed to the increase in withdrawals (Marella, 1992a). Florida accounted for 79 percent and Georgia 21 percent of the water withdrawn for public supply in the study unit during 1990.

Nearly 740 public supply utilities were inventoried in the study area for 1990 . Of this total, 476 were located in Florida (app. 1, table A) and 265 were located in Georgia (app. 1, table B). These systems include facilities that served 400 people or more or had a withdrawal of $0.01 \mathrm{Mgal} / \mathrm{d}$ or more during 1990. By far, the majority of these systems (85 percent) tap the Floridan aquifer system, while only 1 percent tap surficial aquifers, and 10 percent tap the other aquifers within the study unit. Most of these utilities or water systems have multiple well fields located throughout their service areas. The remaining 4 percent of the systems inventoried for 1990 withdrew surface water, and several of these supplement their surface-water withdrawals with ground water. The municipal water systems for the cities of Tampa ( $81 \mathrm{Mgal} / \mathrm{d}$ ), Orlando ( $79 \mathrm{Mgal} / \mathrm{d}$ ), and Jacksonville (70 Mgal/d) were the largest public suppliers in the study unit during 1990. Consequently, the counties associated with these cities (Hillsborough, Orange, and Duval, respectively) withdrew the largest amount of water during 1990 (table 4). The general location of the 23 public-supply utilities that withdrew more than $10 \mathrm{Mgal} / \mathrm{d}$ during 1990 is shown in figure 8 .

Ground water is the primary source for publicsupply water in central, northern, and western Florida as well as southeastern and south-central Georgia because it is readily available, is of good quality in most areas, usually requires very little treatment before distribution, and generally is cheaper to produce than surface water (Marella, 1992a). In 1990, ground water withdrawn for public supply in the study unit totaled $947 \mathrm{Mgal} / \mathrm{d}$ (table 1 and fig. 6) and was the source of water for most of the water suppliers. Nearly 94 percent $(893 \mathrm{Mgal} / \mathrm{d}$ ) of the ground-water withdrawn for public supply in the study unit in 1990 was supplied by the Floridan aquifer system (table 2). The remaining ground-water was withdrawn from surficial aquifers (20 Mgal/d), and other aquifers (34 Mgal/d) (table 2). Ground water accounted for 89 percent (150 Mgal/d) of the increase in public supply withdrawals between 1985 and 1990 and 97 percent (325 Mgal/d) of the increase between 1980 and 1990 (table 3).

A small amount of ground water withdrawn for public supply in the study unit for 1990 was too saline for immediate potable purposes and required treatment to meet drinking water standards (Florida Department of Environmental Regulation, 1990). These withdrawals occurred in Brevard, Indian River and Volusia 


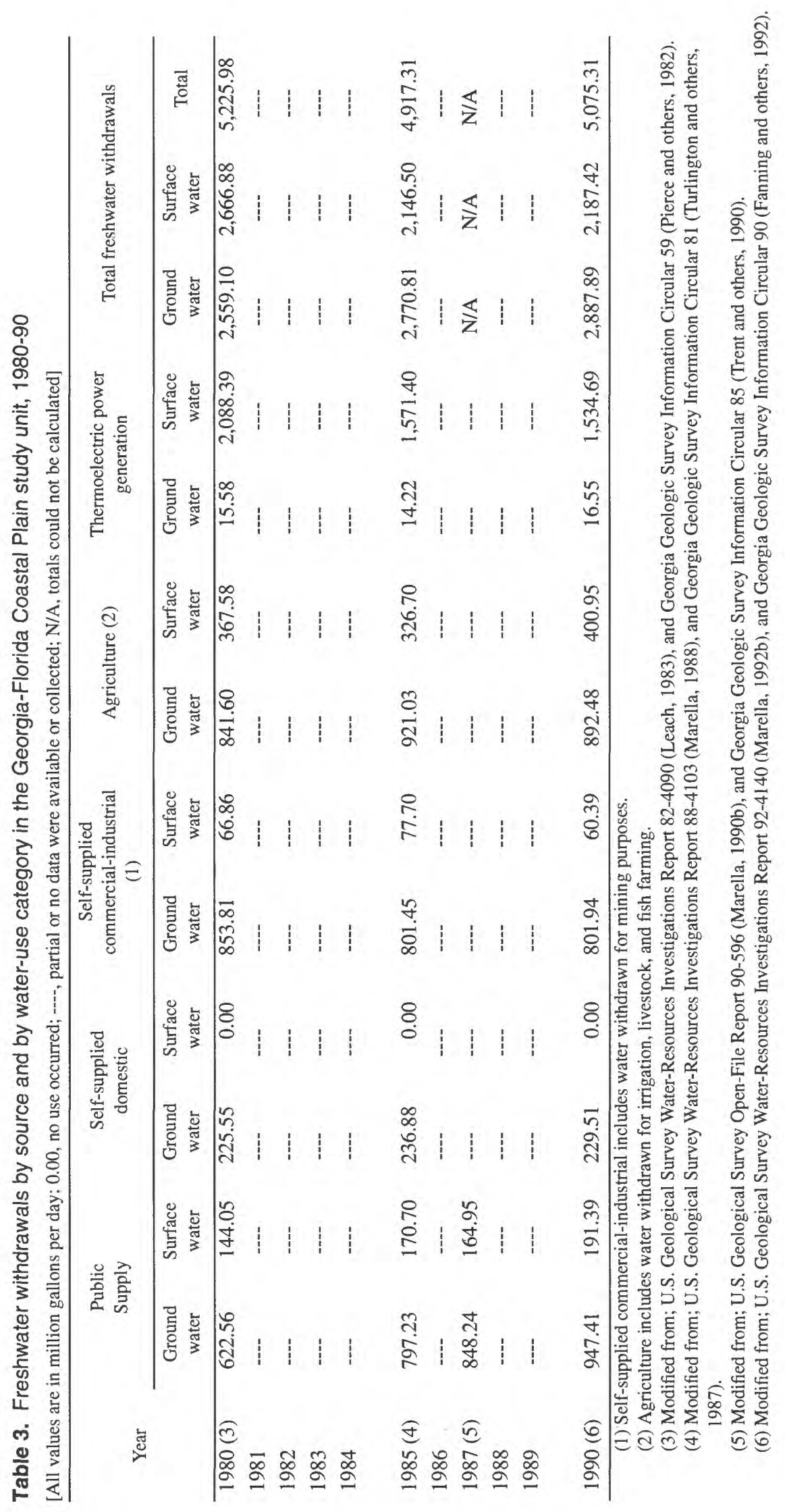




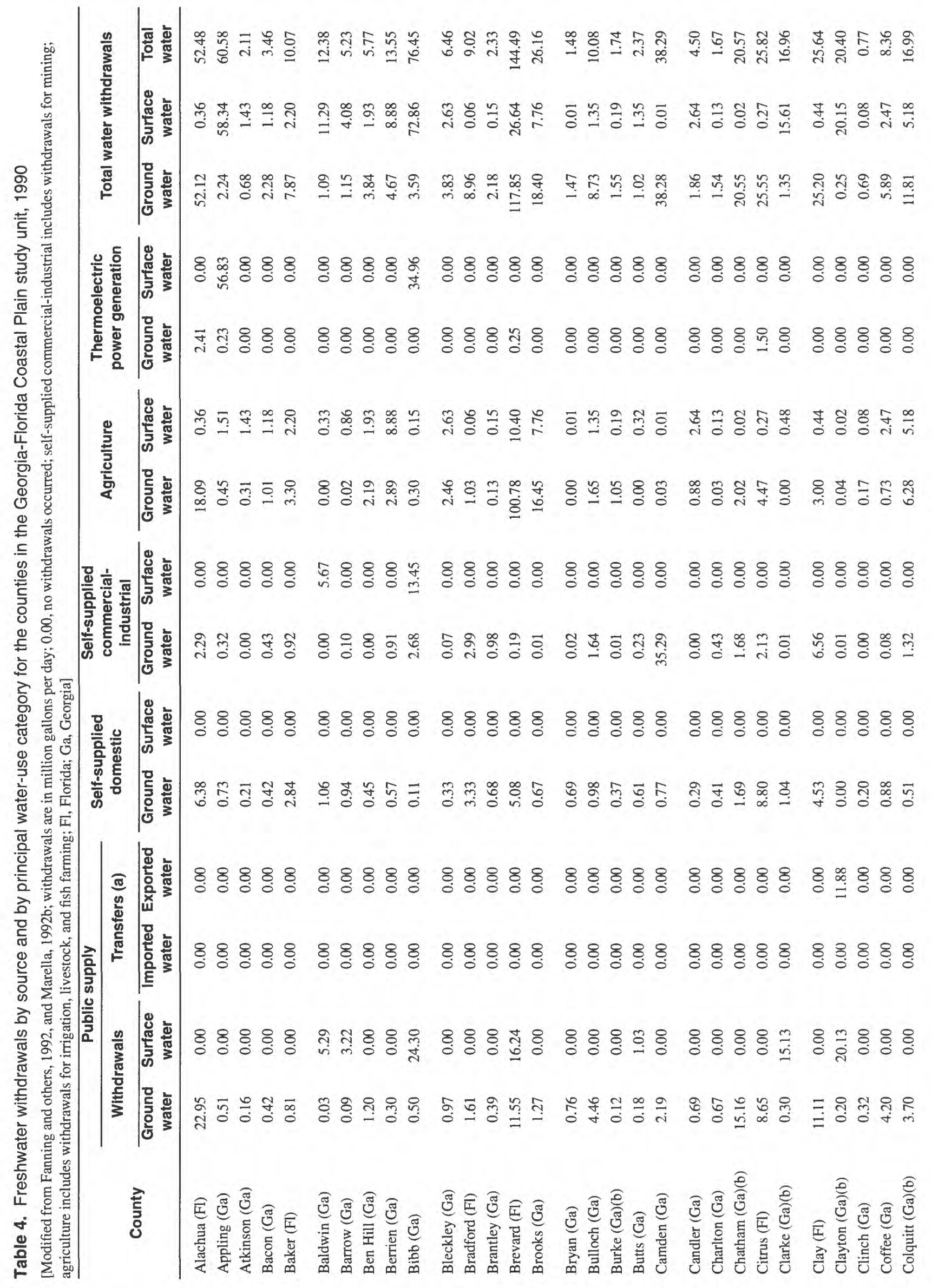




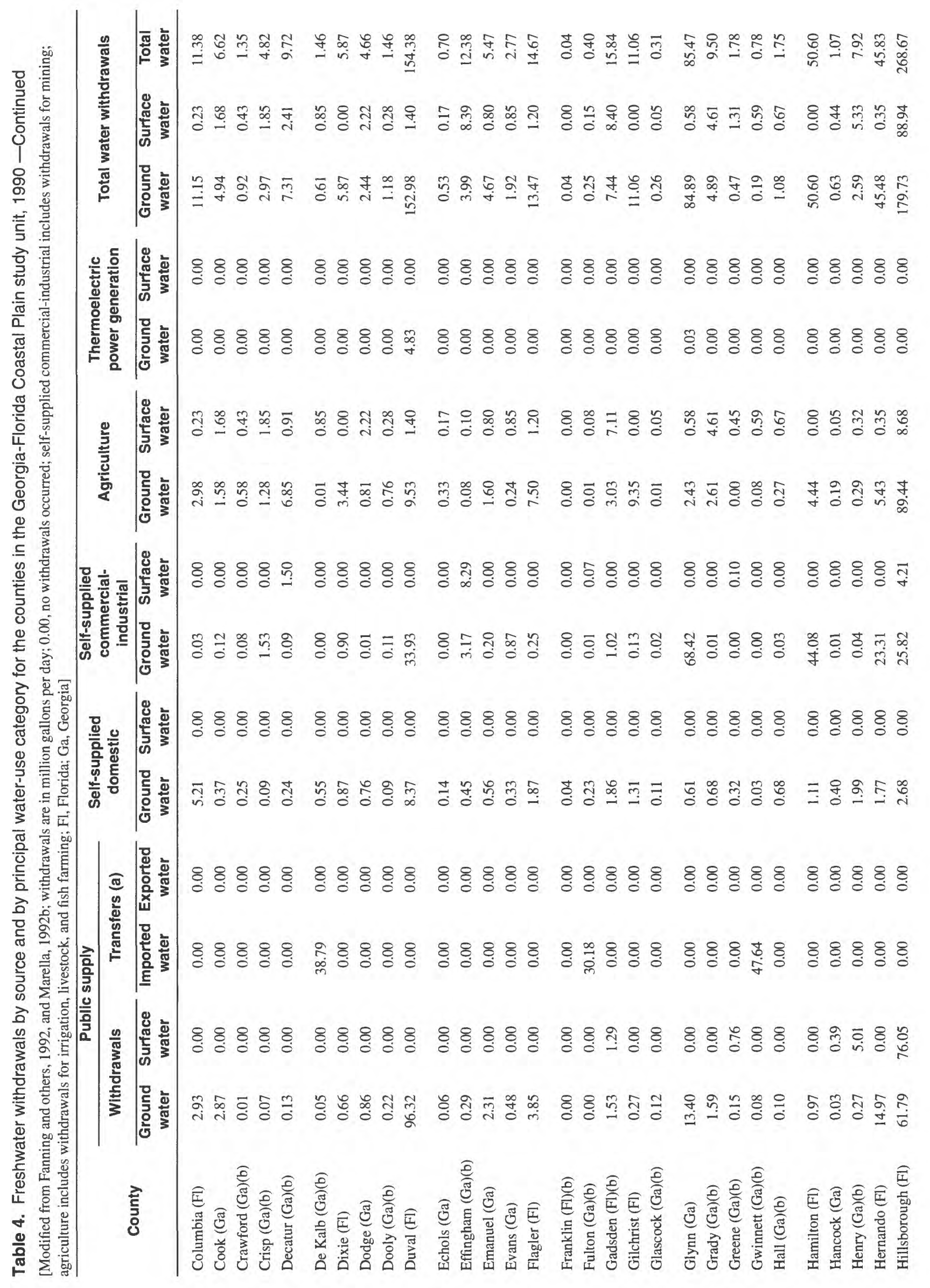




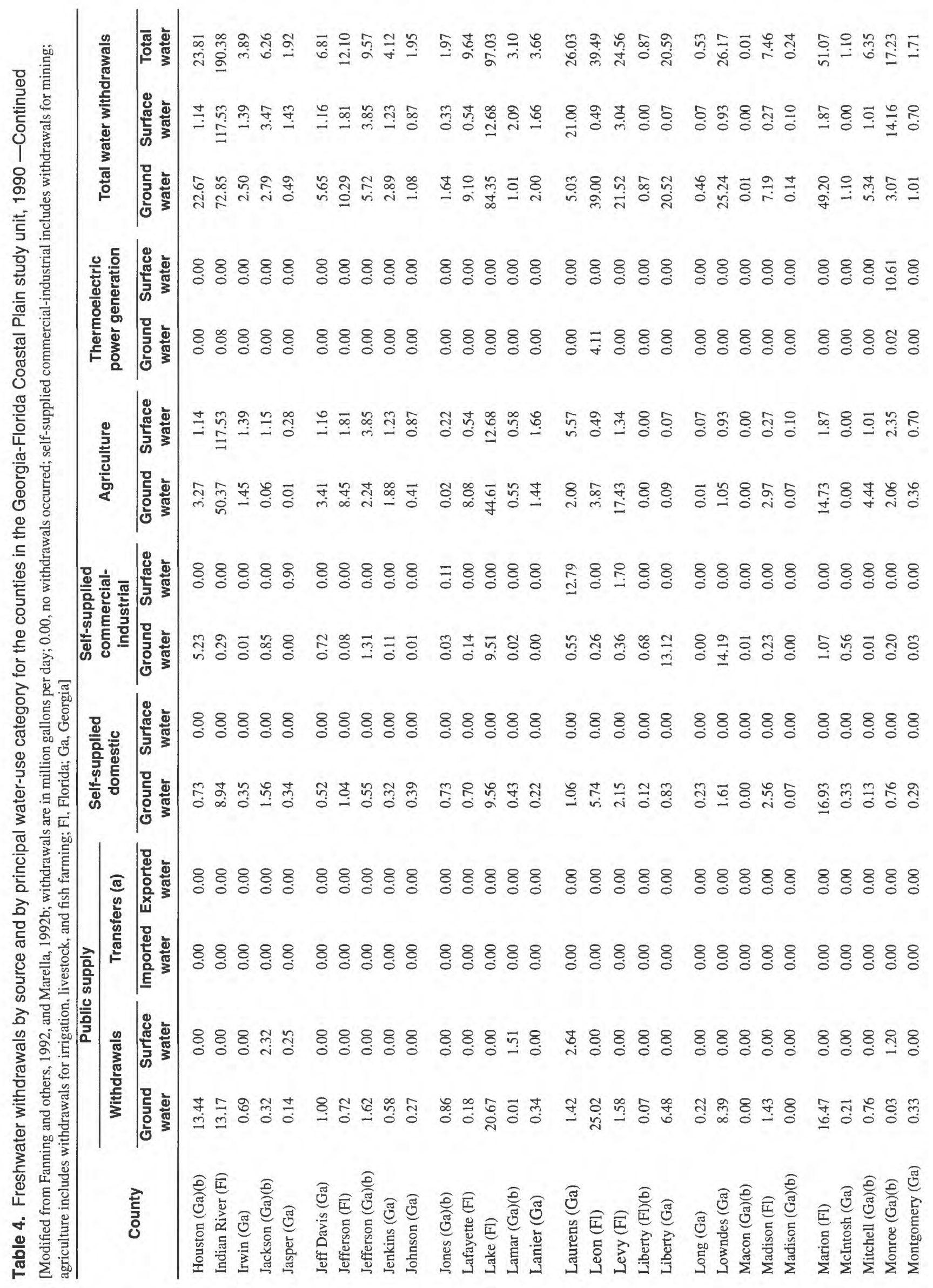




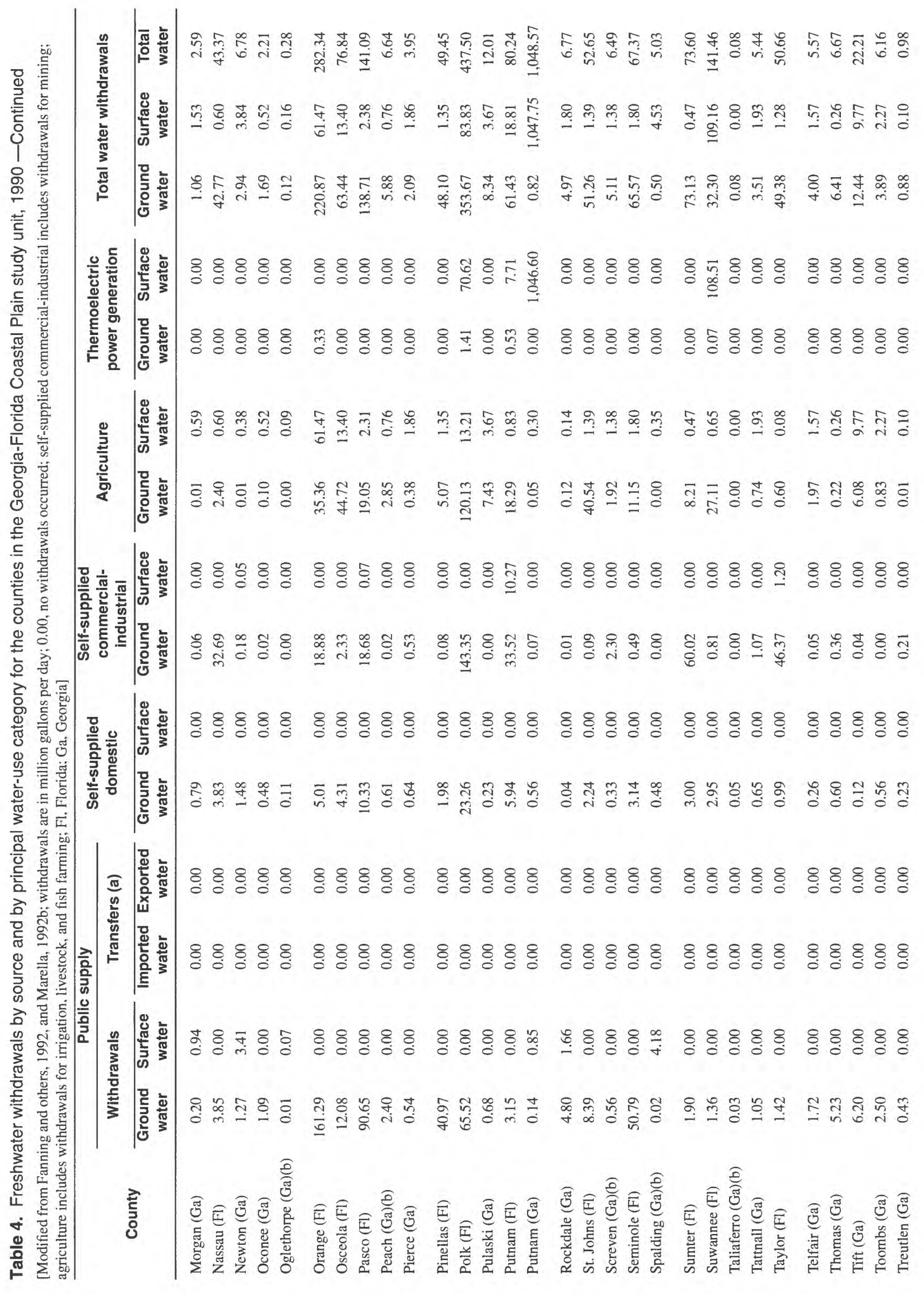




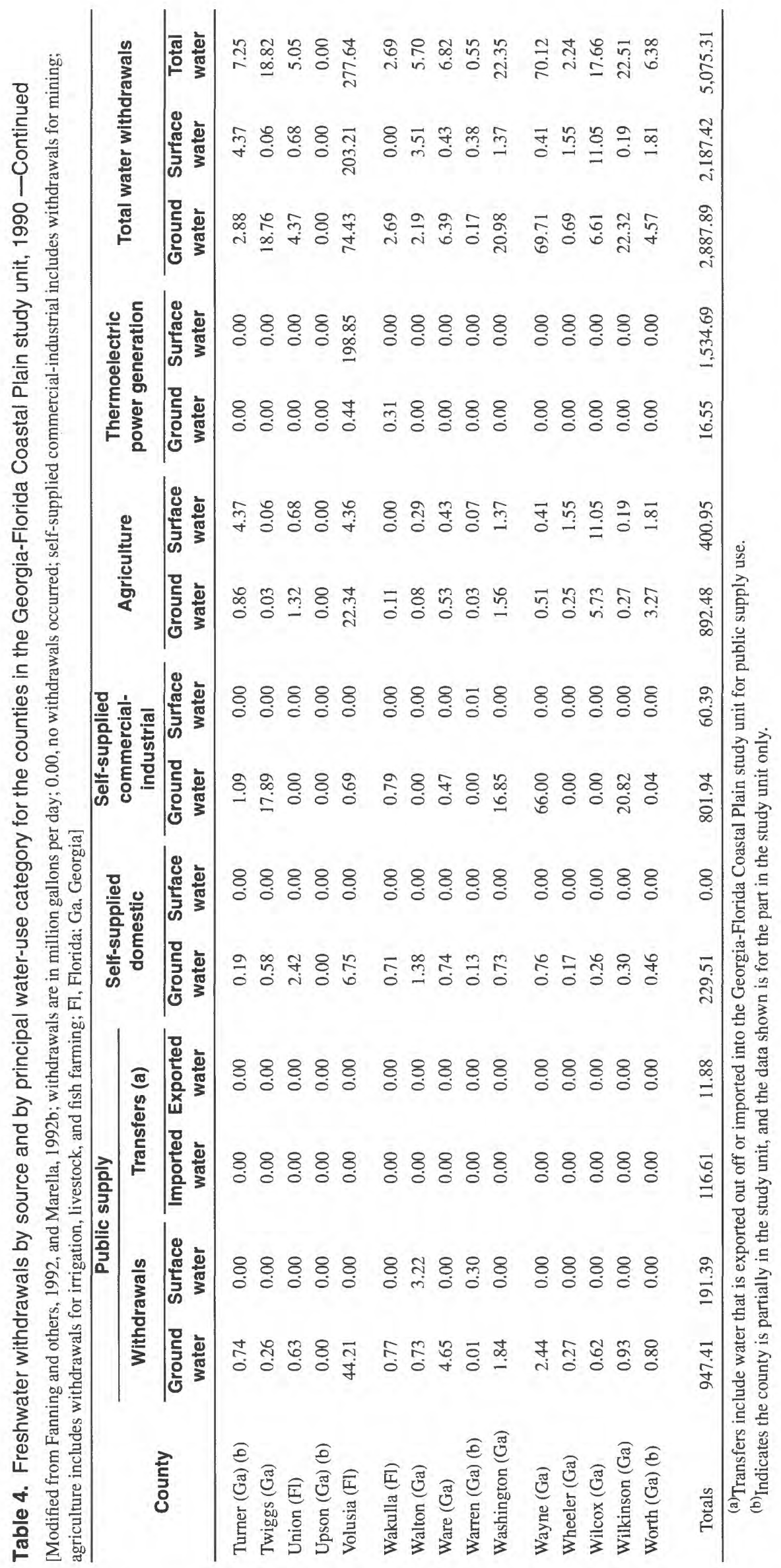




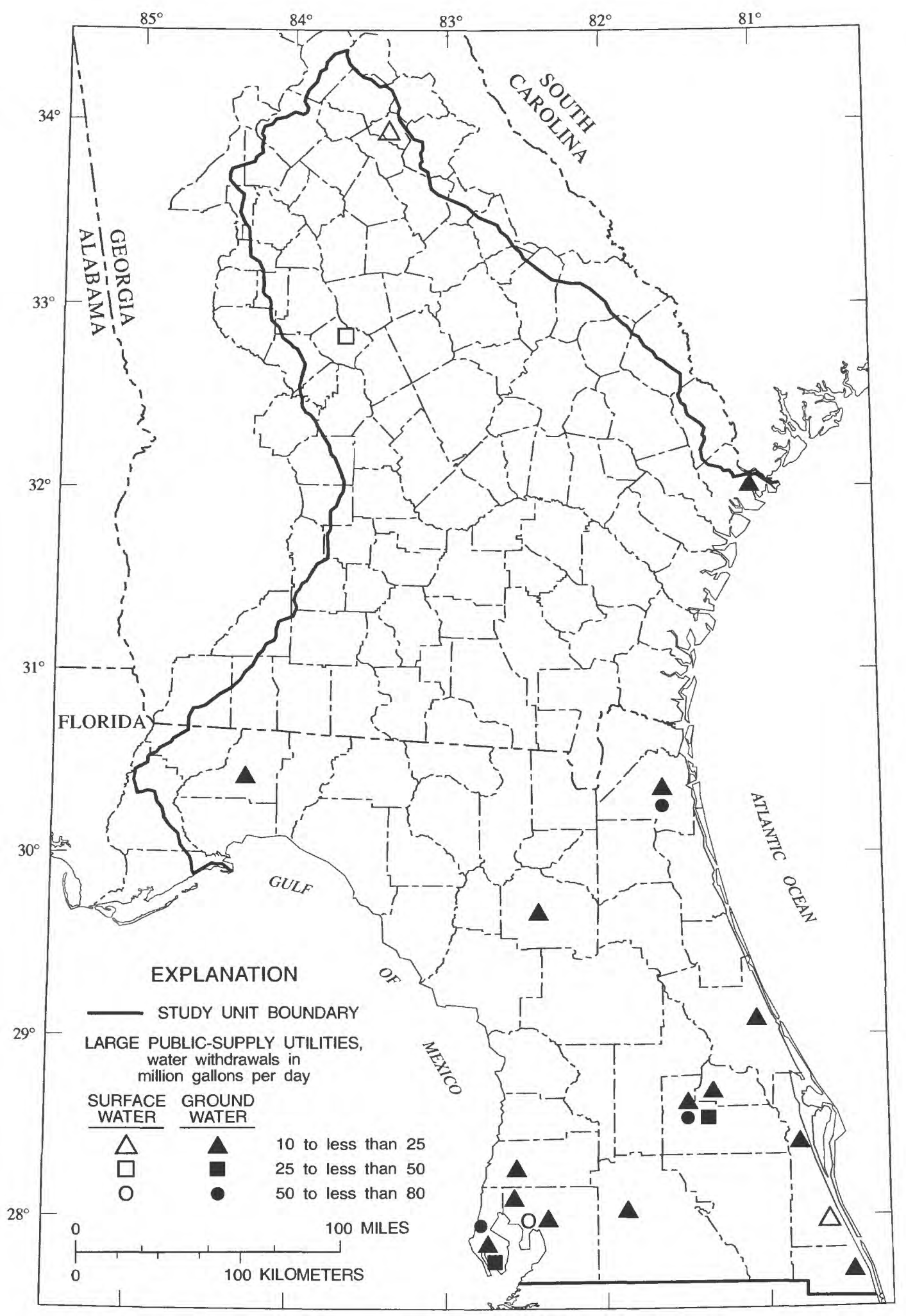

Figure 8. General locations of the largest public-supply utilities in the Georgia-Florida Coastal Plain study unit, 1990. 
Counties on the east coast of Florida and were treated through a desalination process or diluted with fresher water. The use of nonpotable water for public supply has increased in this part of Florida from nearly 1 $\mathrm{Mgal} / \mathrm{d}$ in 1985, to $5 \mathrm{Mgal} / \mathrm{d}$ in 1990 (in 1985, nonpotable water was originally referred to as saline ground water) (Marella, 1992b). Within the study unit, 10 public-supply systems treated or diluted nonpotable water in order to meet the drinking water standards.

Surface water is the primary source for public supply water in the extreme northwestern part of the study unit. Throughout the remaining areas of the study unit, surface water is only used by a handful of public suppliers. In 1990, surface water withdrawn for public supply in the study unit totaled $191 \mathrm{Mgal} / \mathrm{d}$ (table 1 and fig. 6). The Hillsborough River supplied 40 percent $(76 \mathrm{Mgal} / \mathrm{d})$ and the Ocmulgee and Oconee Rivers each supplied about 12 percent $(47 \mathrm{Mgal} / \mathrm{d}$ combined) of the surface-water withdrawn (fig. 1). An additional $105 \mathrm{Mgal} / \mathrm{d}$ of surface water was imported into the study unit for public supply use (Marella and others, 1993). The water was imported from the Chattahoochee River (including Lake Sidney Lanier) in the metropolitan Atlanta area (primarily in DeKalb, Fulton, and Gwinnett Counties) (fig. 3) Some of this water was treated and discharged back into the Chattahoochee River after being used, but some water was discharged into the Altamaha-St. Marys River basin. The amount of water transferred between these basins varies from year to year.

\section{Self-Supplied Domestic}

Self-supplied domestic withdrawals in the Georgia-Florida Coastal Plain study unit in 1990 totaled nearly $230 \mathrm{Mgal} / \mathrm{d}$ (table 1 ). Withdrawals for self-supplied domestic use within the study unit decreased 2 percent from 1985 to 1990 but increased 2 percent from 1980 to 1990 (table 3 and fig. 7). Selfsupplied water withdrawals remained about the same over this period primarily from an increase in rural population throughout the study unit and a decrease in self-supplied users around urban areas. The decrease occurred as many public-water supplies expanded their water systems into unincorporated areas. Most of this expansion is occurring in or around some large urban areas (Atlanta, Jacksonville, Orlando, and Tampa). In 1990, nearly 1.8 million people obtained drinking water from self-supplied systems or small public supply systems that were not inventoried. Because a large part of the study unit is rural, a signifi- cant percentage of the population within the study unit will always rely on self-supplied water systems. Florida accounted for nearly 78 percent and Georgia 22 percent of the water withdrawn for self-supplied domestic use during 1990.

Water withdrawn for self-supplied domestic use in Georgia and Florida is derived almost exclusively from ground water, primarily because this source can provide the quantity and quality of water needed for drinking purposes. Also, in most areas in the study unit, surface water does not meet drinking water standards without treatment. The Floridan aquifer system supplied 65 percent $(151 \mathrm{Mgal} / \mathrm{d})$ of the ground-water withdrawn for self-supplied domestic use in the study unit, followed by 21 percent ( $47 \mathrm{Mgal} / \mathrm{d}$ ) from the surficial aquifers and 14 percent $(32 \mathrm{Mgal} / \mathrm{d})$ from the other aquifers (table 2). In many areas of the study unit, the surficial aquifers yield sufficient water for domestic purposes, precluding the need to tap the deeper Floridan aquifer system. The surficial and other aquifers are primarily used where the Floridan aquifer system is extremely deep below land surface (northeastern part of Florida and southeastern part of Georgia), or in other areas where the water from the Floridan aquifer system is nonpotable. In areas where the Floridan aquifer system is not present in northcentral Georgia (fig. 2), the Claiborne, Cretaceous, and Crystalline Rock aquifers are used for self-supplied needs.

Polk and Marion Counties in Florida accounted for the largest amounts of water withdrawn for selfsupplied domestic use in 1990, using $23 \mathrm{Mgal} / \mathrm{d}$ and $17 \mathrm{Mgal} / \mathrm{d}$ respectively (table 4). Most of the selfsupplied water withdrawn in Polk (75 percent) and Marion (94 percent) is estimated to be from the Floridan aquifer system. In other counties with substantial withdrawals such as Brevard, Duval, Indian River, and Nassau Counties, more than 90 percent of the self-supplied water withdrawn is from the surficial aquifers.

\section{Self-Supplied Commercial-Industrial}

Water withdrawn for self-supplied commercialindustrial use (including mining needs) in the GeorgiaFlorida Coastal Plain study unit in 1990 totaled about $862 \mathrm{Mgal} / \mathrm{d}$ (table 1), of which 93 percent was ground water and 7 percent was surface water. Withdrawals for self-supplied commercial-industrial uses within the study unit decreased 2 percent from 1985 to 1990 and 6 percent from 1980 to 1990 (table 3 and fig. 7). 
24 percent by flood irrigation systems. The general location of the more intensely irrigated areas within the Georgia-Florida Coastal Plain study unit are shown in figure 10. Citrus (30 percent) and vegetable (including truck farming) irrigation (20 percent) accounted for the largest amount of water withdrawn for irrigation in the study unit for 1990 . About 0.251 million acres of citrus, grown mostly in 15 counties, was irrigated in the study unit during 1990. Polk, Indian River, and Hillsborough Counties accounted for 75 percent of the citrus acreage. Citrus in Hillsborough and Polk Counties is predominantly irrigated by ground water through sprinkler and low pressure systems. The water is pumped on an "as need" bases, and generally percolates quickly through the sandy soils. Citrus in Indian River County is predominantly irrigated by surface water through flood irrigation (primarily crown flood irrigation) with some ground water used for low pressure and sprinkler systems. Surface water is primarily obtained from a series of canals, and is gravity fed into the citrus groves, where the water floods the soil above the root zone of the tree. Once the water has saturated the soils, the excess water is then pumped out of the grove and back into the canal. Access to the canal water occurs on a predetermined time schedule (usually in days). In dry periods, many of the irrigators use ground water from free-flowing wells to augment the water levels in these canals or groves.

Vegetable irrigation occurs in several areas within the study unit (fig. 10) and generally runs from February through November. In Hillsborough County, ground water is withdrawn to irrigate tomatoes and strawberries through sprinklers, low pressure, or flood systems. In Flagler, Putnam, and St. Johns Counties, ground water is withdrawn to irrigate potatoes and cabbage through flood or sprinklers systems. In Lake and Orange Counties, surface water is used to irrigate a variety of vegetables (cabbage, carrots, celery, radishes, sweet corn, and others) through flood systems. This surface water is also supplemented by ground water from free-flowing wells during the irrigation seasons. Throughout northern Florida and southern Georgia, ground water is used by center pivots or traveling guns to irrigate crops such as corn, cotton, watermelons, and a variety of spring and summer vegetable crops. Brooks, Colquitt, Tift, and Worth Counties in Georgia and Alachua, Madison, Jefferson, and Suwannee Counties in Florida are some of the more intense areas involved in agricultural production in southern Georgia and northern Florida. Many dairy and poultry operations, along with several horse farming or breeding operations are located within the study unit (predominantly in the northern Florida and northern and southern Georgia areas). Most of the water withdrawn at these operations is used for animal and equipment washdown, animal drinking and cooling purposes, and augmenting farm ponds.

Ground water is the primary source of water for agricultural needs throughout the study unit because it is readily available and is highly dependable in both quantity and quality. In 1990, ground water withdrawn for agricultural purposes in the study unit totaled about $892 \mathrm{Mgal} / \mathrm{d}$ (table 1 and fig 7). The Floridan aquifer system supplied 93 percent ( $827 \mathrm{Mgal} / \mathrm{d}$ ) of the ground-water withdrawn for agricultural purposes in the study unit for 1990 (table 2). The remaining water was withdrawn from surficial aquifers or other aquifers. Polk County withdrew the largest amount of ground water $(120 \mathrm{Mgal} / \mathrm{d})$ for agricultural purposes in 1990 (120 Mgal/d), followed by Brevard County (101 Mgal/d) and Hillsborough County (89 Mgal/d) (table 4).

The surface-water withdrawn in the study unit for agricultural irrigation was predominantly obtained from unnamed canals or ditches, local lakes or ponds, or small creeks or tributaries within the study unit. In 1990, surface water withdrawn for agricultural purposes in the study unit totaled about $401 \mathrm{Mgal} / \mathrm{d}$ (table 1 and fig. 7). Indian River County (118 Mgal/d) and Orange County (61 Mgal/d) withdrew the largest amount of surface water for agricultural purposes in 1990 (table 4). Most of the surface-water withdrawn in Indian River County is from the many canals associated with the St. Johns River marshlands while in Orange County the water is primarily from Lake Apopka (fig. 1). Excess or unused water from these flood irrigation operations in Indian River and Orange Counties is usually pumped back into the source on a regular bases.

More than $111 \mathrm{Mgal} / \mathrm{d}$ of reclaimed wastewater was used for irrigation purposes in the study unit during 1990. The city of St. Petersburg (Pinellas County) used nearly $28 \mathrm{Mgal} / \mathrm{d}$ of reclaimed wastewater in 1990 to irrigate commercial and residential lawns as well as golf courses within the county (Marella, 1994). Large reuse systems were also in operation in the Atlanta area (Clayton County), the Orlando area (Orange and Seminole Counties), and in Tallahassee 


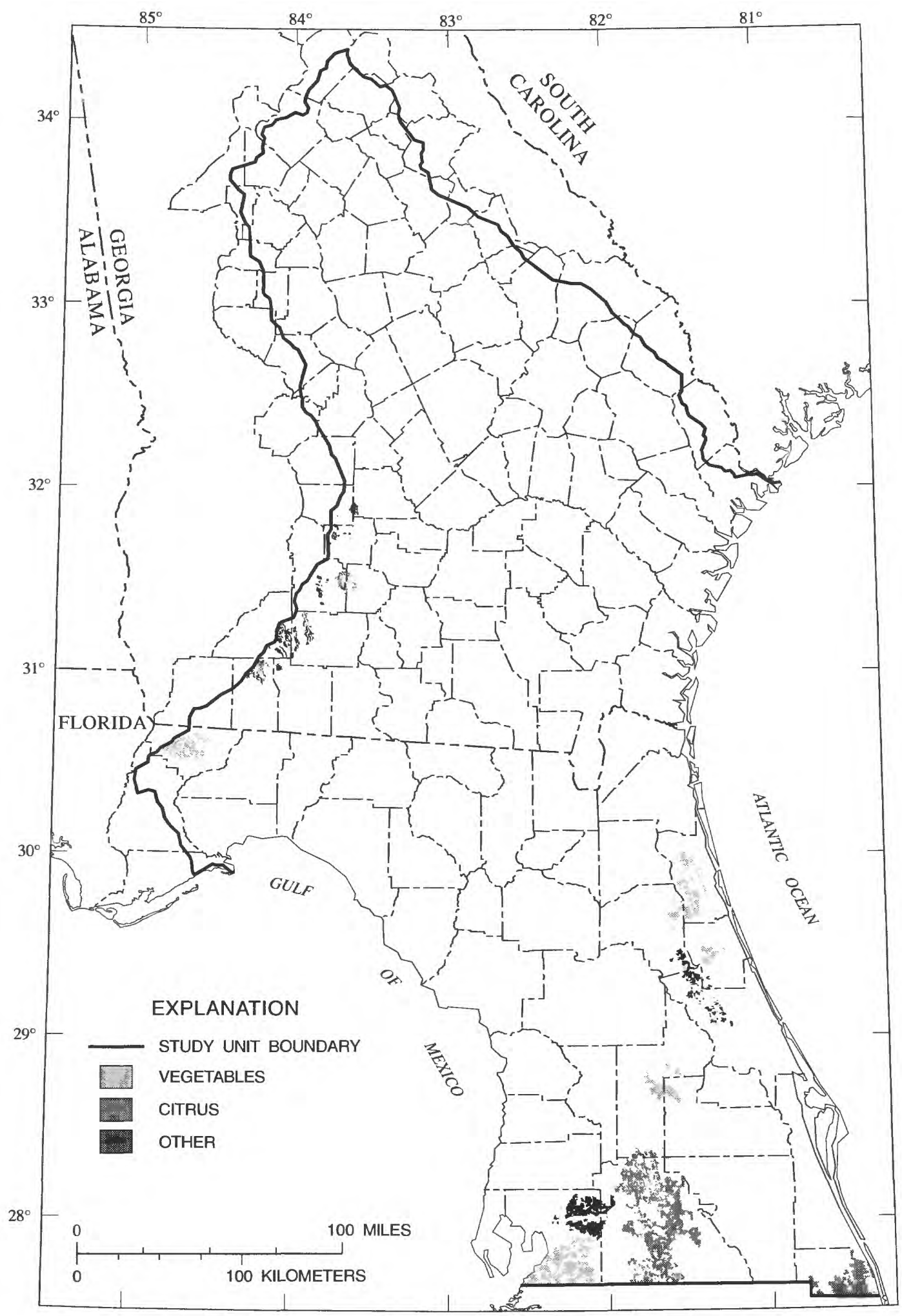

Figure 10. General locations of the more intensively irrigated agricultural areas in the Georgia-Florida Coastal Plain study unit, 1990. 
The decrease is a result of many factors including a change by commercial and industrial users from selfsupplied to obtaining water from public-supply systems, increases in water conservation practices and restrictions on withdrawals, and a change in the overall economic base throughout the area from manufacturing to services and tourism. Furthermore, because of the increasing cost of treating and discharging industrial wastewater coupled with the threat of saltwater intrusion in the coastal areas, many industries obtain water from a public supplier and/or reuse (recycle) as much water as possible. Florida accounted for nearly 62 percent and Georgia 38 percent of the water withdrawn for self-supplied commercial-industrial use in the study unit during 1990.

Nearly 63 percent of the water withdrawn for self-supplied commercial-industrial purposes was used for industrial manufacturing or processing, 31 percent for mining uses, and 6 percent for commercial needs. Large pulp and paper mills and related chemical processing facilities are primarily located in northern Florida (Duval, Nassau, Putnam, and Taylor Counties) and eastern Georgia (Camden, Chatham, Glynn, Liberty, Lowndes, and Wayne Counties). Limerock and phosphate mining operations and related chemical processing facilities are primarily located in southwestern Florida (Hernando, Hillsborough, Polk, and Sumter Counties) while other mining (sand, stone, or clay production) occurs in Johnson, Twiggs, and Washington Counties (Georgia) and Clay, Hamilton, and Putnam Counties (Florida). The general locations of the 20 self-supplied commercialindustrial facilities within the study unit that withdrew more than $10 \mathrm{Mgal} / \mathrm{d}$ during 1990 are shown in figure 9.

Ground water is the primary source for commercial-industrial self-supplied water throughout the study unit because it is readily available, is of good quality in most areas, and usually requires very little treatment before use. In 1990, ground water withdrawn for commercial-industrial self-supplied use in the study unit totaled about $802 \mathrm{Mgal} / \mathrm{d}$ (table 1 and fig 6). The Floridan aquifer system supplied 93 percent $(742 \mathrm{Mgal} / \mathrm{d})$ of the ground-water withdrawn for self-supplied commercial-industrial use in the study unit for 1990 (table 2). The remaining water was withdrawn from surficial aquifers or other aquifers. Polk County withdrew the largest amount of ground water (143 Mgal/d) for commercial-industrial purposes in 1990 (table 4). In eastern Georgia, Bryan,
Camden, Chatham, Liberty, McIntosh, and Wayne Counties and in northeast Florida, Duval, Nassau, and Putnam Counties, more than $300 \mathrm{Mgal} / \mathrm{d}$ of ground water was withdrawn for pulp and paper production during 1990. All of this water was withdrawn from the Floridan aquifer system.

Surface water is the primary source for commercial-industrial self-supplied purposes in the extreme northwestern part of the study unit. Throughout the remaining areas of the study unit, surface water is only used by a handful of industries. In 1990, surface water withdrawn for commercial-industrial self-supplies in the study unit totaled $60 \mathrm{Mgal} / \mathrm{d}$ (table 1 and fig. 6). Bibb and Laurens Counties in Georgia accounted for more than 40 percent of the surface water withdrawn for commercial-industrial purposes in 1990 (table 4). Most surface water used for commercial-industrial purposes was withdrawn from rivers, streams, canals, or lakes within the study unit. Surface water withdrawn in the study unit was primarily used for cooling or washing purposes.

\section{Agriculture}

Water withdrawn for agricultural purposes (including water used for irrigation, livestock, fish farming, and frost or freeze protection) in the GeorgiaFlorida Coastal Plain study unit in 1990 totaled 1,293 Mgal/d (table 1), of which 69 percent was ground water and the 31 percent was surface water. Withdrawals for agricultural purposes within the study unit increased 3 percent from 1985 to 1990 and 7 percent from 1980 to 1990 (table 3 and fig. 7). Part of the increase was a result of an increase in water withdrawals for citrus, primarily due to an increase in acreage from replanting freeze-damaged groves in the extreme southern portions of the district (Hillsborough, Indian River, and Polk Counties). However, citrus acreage in the study unit decreased 6 percent $(0.017$ million acres) between 1985 and 1990, as losses occurred in Lake, Orange, Pasco, Seminole and Volusia Counties. Additionally, increases in vegetable (truck crops) and ornamentals (nursery) acreage occurred in several areas between 1980 and 1990, resulting in increased water usage. Florida accounted for 81 percent and Georgia 19 percent of the water withdrawn for agricultural purposes in the study unit during 1990.

An estimated 1.254 million acres were irrigated within the study unit during 1990, with 76 percent irrigated by sprinkler or low pressure systems and 


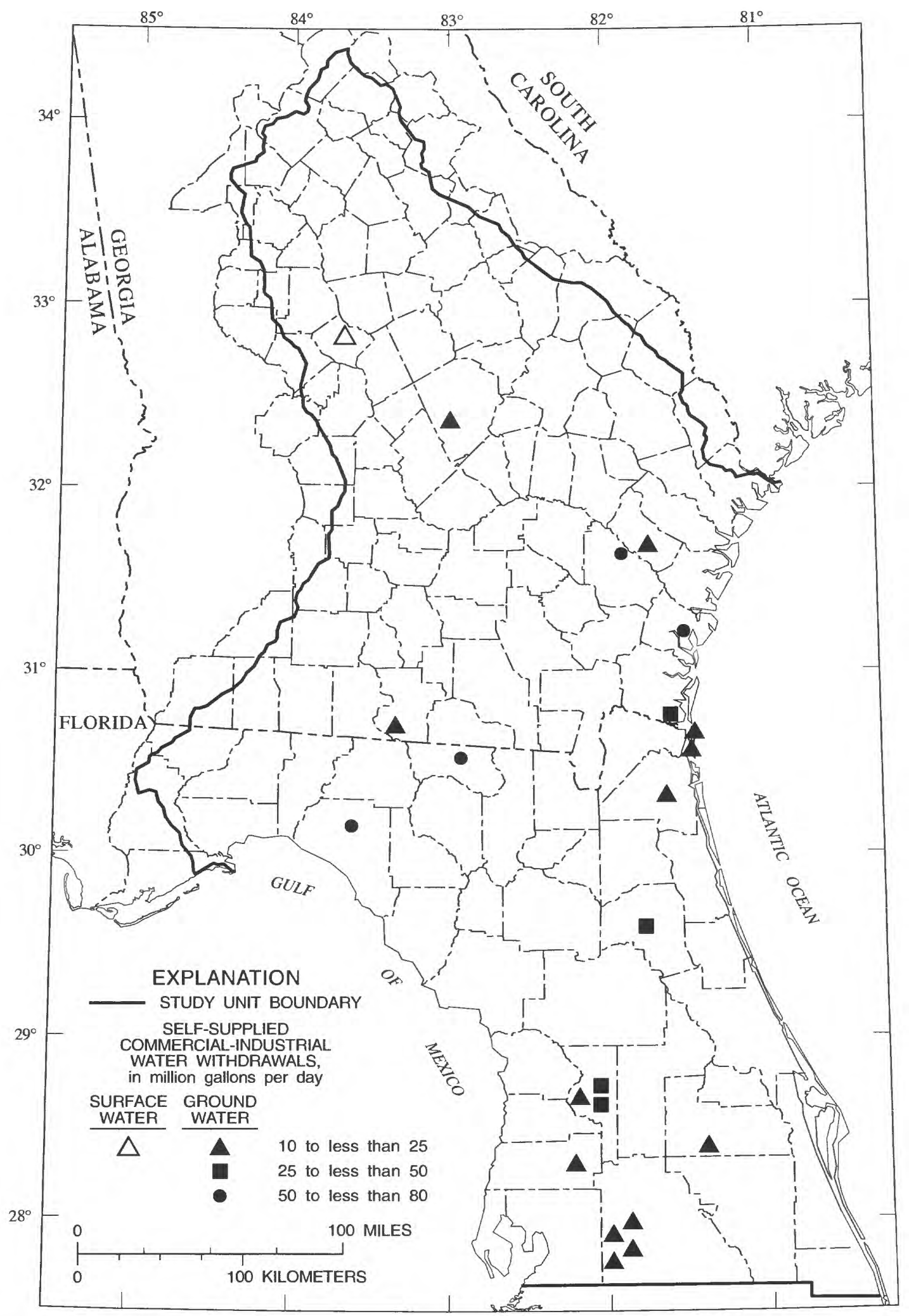

Figure 9. General locations of the largest self-supplied commercial-industrial facilities in the GeorgiaFlorida Coastal Plain study unit, 1990. 
(Leon County). The use of reclaimed wastewater in the study unit has increased substantially over the past ten years due to the stress imposed on the resources caused by an increase in water demand along with the need to better dispose of treated wastewater.

\section{Thermoelectric Power Generation}

Freshwater withdrawn for thermoelectric power generation in the Georgia-Florida Coastal Plain study unit in 1990 totaled nearly $1,552 \mathrm{Mgal} / \mathrm{d}$ (table 1), of which 99 percent was surface water and only 1 percent was ground water. Freshwater withdrawn (fresh) for thermoelectric power generation within the study unit decreased 2 percent from 1985 to 1990 and 26 percent from 1980 to 1990 (table 3 and fig. 7). The decreases in water withdrawn for thermoelectric power generation is a result of the recirculation of cooling water and the building of newer, more efficient facilities. Since 1970, many powerplants in Florida and Georgia recycling their once-through cooling water through ponds and only withdrawal water to augment or supplement these ponds. Also, many of the powerplants built between 1970 and 1990 were built along the coast and use saline water for cooling purposes or were built with cooling towers for oncethrough cooling purposes (Marella, 1995). Furthermore, most of the older inefficient powerplants have been phased out or are used for stand-by purposes only, while the power generation capacities of the newer, more efficient facilities have increased substantially. Currently, most of the water withdrawn for thermoelectric power generation purposes within the study unit is from saline surface-water sources $(6,919 \mathrm{Mgal} / \mathrm{d})$ and is exclusively used for oncethrough cooling. Georgia accounted for 75 percent and Florida 25 percent of the freshwater withdrawn for thermoelectric power generation in the study unit during 1990. A total of 34 thermoelectric power facilities (fig. 11) and 7 hydroelectric powerplants were located and operated within the study unit in 1990. Power generated by these 41 facilities during 1990 totaled 119,860 gigawatthours.

Most of the water used for thermoelectric power generation within the study unit is surface water used for once-through cooling and is returned to the source with little or no consumption. Surface water is the primary source of water for cooling purposes because a high volume of water is needed and the quality of the water is not critical. In 1990, surface water withdrawn for thermoelectric purposes in the study unit totaled
1,535 Mgal/d (table 4). Nearly 68 percent of the surface water was withdrawn from the Oconee River in Putnam County Georgia, while the remaining surface water was withdrawn from the Ocmulgee, St. Johns, and Suwannee Rivers. Some of the saline sources include the Indian River, St. Johns River, St. Marks River, and the Turtle River, as well as other coastal water bodies. Most of these rivers are fresh water rivers, however in the areas were these rivers meet the coast, they are tidal influenced, and are most often a mix of fresh and saline waters. Because the percentage of fresh and saline water changes often, but is predominately saline, the withdrawals in these areas are considered saline. Several powerplants in Hillsborough, Orange, Osceola and Polk Counties used reclaimed wastewater directly or water from a wastewater-supplemented lake or reservoir for once-through cooling purposes.

Ground water withdrawn for thermoelectric power generation in the study unit totaled almost $17 \mathrm{Mgal} / \mathrm{d}$ in 1990 . The majority of this water is used for boiler makeup or domestic purposes throughout the plant. Ground water is the primary source of water for boiler makeup and domestic purposes at facilities located in remote rural areas, while water from public supply is the primary source of water for these purposes at facilities in urban areas. The Floridan aquifer system supplied nearly all of the ground water for the powerplants in the study unit (table 2). Duval and Leon Counties accounted for the largest amount of ground-water withdrawn (5 Mgal/d and $4 \mathrm{Mgal} / \mathrm{d}$ respectively) (table 4).

\section{Water Withdrawals by River Basin}

Located within the Georgia-Florida Coastal Plain study unit are all or part of seven major river basins (fig. 12). These River basins include; the Ogeechee, Altamaha-St. Marys, St. Johns, Southern Florida, Peace-Tampa Bay, Suwannee, and the Ochlockonee (Seaber and others, 1987). Only the Altamaha-St. Marys, Suwannee, Ochlockonee and the Ogeechee basins are entirely within the study unit; the others are only partially in the study unit. The seven basins are also identified as subregions by the USGS. Within these major river basins are smaller divisions (cataloging units) which provide further detail on the each basin. The cataloging unit provides the greatest level of detail on each basin, as these units divide the river into smaller drainage sections or tributaries. 


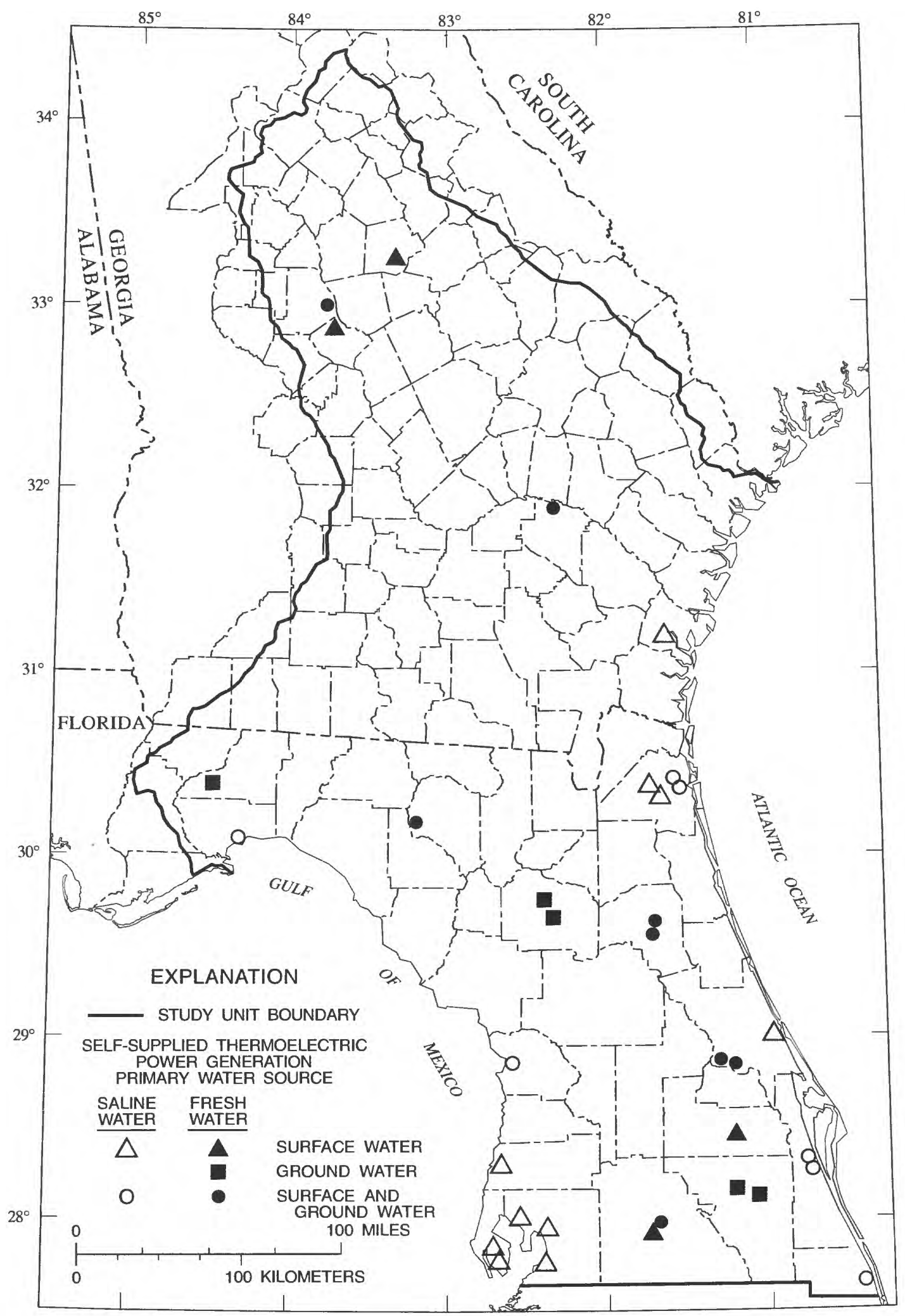

Figure 11. General locations of the self-supplied thermoelectric power generation facilities in the Georgia-Florida Coastal Plain study unit, 1990. 


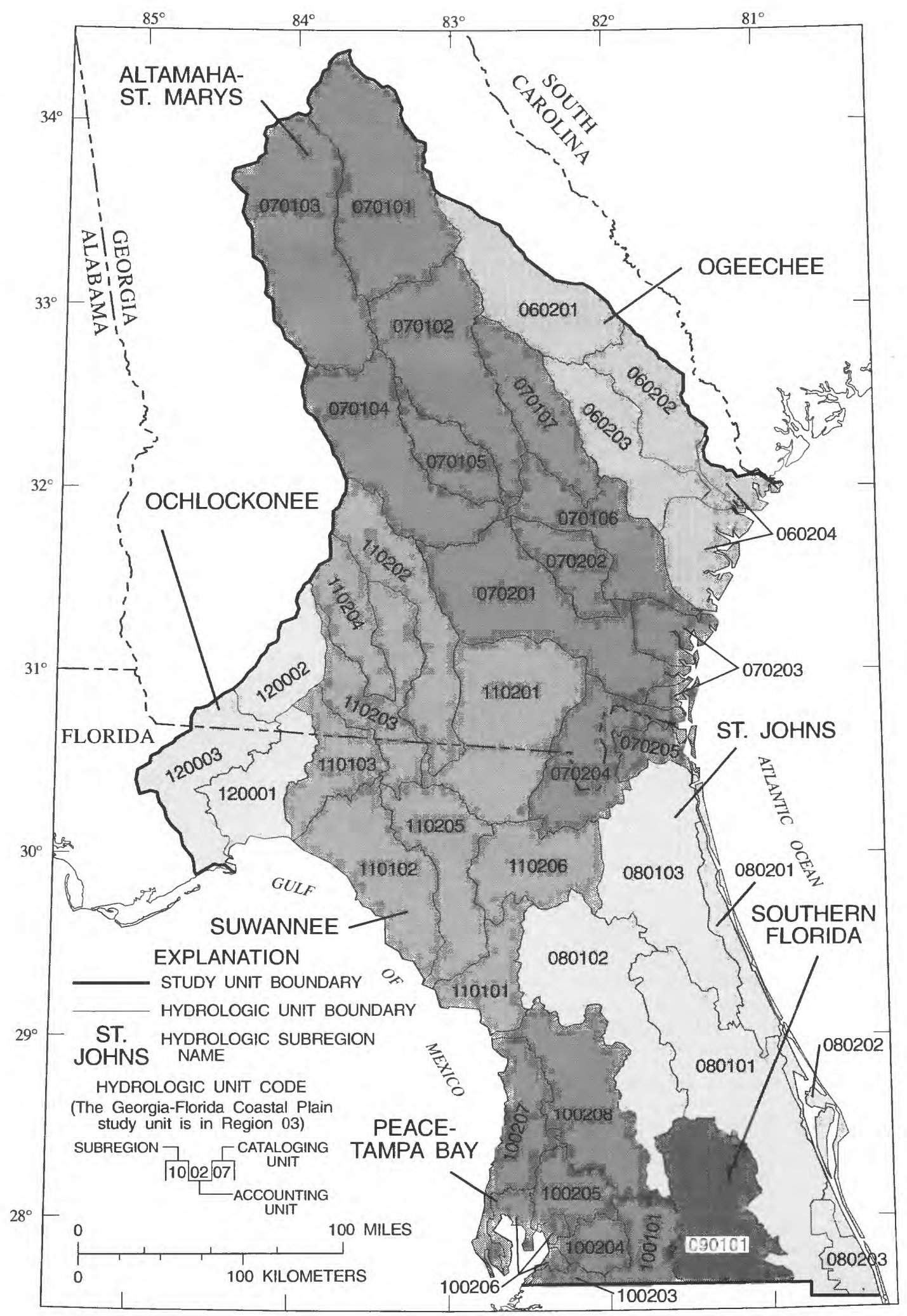

Figure 12. Locations of major river basins in the Georgia-Florida Coastal Plain study unit. 
For example, within the Ochlockonee River basin are the following cataloging units; Apalachee Bay-St. Marks, Upper Ochlockonee River, and the Lower Ochlockonee River. Located within the seven major river basins (subregions) are all or part of 42 cataloging units (fig 12). The names and cataloging unit numbers of each major river basin are as follows:

\begin{tabular}{|c|c|}
\hline \multicolumn{2}{|c|}{ Ogeechee (4 units) } \\
\hline Upper Ogeechee River & 03060201 \\
\hline Lower Ogeechee River & 03060202 \\
\hline Canoochee River & 03060203 \\
\hline Ogeechee Coastal & 03060204 \\
\hline \multicolumn{2}{|c|}{ Altamaha-St. Marys (12 units) } \\
\hline Upper Oconee River & 03070101 \\
\hline Lower Oconee River & 03070102 \\
\hline Upper Ocmulgee River & 03070103 \\
\hline Lower Ocmulgee River & 03070104 \\
\hline Little Ocmulgee River & 03070105 \\
\hline Altamaha River & 03070106 \\
\hline Ohoopee River & 03070107 \\
\hline Satilla River & 03070201 \\
\hline Little Satilla River & 03070202 \\
\hline Cumberland - St. Simons Coastal & 03070203 \\
\hline St. Marys River & 03070204 \\
\hline Nassau River & 03070205 \\
\hline \multicolumn{2}{|c|}{ St. Johns (6 units) } \\
\hline Upper St. Johns River & 03080101 \\
\hline Oklawaha River & 03080102 \\
\hline Lower St. Johns River & 03080103 \\
\hline Daytona - St. Augustine Coastal & 03080201 \\
\hline Cape Canaveral Coastal & 03080202 \\
\hline Vero Beach Coastal & 03080203 \\
\hline \multicolumn{2}{|c|}{ Southern Florida (1 unit) } \\
\hline Kissimmee River & 03090101 \\
\hline \multicolumn{2}{|c|}{ Peace-Tampa Bay (7 units) } \\
\hline Peace River & 03100101 \\
\hline Little Manatee River & 03100203 \\
\hline Alafia River & 03100204 \\
\hline Hillsborough River & 03100205 \\
\hline Tampa Bay & 03100206 \\
\hline Crystal - Pithlachascotee & 03100207 \\
\hline Withlacoochee River & 03100208 \\
\hline \multicolumn{2}{|c|}{ Suwannee (9 units) } \\
\hline Waccasassa River & 03110101 \\
\hline Econfina - Steinhatchee & 03110102 \\
\hline Aucilla River & 03110103 \\
\hline Upper Suwannee River & 03110201 \\
\hline Alapaha River & 03110202 \\
\hline Withlacoochee River & 03110203 \\
\hline Little River & 03110204 \\
\hline
\end{tabular}

\begin{tabular}{lc}
\multicolumn{2}{c}{ Suwannee--Continued } \\
Lower Suwannee River & 03110205 \\
Santa Fe River & 03110206 \\
& Ochlockonee (3 units) \\
Apalachee River & 03120001 \\
Upper Ochlockonee River & 03120002 \\
Lower Ochlockonee River & 03120003
\end{tabular}

Of the 42 cataloging units, 36 are entirely within the study unit, and 6 are partially within the study unit (Upper St. Johns River, Vero Beach Coastal, Kissimmee River, Peace River, Little Manatee River, and Tampa Bay). These cataloging units are shown on the USGS Hydrologic Unit Map, 1:500,000 scale (1974, 1975 ) for the State's of Florida and Georgia (USGS, 1975) and detailed in Seaber and others (1987).

The Suwannee River basin covers the largest land area of the major river basins in the study unit (26 percent), followed by the Altamaha-St. Marys River basin (23 percent), and the St. Johns River basin (22 percent). The Altamaha-St. Marys and the Suwannee river basins are entirely within the study unit, whereas a small part of the St. Johns River basin (2 percent) is not within the study unit. The Altamaha-St. Marys and the Suwannee river basin drain a part of both Georgia and Florida. The St. Johns River basin was the most populated basin in the study unit in 1990 (3.087 million), followed by the Peace-Tampa Bay River basin (2.644 million), and the AltamahaSt. Marys River basin (2.130 million) (table 5). Within the St. Johns River basin is the part of Orlando (Orange County) MSA as well as metropolitan areas that run along the east coast of Florida from Jacksonville (Duval County) to Melbourne (Brevard County) (fig 1. and fig. 12). Within the Peace-Tampa Bay River basin is the Tampa-St. Petersburg-Clearwater MSA, and within the Altamaha-St. Marys River basin is a large part of the Atlanta MSA.

The most populated cataloging unit in the study unit in 1990 was the Upper Ocmulgee River (1.188 million), followed by the Upper St. Johns River (0.961 million), and the Lower St. Johns River (0.873 million) (app. 2, table A). The Upper Ocmulgee River cataloging unit includes a large part of the metropolitan Atlanta area, the Upper St. Johns River includes a large part of the Orlando area, and the Lower St. Johns River includes most of the Jacksonville area. The Upper Ocmulgee River cataloging unit had the most people served by surface water for public supply (0.980 million) and the Upper St. Johns River had the most people served by ground water for public supply (0.876 million) in 1990 (app. 2, table A). 
Table 5. Population and freshwater withdrawals by major river basin (subregion) in the Georgia-Florida Coastal Plain study unit, 1990

\begin{tabular}{|c|c|c|c|c|c|}
\hline \multicolumn{2}{|c|}{$\begin{array}{c}\text { Hydrological unit } \\
\text { Major river basin - subregions }{ }^{1}\end{array}$} & \multirow[b]{2}{*}{ Population } & \multicolumn{3}{|c|}{ Withdrawals, in million gallons per day } \\
\hline Subregion name & unit number & & Ground water & Surface water & Total water \\
\hline Ogeechee & 0306 & 352,130 & 78.74 & 22.08 & 100.82 \\
\hline Altamaha-St. Marys & 0307 & $2,130,390$ & 445.84 & $1,338.25$ & $1,784.09$ \\
\hline St. Johns ${ }^{(2)}$ & 0308 & $3,087,259$ & 970.50 & 457.88 & $1,428.38$ \\
\hline Southern Florida ${ }^{(2)}$ & 0309 & 255,660 & 163.16 & 10.23 & 173.39 \\
\hline Peace-Tampa Bay ${ }^{(2)}$ & 0310 & $2,643,527$ & 830.28 & 177.05 & $1,007.33$ \\
\hline Suwannee & 0311 & 486,370 & 318.97 & 161.84 & 480.81 \\
\hline Ochlockonee & 0312 & 312,050 & 80.40 & 20.09 & 100.49 \\
\hline Totals & & $9,267,386$ & $2,887.89$ & $2,187.42$ & $5,075.31$ \\
\hline
\end{tabular}

(1) Refer to figure 12 for the location of subregion (Seaber and others, 1987).

${ }^{(2)}$ Indicates the subregion is partially in the study unit, and the data shown is for the part withinthe study unit only.

The Altamaha-St. Marys River basin accounted for the largest amount of water withdrawn in the Georgia-Florida Coastal Plain study unit during 1990 (1,784 Mgal/d), followed by the St. Johns River basin $(1,428 \mathrm{Mgal} / \mathrm{d})$ and the Peace-Tampa Bay River basin (1,007 Mgal/d) (table 5). The Altamaha-St. Marys River basin accounted for the largest amount of surface water withdrawn in 1990 (61 percent), followed by the St. Johns River basin ( 21 percent) (fig. 13). The St. Johns River basin accounted for the largest amount of ground water withdrawn in 1990 (34 percent), followed by the Peace-Tampa Bay basin (29 percent) (fig. 13).
The most surface water withdrawn in the study unit during 1990 (1,077 Mgal/d) occurred in the Upper Oconee River cataloging unit (03070101). The majority (97 percent) of the surface water in this cataloging unit was withdrawn for thermoelectric power generation purposes (app. 2, table B). The most ground water withdrawn in the study unit during 1990 (331 Mgal/d) occurred in the Upper St. Johns River cataloging unit (03080101). The majority (57 percent) of the ground water in this cataloging unit was withdrawn for public-supply purposes. The following cataloging units accounted for the largest amount of

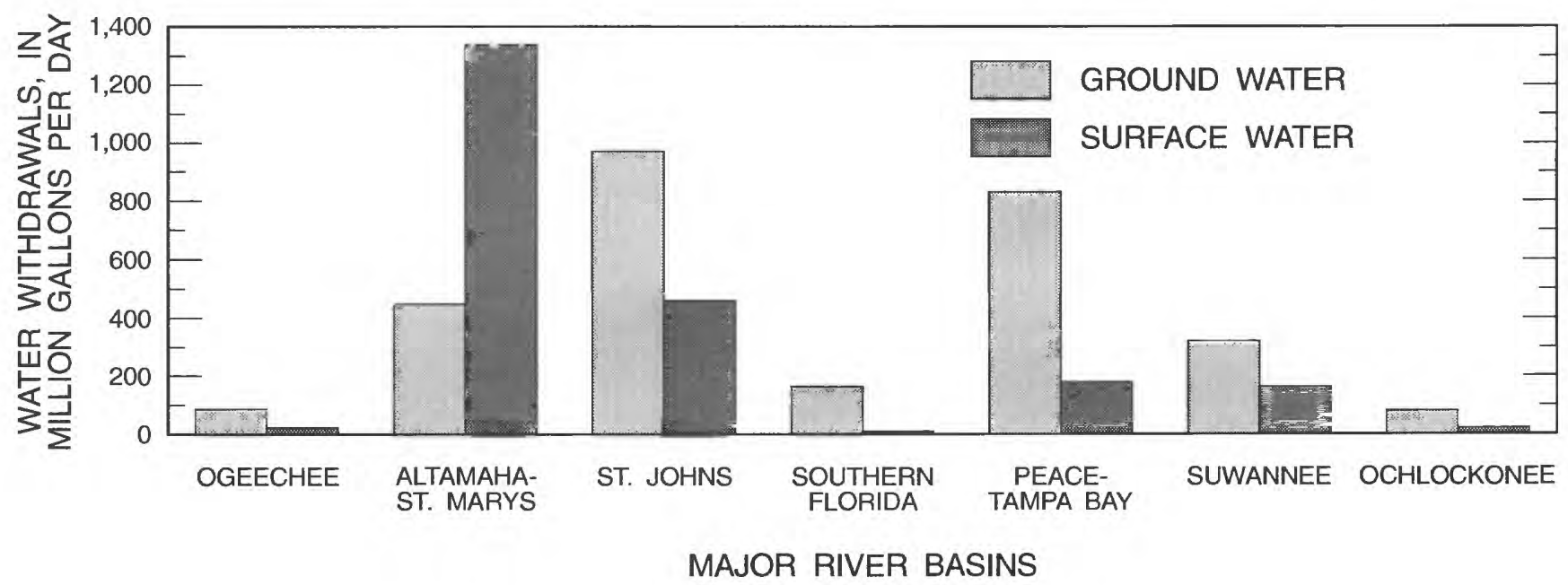

Figure 13. Ground- and surface-water withdrawals by major river basin in the Georgia-Florida Coastal Plain study unit, 1990. 
water withdrawn for the following categories: public supply, Upper St. Johns River (206 Mgal/d); selfsupplied domestic, Oklawaha River (23 Mgal/d); selfsupplied commercial-industrial, Peace River (96 $\mathrm{Mgal} / \mathrm{d}$ ); agriculture, Vero Beach Coastal (184 Mgal/d); thermoelectric power generation, Upper Oconee River (1,047 Mgal/d) (app. 2, table B). The Upper Ocmulgee River cataloging unit withdrew more than $74 \mathrm{Mgal} / \mathrm{d}$ for public supply, but imported an additional $104 \mathrm{Mgal} / \mathrm{d}$ from the Chattahoochee River.

\section{TREATED WASTEWATER DISCHARGE IN THE GEORGIA-FLORIDA COASTAL PLAIN STUDY UNIT}

Once water is withdrawn and used it either evaporates, transpires, is incorporated into products or crops, consumed by humans or livestock, or runs off as surface water or percolates into the ground. After being used, some water is collected and treated before being released. Treatment can be as simple as a settling process or as complete as advanced treatment. Treated wastewater discharged within the GeorgiaFlorida Coastal Plain study unit was estimated at nearly $1,187 \mathrm{Mgal} / \mathrm{d}$ in 1990 . This includes wastewater discharged by domestic (municipal) and industrial facilities, as well as releases from septic tanks. Of the total water treated, 58 percent was discharged as effluent directly into surface water and 42 percent was discharged to ground water. Surface-water disposal includes effluent outfalls into bays, rivers, streams, ditches, and wetlands. Ground-water disposal includes effluent discharges or releases through drain fields, injection wells, land application systems (spray fields and reuse systems), and percolation ponds. Pinellas and Orange Counties each discharged more than $100 \mathrm{Mgal} / \mathrm{d}$ of treated wastewater during 1990 (fig. 14). Discharge from powerplants, mining dewatering, or stormwater retention are not included in these wastewater discharge totals, primarily because this water is generally not treated and accurate or measured values are difficult to obtain.

\section{Domestic Discharges}

Domestic wastewater facilities are those systems that receive or dispose of municipal wastewater derived principally from residential dwellings, business or commercial buildings, institutions, and some industrial facilities (Florida Department of
Environmental Regulation, 1991). For this report, 744 domestic wastewater facilities were inventoried and and these served an estimated 5.1 million people (table 6). Pinellas, Hillsborough, Orange, and Duval Counties had the greatest number of people served by domestic wastewater facilities in the study unit. These four counties accounted for 60 percent of the population served by domestic wastewater facilities. Of the total number of systems inventoried, 571 systems were in Florida (app. 3, table A), and 223 systems were in Georgia (app. 3, table B). Most of these systems had a capacity of more than $0.04 \mathrm{Mgal} / \mathrm{d}$ or an actual discharge of more than $0.01 \mathrm{Mgal} / \mathrm{d}$ during 1990. Tables list design or permitted capacity and actual discharge as well as discharge method.

Domestic wastewater discharged in the GeorgiaFlorida Coastal Plain study unit totaled nearly $789 \mathrm{Mgal} / \mathrm{d}$. Approximately 61 percent $(484 \mathrm{Mgal} / \mathrm{d})$ of the water was discharged to surface water and 39 percent ( $305 \mathrm{Mgal} / \mathrm{d}$ ) was discharged to ground water. Land application systems (drain fields, percolation ponds, spray fields, and reuse irrigation systems) accounted for 75 percent of the water released to the ground while 25 percent was discharged directly through injection wells. Overall, 16 domestic wastewater facilities within the study unit discharged more than $10 \mathrm{Mgal} / \mathrm{d}$ during 1990 (fig. 15). Several large land application systems are located within the study unit. These include the Clayton County (Georgia) Water Authority, E.L. Huie Jr., Land Application Facility, and the City of Tallahassee, Southeast Spray Irrigation Field. The E.L Huie facility discharged about $14 \mathrm{Mgal} / \mathrm{d}$ of treated effluent in 1990 on 3,700 acres of pine forest (Clayton County Water Authority, undated) in southeastern Clayton County. The City of Tallahassee discharged about $12 \mathrm{Mgal} / \mathrm{d}$ of treated effluent in 1990 (Marella, 1994, p. 35) on 1,840 acres of cover crops including corn, sorghum, soybeans, and rye (Pruitt and others, 1988, p. 2). Two large reuse systems are also located within the study unit. These include the city of St. Petersburg, which used about $21 \mathrm{Mgal} / \mathrm{d}$ of treated wastewater effluent for irrigation (residential and commercial lawns, and parks and golf courses) throughout Pinellas County in 1990, and the city of Orlando, which used about $20 \mathrm{Mgal} / \mathrm{d}$ of treated wastewater effluent for the irrigation of citrus throughout Lake and Orange Counties in 1990. The City of St. Petersburg along with Pinellas County Water and Sewer each discharged about $20 \mathrm{Mgal} / \mathrm{d}$ of treated wastewater effluent in 1990 through injection 


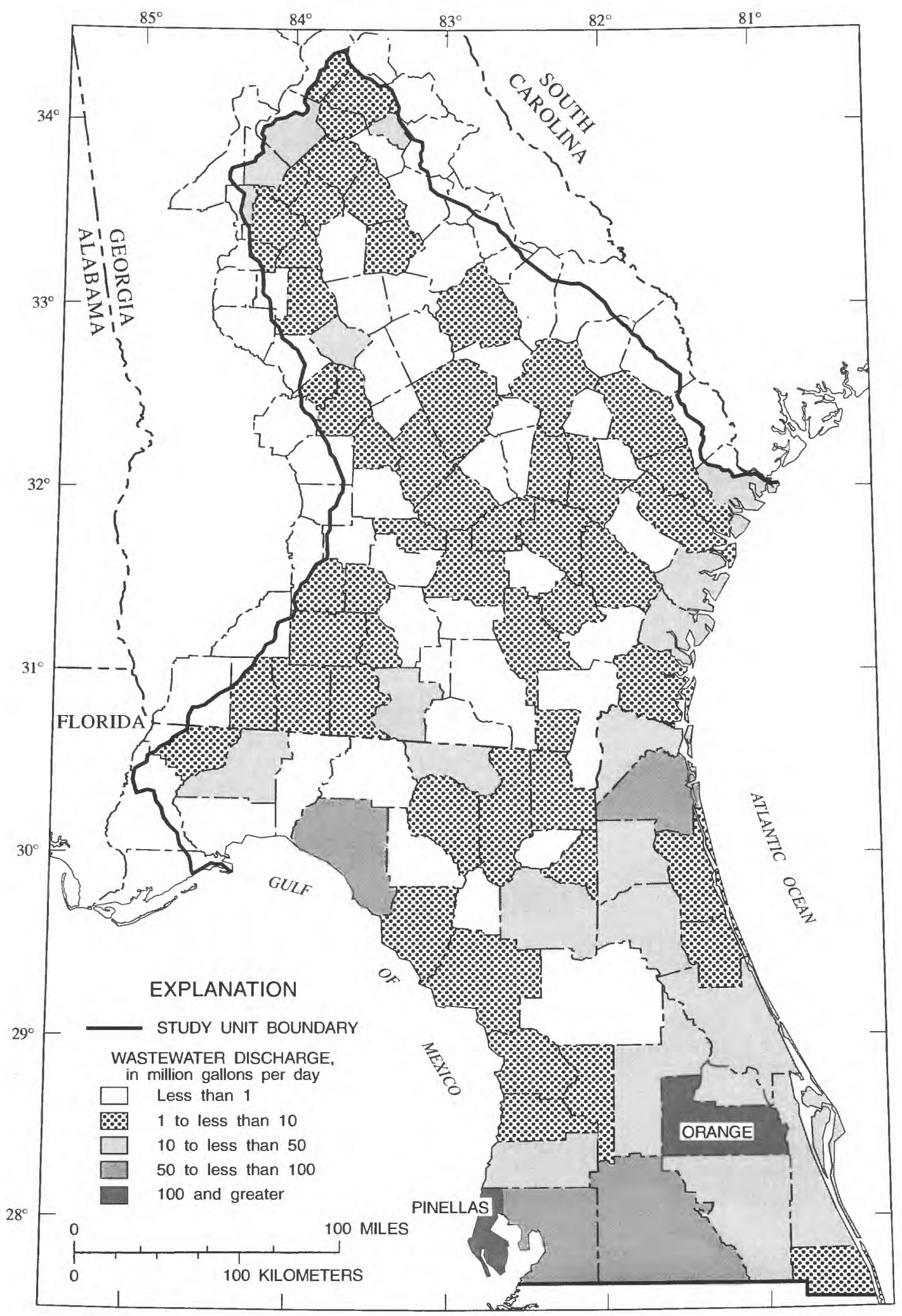

Figure 14. Treated wastewater discharge by county in the Georgia-Florida Coastal Plain study unit, 1990. 
Table 6. Estimated wastewater discharge, population served, and number of septic tanks by county in the Georgia-Florida study unit, 1990

[Modified from Marella. 1994, U.S. Bureau of Census, 1993a and 1993b; Mgal/d, million gallons per day; Fl, Florida; Ga, Georgia; Industrial wastewater data was unavailable for the counties in Georgia for 1990]

\begin{tabular}{|c|c|c|c|c|c|c|}
\hline \multirow[b]{2}{*}{ County } & \multicolumn{2}{|c|}{ Domestic wastewater } & \multicolumn{2}{|c|}{ Industrial wastewater } & \multicolumn{2}{|c|}{ Septic tanks } \\
\hline & $\begin{array}{c}\text { Number of } \\
\text { facilities }\end{array}$ & $\begin{array}{l}\text { Discharge } \\
\text { in Mgal/d }\end{array}$ & $\begin{array}{l}\text { Number of } \\
\text { facilities }\end{array}$ & $\begin{array}{l}\text { Discharge } \\
\text { in Mgal/d }\end{array}$ & $\begin{array}{c}\text { Number of } \\
\text { septic } \\
\text { tanks }\end{array}$ & $\begin{array}{l}\text { Releases } \\
\text { in Mgal/d }\end{array}$ \\
\hline Alachua $(\mathrm{Fl})$ & 10 & 14.83 & 1 & 0.60 & 21,074 & 2.95 \\
\hline Appling (Ga) & 0 & 0.00 & 0 & 0.00 & 4,613 & 0.65 \\
\hline Atkinson $(\mathrm{Ga})$ & 1 & 0.24 & 0 & 0.00 & 1,407 & 0.20 \\
\hline $\operatorname{Bacon}(\mathrm{Ga})$ & 1 & 0.33 & 0 & 0.00 & 2,226 & 0.31 \\
\hline Baker (Fl) & 3 & 0.81 & 0 & 0.00 & 4,474 & 0.63 \\
\hline Baldwin (Ga) & 1 & 4.84 & 0 & 0.00 & 5,753 & 0.81 \\
\hline Barrow (Ga) & 2 & 0.52 & 0 & 0.00 & 7,903 & 1.11 \\
\hline Ben Hill (Ga) & 1 & 3.09 & 0 & 0.00 & 2,557 & 0.36 \\
\hline Berrien (Ga) & 3 & 0.29 & 0 & 0.00 & 3,004 & 0.42 \\
\hline $\operatorname{Bibb}(\mathrm{Ga})$ & 3 & 27.27 & 0 & 0.00 & 9,077 & 1.27 \\
\hline Bleckley (Ga) & 1 & 0.39 & 0 & 0.00 & 2,358 & 0.33 \\
\hline Bradford (Fl) & 3 & 2.02 & 1 & 6.80 & 5,953 & 0.83 \\
\hline Brantley (Ga) & 1 & 0.01 & 0 & 0.00 & 3,904 & 0.55 \\
\hline Brevard (Fl) & 33 & 42.78 & 0 & 0.00 & 44,874 & 6.28 \\
\hline Brooks $(\mathrm{Ga})$ & 0 & 0.00 & 0 & 0.00 & 3,858 & 0.54 \\
\hline Bryan (Ga) & 2 & 0.65 & 0 & 0.00 & 3,843 & 0.54 \\
\hline Bulloch (Ga) & 1 & 4.02 & 0 & 0.00 & 8,873 & 1.24 \\
\hline Burke (Ga) (b) & 1 & 0.17 & 0 & 0.00 & 1,243 & 0.17 \\
\hline Butts (Ga) & 3 & 0.63 & 0 & 0.00 & 3,740 & 0.52 \\
\hline Camden (Ga) & 3 & 1.56 & 0 & 0.00 & 4,586 & 0.64 \\
\hline Candler (Ga) & 0 & 0.00 & 0 & 0.00 & 1,768 & 0.25 \\
\hline Charlton $(\mathrm{Ga})$ & 1 & 0.22 & 0 & 0.00 & 2,013 & 0.28 \\
\hline Chatham (Ga) (b) & 3 & 2.72 & 0 & 0.00 & 7,430 & 1.04 \\
\hline Citrus (Fl) & 16 & 2.57 & 0 & 0.00 & 35,490 & 4.97 \\
\hline Clarke (Ga) (b) & 3 & 10.72 & 0 & 0.00 & 7,183 & 1.01 \\
\hline Clay $(\mathrm{Fl})$ & 13 & 6.94 & 2 & 6.01 & 17,704 & 2.48 \\
\hline Clayton (Ga) (b) & 4 & 30.11 & 0 & 0.00 & 3,638 & 0.51 \\
\hline Clinch (Ga) & 1 & 0.67 & 0 & 0.00 & 1,100 & 0.15 \\
\hline Coffee (Ga) & 0 & 0.00 & 0 & 0.00 & 6,871 & 0.96 \\
\hline Colquitt (Ga) (b) & 4 & 2.96 & 0 & 0.00 & 7,359 & 1.03 \\
\hline Columbia (Fl) & 1 & 1.69 & 0 & 0.00 & 12,743 & 1.78 \\
\hline Cook (Ga) & 3 & 1.58 & 0 & 0.00 & 2,424 & 0.34 \\
\hline Crawford (Ga) (b) & 0 & 0.00 & 0 & 0.00 & 1,630 & 0.23 \\
\hline Crisp (Ga) (b) & 0 & 0.00 & 0 & 0.00 & 450 & 0.06 \\
\hline Decatur (Ga) (b) & 0 & 0.00 & 0 & 0.00 & 1,210 & 0.17 \\
\hline De Kalb (Ga) (b) & 3 & 29.74 & 0 & 0.00 & 11,850 & 1.66 \\
\hline Dixie (Fl) & 2 & 0.26 & 0 & 0.00 & 5,622 & 0.79 \\
\hline Dodge (Ga) & 3 & 0.91 & 0 & 0.00 & 4,517 & 0.63 \\
\hline Dooly (Ga) (b) & 0 & 0.00 & 0 & 0.00 & 690 & 0.10 \\
\hline Duval (Fl) & 22 & 68.03 & 5 & 9.77 & 65,114 & 9.12 \\
\hline Echols (Ga) & 0 & 0.00 & 0 & 0.00 & 881 & 0.12 \\
\hline Effingham (Ga) (b) & 0 & 0.00 & 0 & 0.00 & 1,890 & 0.26 \\
\hline
\end{tabular}


Table 6. Estimated wastewater discharge, population served, and number of septic tanks by county in the Georgia-Florida study unit, 1990 - Continued

[Modified from Marella, 1994, U.S. Bureau of Census, 1993a and 1993b; Mgal/d, million gallons per day; Fl, Florida; Ga, Georgia; Industrial wastewater data was unavailable for the counties in Georgia for 1990]

\begin{tabular}{|c|c|c|c|c|c|c|}
\hline \multirow[b]{2}{*}{ County } & \multicolumn{2}{|c|}{ Domestic wastewater } & \multicolumn{2}{|c|}{ Industrial wastewater } & \multicolumn{2}{|c|}{ Septic tanks } \\
\hline & $\begin{array}{c}\text { Number of } \\
\text { facilities }\end{array}$ & $\begin{array}{l}\text { Discharge } \\
\text { in Mgal/d }\end{array}$ & $\begin{array}{c}\text { Number of } \\
\text { facilities }\end{array}$ & $\begin{array}{l}\text { Discharge } \\
\text { in Mgal/d }\end{array}$ & $\begin{array}{c}\text { Number of } \\
\text { septic } \\
\text { tanks }\end{array}$ & $\begin{array}{l}\text { Releases } \\
\text { in MgaV/d }\end{array}$ \\
\hline Emanuel (Ga) & 2 & 1.38 & 0 & 0.00 & 4,672 & 0.65 \\
\hline Evans (Ga) & 0 & 0.00 & 0 & 0.00 & 2,065 & 0.29 \\
\hline Flagler (Fl) & 8 & 2.57 & 0 & 0.00 & 2,768 & 0.39 \\
\hline Franklin (Fl) (b) & 0 & 0.00 & 0 & 0.00 & 100 & 0.01 \\
\hline Fulton (Ga) (b) & 0 & 0.00 & 0 & 0.00 & 3,655 & 0.51 \\
\hline Gadsden (Fl) (b) & 5 & 1.09 & 1 & 3.07 & 6,800 & 0.95 \\
\hline Gilchrist (Fl) & 2 & 0.23 & 0 & 0.00 & 3,532 & 0.49 \\
\hline Glascock (Ga) (b) & 1 & 0.04 & 0 & 0.00 & 708 & 0.10 \\
\hline Glynn (Ga) & 3 & 8.10 & 0 & 0.00 & 9,897 & 1.39 \\
\hline Grady (Ga) (b) & 1 & 0.95 & 0 & 0.00 & 4,399 & 0.62 \\
\hline Greene (Ga) (b) & 3 & 0.63 & 0 & 0.00 & 2,480 & 0.35 \\
\hline Gwinnett $(\mathrm{Ga})(\mathrm{b})$ & 8 & 14.71 & 0 & 0.00 & 45,400 & 6.36 \\
\hline Hall (Ga) (b) & 0 & 0.00 & 0 & 0.00 & 7,700 & 1.08 \\
\hline Hamilton (Fl) & 3 & 0.68 & 1 & 16.65 & 2,198 & 0.31 \\
\hline Hancock (Ga) & 1 & 0.09 & 0 & 0.00 & 2,488 & 0.35 \\
\hline Henry (Ga) (b) & 10 & 1.82 & 0 & 0.00 & 13,860 & 1.94 \\
\hline Hernando (Fl) & 16 & 4.71 & 0 & 0.00 & 28,943 & 4.05 \\
\hline Hillsborough (Fl) & 49 & 79.43 & 8 & 5.46 & 78,911 & 11.05 \\
\hline Houston (Ga) (b) & 3 & 8.03 & 0 & 0.00 & 9,058 & 1.27 \\
\hline Indian River (Fl) & 16 & 4.55 & 1 & 0.25 & 19,360 & 2.71 \\
\hline Irwin $(\mathrm{Ga})$ & 0 & 0.00 & 0 & 0.00 & 2,097 & 0.29 \\
\hline Jackson (Ga) (b) & 4 & 1.09 & 0 & 0.00 & 8,505 & 1.19 \\
\hline Jasper (Ga) & 2 & 0.14 & 0 & 0.00 & 2,571 & 0.36 \\
\hline Jeff Davis (Ga) & 3 & 0.87 & 0 & 0.00 & 2,898 & 0.41 \\
\hline Jefferson (Fl) & 2 & 0.55 & 0 & 0.00 & 3,151 & 0.44 \\
\hline Jefferson (Ga) (b) & 3 & 0.34 & 0 & 0.00 & 2,662 & 0.37 \\
\hline Jenkins (Ga) (b) & 1 & 0.43 & 0 & 0.00 & 1,715 & 0.24 \\
\hline Johnson (Ga) & 1 & 0.36 & 0 & 0.00 & 2,344 & 0.33 \\
\hline Jones (Ga) & 1 & 0.16 & 0 & 0.00 & 5,791 & 0.81 \\
\hline Lafayette $(F l)$ & 2 & 0.12 & 0 & 0.00 & 1,849 & 0.26 \\
\hline Lake (Fl) & 32 & 7.99 & 3 & 0.56 & 36,188 & 5.07 \\
\hline $\operatorname{Lamar}(\mathrm{Ga})(\mathrm{b})$ & 1 & 0.63 & 0 & 0.00 & 2,040 & 0.29 \\
\hline Lanier $(\mathrm{Ga})$ & 1 & 0.18 & 0 & 0.00 & 1,260 & 0.18 \\
\hline Laurens (Ga) & 3 & 2.98 & 0 & 0.00 & 8,322 & 1.17 \\
\hline Leon $(F l)$ & 7 & 16.37 & 0 & 0.00 & 22,090 & 3.09 \\
\hline Levy (Fl) & 7 & 0.54 & 0 & 0.00 & 9,823 & 1.38 \\
\hline Liberty (Fl) (b) & 1 & 0.11 & 0 & 0.00 & 920 & 0.13 \\
\hline Liberty $(\mathrm{Ga})$ & 0 & 0.00 & 0 & 0.00 & 5,507 & 0.77 \\
\hline Long (Ga) & 1 & 0.02 & 0 & 0.00 & 2,021 & 0.28 \\
\hline Lowndes (Ga) & 5 & 7.11 & 0 & 0.00 & 9,723 & 1.36 \\
\hline Mc Intosh (Ga) & 0.23 & 0 & 0.00 & 3,279 & 0.46 & \\
\hline $\operatorname{Macon}(\mathrm{Ga})(\mathrm{b})$ & 0 & 0.00 & 0 & 0.00 & 130 & 0.02 \\
\hline Madison (Fl) & 1 & 0.63 & 0 & 0.00 & 4,528 & 0.63 \\
\hline Madison (Ga) (b) & 0 & 0.00 & 0 & 0.00 & 0 & 0.00 \\
\hline
\end{tabular}


Table 6. Estimated wastewater discharge, population served, and number of septic tanks by county in the Georgia-Florida study unit, 1990 - Continued

[Modified from Marella, 1994, U.S. Bureau of Census, 1993a and 1993b; Mgal/d, million gallons per day; Fl, Florida; Ga, Georgia; Industrial wastewater data was unavailable for the counties in Georgia for 1990]

\begin{tabular}{|c|c|c|c|c|c|c|}
\hline \multirow[b]{2}{*}{ County } & \multicolumn{2}{|c|}{ Domestic wastewater } & \multicolumn{2}{|c|}{ Industrial wastewater } & \multicolumn{2}{|c|}{ Septic tanks } \\
\hline & $\begin{array}{l}\text { Number of } \\
\text { facilities }\end{array}$ & $\begin{array}{l}\text { Discharge } \\
\text { in Mgal/d }\end{array}$ & $\begin{array}{l}\text { Number of } \\
\text { facilities }\end{array}$ & $\begin{array}{l}\text { Discharge } \\
\text { in } \mathrm{Mgal} / \mathrm{d}\end{array}$ & $\begin{array}{l}\text { Number of } \\
\text { septic } \\
\text { tanks }\end{array}$ & $\begin{array}{l}\text { Releases } \\
\text { in Mgal/d }\end{array}$ \\
\hline Marion (FI) & 30 & 6.83 & 0 & 0.00 & 59,532 & 8.33 \\
\hline Mitchell (Ga) (b) & 1 & 0.76 & 0 & 0.00 & 655 & 0.09 \\
\hline Monroe (Ga) (b) & 2 & 0.68 & 0 & 0.00 & 4,240 & 0.59 \\
\hline Montgomery (Ga) & 2 & 0.21 & 0 & 0.00 & 1,629 & 0.23 \\
\hline Morgan (Ga) & 3 & 0.58 & 0 & 0.00 & 3,076 & 0.43 \\
\hline Nassau (Fl) & 6 & 2.37 & 2 & 29.90 & 11,125 & 1.56 \\
\hline Newton (Ga) & 1 & 2.99 & 0 & 0.00 & 9,491 & 1.33 \\
\hline Oconee (Ga) & 0 & 0.00 & 0 & 0.00 & 5,591 & 0.78 \\
\hline Oglethorpe (Ga)(b) & 0 & 0.00 & 0 & 0.00 & 345 & 0.05 \\
\hline Orange (Fl) & 46 & 91.67 & 0 & 0.00 & 69,892 & 9.78 \\
\hline Osceola (Fl) & 19 & 10.22 & 0 & 0.00 & 13,903 & 1.95 \\
\hline $\operatorname{Pasco}(\mathrm{Fl})$ & 38 & 15.88 & 1 & 10.17 & 56,330 & 7.89 \\
\hline Peach (Ga) (b) & 2 & 0.39 & 0 & 0.00 & 3,268 & 0.46 \\
\hline Pierce (Ga) & 0 & 0.00 & 0 & 0.00 & 3,422 & 0.48 \\
\hline Pinellas (Fl) & 26 & 104.24 & 0 & 0.00 & 13,317 & 1.86 \\
\hline Polk (Fl) & 70 & 25.23 & 15 & 31.70 & 80,238 & 11.23 \\
\hline Pulaski (Ga) & 2 & 1.16 & 0 & 0.00 & 1,696 & 0.24 \\
\hline Putnam (Fl) & 4 & 2.47 & 1 & 37.22 & 24,850 & 3.48 \\
\hline Putnam (Ga) & 2 & 0.61 & 0 & 0.00 & 4,974 & 0.70 \\
\hline Rockdale (Ga) & 7 & 3.32 & 0 & 0.00 & 10,455 & 1.46 \\
\hline St. Johns (Fl) & 17 & 5.07 & 0 & 0.00 & 17,939 & 2.51 \\
\hline Screven $(\mathrm{Ga})(\mathrm{b})$ & 1 & 0.02 & 0 & 0.00 & 2,000 & 0.28 \\
\hline Seminole $(\mathrm{Fl})$ & 18 & 26.07 & 0 & 0.00 & 26,284 & 3.68 \\
\hline Spalding (Ga) (b) & 1 & 1.12 & 0 & 0.00 & 4,815 & 0.67 \\
\hline Sumter $(F \mathbf{l})$ & 8 & 0.84 & 0 & 0.00 & 11,638 & 1.63 \\
\hline Suwannee (Fl) & 4 & 0.78 & 1 & 1.00 & 8,792 & 1.23 \\
\hline Taliaferro (Ga)(b) & 1 & 0.01 & 0 & 0.00 & 0 & 0.00 \\
\hline Tattnall (Ga) & 3 & 0.65 & 0 & 0.00 & 3,926 & 0.55 \\
\hline Taylor (Fl) & 1 & 0.79 & 1 & 53.90 & 5,780 & 0.81 \\
\hline Telfair (Ga) & 5 & 0.87 & 0 & 0.00 & 2,056 & 0.29 \\
\hline Thomas (Ga) & 4 & 3.47 & 0 & 0.00 & 6.977 & 0.98 \\
\hline Tift (Ga) & 2 & 4.37 & 0 & 0.00 & 5,032 & 0.70 \\
\hline Toombs (Ga) & 4 & 2.25 & 0 & 0.00 & 3,878 & 0.54 \\
\hline Treutlen (Ga) & 1 & 0.30 & 0 & 0.00 & 1,286 & 0.18 \\
\hline Turner (Ga) (b) & 2 & 0.04 & 0 & 0.00 & 1,558 & 0.22 \\
\hline Twiggs (Ga) & 1 & 0.14 & 0 & 0.00 & 2,946 & 0.41 \\
\hline Union (Fl) & 2 & 0.43 & 0 & 0.00 & 1,899 & 0.27 \\
\hline Upson (Ga) (b) & 0 & 0.00 & 0 & 0.00 & 0 & 0.00 \\
\hline Volusia (Fl) & 25 & 29.82 & 2 & 0.06 & 60,843 & 8.52 \\
\hline Wakulla (Fl) & 3 & 0.10 & 0 & 0.00 & 5,645 & 0.79 \\
\hline Walton (Ga) & 5 & 2.14 & 0 & 0.00 & 7,931 & 1.11 \\
\hline Ware $(\mathrm{Ga})$ & 1 & 2.81 & 0 & 0.00 & 6,529 & 0.91 \\
\hline Warren (Ga) (b) & 3 & 0.33 & 0 & 0.00 & 920 & 0.13 \\
\hline Washington (Ga) & 2 & 1.11 & 0 & 0.00 & 4,065 & 0.57 \\
\hline
\end{tabular}


Table 6. Estimated wastewater discharge, population served, and number of septic tanks by county in the Georgia-Florida study unit, 1990 - Continued

[Modified from Marella, 1994. U.S. Bureau of Census, 1993a and 1993b; Mgal/d, million gallons per day; Fl, Florida; Ga, Georgia: Industrial wastewater data was unavailable for the counties in Georgia for 1990]

\begin{tabular}{|c|c|c|c|c|c|c|}
\hline \multirow[b]{2}{*}{ County } & \multicolumn{2}{|c|}{ Domestic wastewater } & \multicolumn{2}{|c|}{ Industrial wastewater } & \multicolumn{2}{|c|}{ Septic tanks } \\
\hline & $\begin{array}{l}\text { Number of } \\
\text { facilities }\end{array}$ & $\begin{array}{l}\text { Discharge } \\
\text { in Mgal/d }\end{array}$ & $\begin{array}{l}\text { Number of } \\
\text { facilities }\end{array}$ & $\begin{array}{l}\text { Discharge } \\
\text { in Mgal/d }\end{array}$ & $\begin{array}{c}\text { Number of } \\
\text { septic } \\
\text { tanks }\end{array}$ & $\begin{array}{l}\text { Releases } \\
\text { in Mgal/d }\end{array}$ \\
\hline Wayne (Ga) & 1 & 1.53 & 0 & 0.00 & 5,117 & 0.72 \\
\hline Wheeler (Ga) & 2 & 0.21 & 0 & 0.00 & 1,389 & 0.19 \\
\hline Wilcox (Ga) & 3 & 0.61 & 0 & 0.00 & 1,944 & 0.27 \\
\hline Wilkinson (Ga) & 1 & 0.27 & 0 & 0.00 & 3,008 & 0.42 \\
\hline Worth (Ga) (b) & 0 & 0.00 & 0 & 0.00 & 3,230 & 0.45 \\
\hline Totals & 744 & 789.19 & 46 & 213.12 & 1.318 .761 & 184.63 \\
\hline
\end{tabular}

wells into an unused part of a deep aquifer (Marella, 1994, p. 44). Pinellas, Hillsborough, Orange, and Duval Counties discharged the most treated effluent from domestic wastewater facilities (table 6) which accounted for 42 percent of the total discharged effluent in the study unit during 1990.

\section{Industrial Discharges}

Industrial wastewater facilities are those that produce, treat or dispose of wastewater not otherwise defined primarily as domestic wastewater; including the runoff and leachate from areas that receive contaminants associated with industrial or commercial storage, handling, or processing (Florida Department of Environmental Regulation, 1991). For this report, only industrial wastewater systems in Florida were inventoried because data for the systems in Georgia were not readily available at the time of this publication. Nearly all of these systems had a capacity of more than $0.04 \mathrm{Mgal} / \mathrm{d}$. In Florida, many of the industrial wastewater systems are permitted for large amounts of effluent discharge, but often discharge well below permitted capacities, discharge only seasonally, or do not discharge at all during a given year. This inventory did not include the discharge from the permitted thermoelectric power plants in Georgia or Florida that discharged water used for once-through cooling because it did not require treatment. Discharge from the dewatering and stormwater retention at the many mining operations in both States were also notincluded because much of this water does not require treatment and is most often unmeasured.

Industrial wastewater discharged in the Florida part of the Georgia-Florida Coastal Plain study unit totaled $213 \mathrm{Mgal} / \mathrm{d}$. Nearly all (99.9 percent) of the wastewater was discharged to surface water. In Florida, Nassau, Polk, Putnam, and Taylor Counties each discharged $30 \mathrm{Mgal} / \mathrm{d}$ or more of industrial wastewater during 1990 . The industrial wastewater discharged in Nassau, Putnam, and Taylor Counties is associated with the major pulp and paper manufacturing facilities, while the industrial wastewater discharged in Polk County is associated with foodprocessing facilities or chemical plants.

\section{Septic Tanks}

The use of septic tanks is common throughout the study unit, especially in rural areas. Septic tanks are mostly used for individual residents or small commercial establishments (churches, convenience stores, small motels, restaurants, and trailer parks, etc.) that are in rural or remote areas, or in urban areas that are not served by a domestic (municipal) wastewater facility. Water from septic tanks is generally released to the ground through a subsurface drain field (sometimes referred to as an absorption field) after natural biological treatment. In 1990, more than 1.3 million septic tanks were estimated in use within the study unit (U.S. Bureau of Census, 1993a and 1993b). These systems served nearly 4.2 million people in 1990. However, concentrations of septic tanks are common in highly urbanized counties, as housing growth often occurs in unincorporated areas surrounding larger cities (Marella, 1994 and Ayres Associates, 1987). Sometimes, these areas are not served by domestic wastewater (sewer) facilities. Of the four counties that had the most number of septic tanks in the study unit for 1990 (table 6), Polk, Hillsborough, 


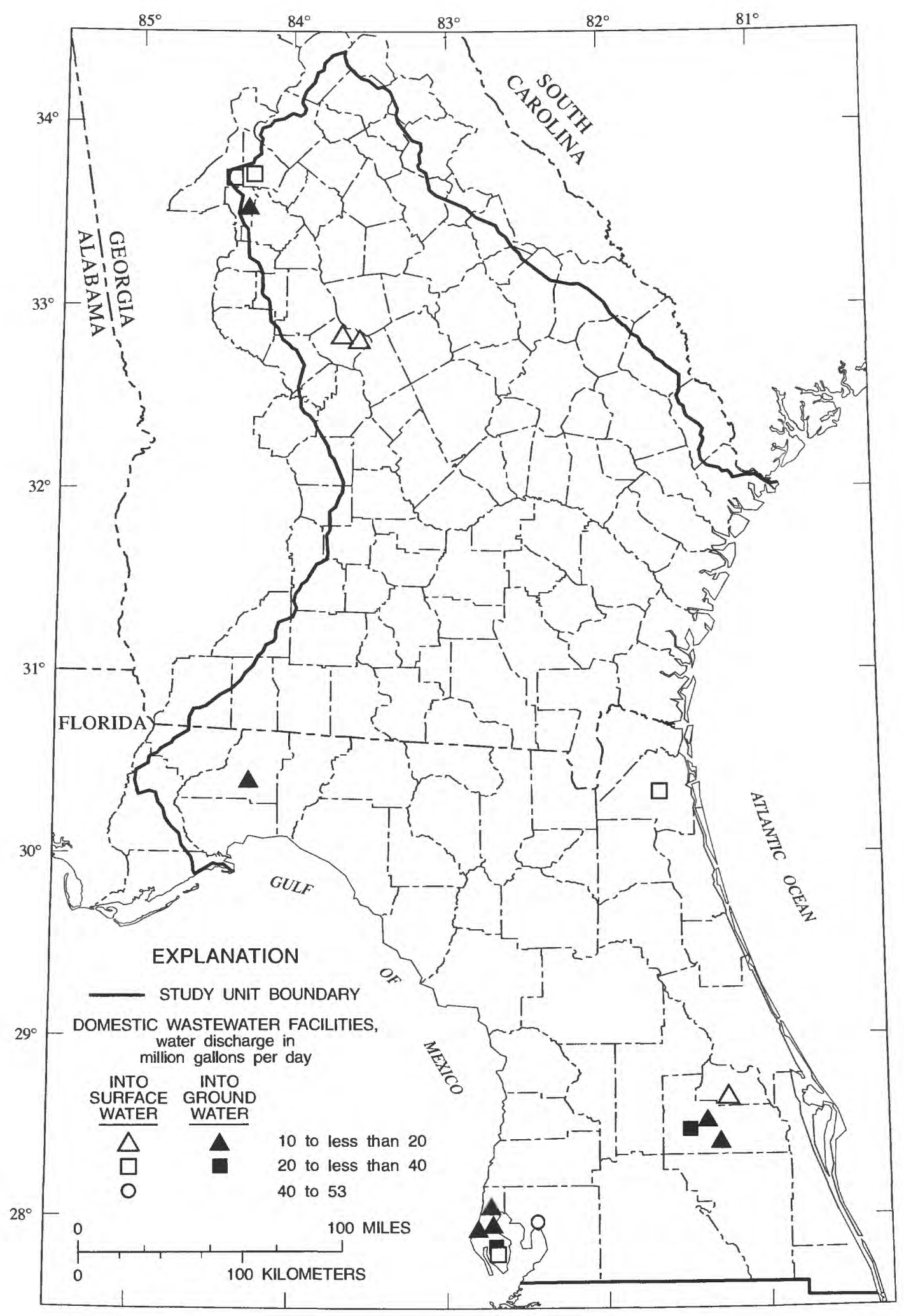

Figure 15. General locations of the largest domestic wastewater facilities in the Georgia-Florida Coastal Plain study unit, 1990. 
Orange and Duval Counties all were located in the same county with a major city Lakeland, Tampa, Orlando, and Jacksonville, respectively. The density of the septic tanks in three of these areas are among the highest in Florida in 1990. The density of septic tanks in Duval County was 84 per $\mathrm{mi}^{2}$, Hillsborough County was about 75 per $\mathrm{mi}^{2}$, and Orange County was 77 per $\mathrm{mi}^{2}$ (Marella, 1994, p. 15). In Georgia, the counties with the highest density of septic tanks are also those that are in the Atlanta area. The density of septic tanks was highest in Gwinnett (140 per $\mathrm{mi}^{2}$ ), Fulton (122 per $\left.\mathrm{mi}^{2}\right)$, Rockdale (79 per $\left.\mathrm{mi}^{2}\right)$, and DeKalb (69 per mi ${ }^{2}$ ) Counties for 1990 . However, because a large part of each of these counties is served by domestic wastewater facilities, the actual density of the septic tanks in the areas not served by domestic wastewater factilities is even greater. For those counties that were not entirely within the study unit, estimates of the number of septic tanks were based on the percentage of population in the county within the study unit.

Based on an average discharge of $55 \mathrm{gal} / \mathrm{d}$ (gallons per day) per person and 2.5 people per household, estimated water released from each septic tank would be about $140 \mathrm{gal} / \mathrm{d}$ (Tchobanoglous, 1991). Discharge from the 1.3 million septic tanks in the study unit for 1990 was approximately $185 \mathrm{Mgal} / \mathrm{d}$. Most of the effluent is released to the soils through on-site subsurface drain fields that allow the water from the tank to percolate into the ground (usually into the surficial aquifers) or transpire to the atmosphere through surface vegetation. Polk and Hillsborough Counties had releases of treated effluent from septic tanks of more than $10 \mathrm{Mgal} / \mathrm{d}$ in 1990 (table 6).

\section{SUMMARY}

The Georgia-Florida Coastal Plain study unit covers approximately 62,000 square miles in the Southeastern United States. Located within the Georgia-Florida Coastal Plain study unit are all or part of 7 major river basins; the Ogeechee, AltamahaSt. Marys, St. Johns, Southern Florida, Peace-Tampa Bay, Suwannee, and the Ochlockonee. Only the Altamaha-St. Marys, Ochlockonee, Ogeechee, and the Suwannee basin's are entirely within the study unit, as the other 3 (St. Johns, Southern Florida, and PeaceTampa Bay) are only partially in the study unit. The total population in the study unit for 1990 was estimated at 9.3 million. Located within the study unit are all or part of 4 of the Nation's top 50 most populated metropolitan statistical areas in 1990; Atlanta, Jacksonville, Orlando, and Tampa-St. PetersburgClearwater. Economic activities in the study unit include agriculture, commercial services, lumber and food processing, manufacturing (pulp and paper, textiles, electronics), mining (limerock and phosphate), transportation, and tourism.

Estimated freshwater withdrawn in the GeorgiaFlorida Coastal Plain study unit during 1990 was nearly $5,075 \mathrm{Mgal} / \mathrm{d}$. Throughout this area of Georgia and Florida, ground water is the primary source of water. Ground water accounted for more than 57 percent $(2,888 \mathrm{Mgal} / \mathrm{d})$ of the water withdrawn in 1990 . The Floridan aquifer system provided nearly 91 percent $(2,630 \mathrm{Mgal} / \mathrm{d})$ of the ground water withdrawn in the study unit during 1990. Several other aquifers in the study unit are tapped for ground water. Surficial aquifers throughout the study unit supplied about 3 percent of the ground water withdrawn. The other aquifers include the Intermediate aquifer system in Florida, the Upper and Lower Brunswick aquifers and the Claiborne, Cretaceous, and Crystalline Rock aquifers in Georgia accounted for the remaining 6 percent. The St. Johns River basin accounted for the largest amount of ground water withdrawn in 1990 (34 percent), followed by the Peace-Tampa Bay basin (29 percent).

Surface water accounted for nearly 43 percent $(2,187 \mathrm{Mgal} / \mathrm{d})$ of the water withdrawn in the study unit during 1990. Nearly 49 percent of the surface water used in the study unit was withdrawn from the Oconee River, primarily for thermoelectric power generation. Significant amounts of surface water were also withdrawn from the Altamaha, Hillsborough, Ocmulgee, St. Johns, and Suwannee Rivers during 1990. Surface water supplied 33 percent ( 1.7 million) of the study units population served by public supply in 1990. The Altamaha-St. Marys River basin accounted for the largest amount of surface water withdrawn in 1990 (61 percent), followed by the St. Johns River basin (21 percent).

Water withdrawn for public supply in the study unit in 1990 totaled about $1,139 \mathrm{Mgal} / \mathrm{d}$, of which 83 percent ( $954 \mathrm{Mgal} / \mathrm{d})$ was ground water and 17 percent $(191 \mathrm{Mgal} / \mathrm{d})$ was surface water. Ground water is the primary source for public-supply water in central and northern Florida as well as southeastern Georgia. The Floridan aquifer system supplied 94 percent (893 Mgal/d) of the ground water withdrawn for 
public supply in the study unit. The Hillsborough River supplied 40 percent ( $76 \mathrm{Mgal} / \mathrm{d}$ ) and the Ocmulgee and Oconee Rivers each supplied about 12 percent of the surface water withdrawn for public supply in the study unit. Water withdrawn for self-supplied domestic use in the study unit in totaled $230 \mathrm{Mgal} / \mathrm{d}$ in 1990. This water is derived almost exclusively from ground water. The Floridan aquifer system supplied 65 percent $(151 \mathrm{Mgal} / \mathrm{d})$ of the ground water withdrawn for self-supplied domestic use in the study unit, the surficial aquifers 21 percent, and other aquifers 14 percent. Ground water supplied drinking water to 77 percent (5.8 million) of the study unit's population served by public supply and 100 percent ( 1.8 million) of the study unit's self-supplied population.

Water withdrawn for self-supplied commercialindustrial use (including mining) in the study unit in 1990 totaled about $862 \mathrm{Mgal} / \mathrm{d}$, of which 93 percent was ground water and 7 percent was surface water. The majority of the water withdrawn for self-supplied commercial-industrial use (63 percent) was for industrial manufacturing or processing, 31 percent for mining uses, and 6 percent for commercial needs. Water withdrawn for agriculture use (including water used for irrigation, livestock, fish farming, and frost or freeze protection) in the study unit in 1990 totaled $1,293 \mathrm{Mgal} / \mathrm{d}$. Ground water is the primary source of water for agricultural needs ( 69 percent) throughout the study unit and the surface water withdrawn (31 percent) was predominately obtained from unnamed canals or ditches, local lakes or ponds, or small creeks or tributaries. An estimated 1.25 million acres were irrigated within the study unit, 76 percent by low pressure and sprinkler irrigation systems, and 24 percent by flood irrigation systems. Water withdrawn for thermoelectric power generation in the study unit in 1990 totaled nearly $1,552 \mathrm{Mgal} / \mathrm{d}$, of which 99 percent was surface water and 1 percent was ground water. An additional $6,919 \mathrm{Mgal} / \mathrm{d}$ of saline surface water was withdrawn in the study unit for thermoelectric power generation during 1990, and was exclusively used for once-through cooling purposes.

Treated wastewater discharged within the Georgia-Florida Coastal Plain study unit was estimated at nearly $1,187 \mathrm{Mgal} / \mathrm{d}$. Of the total water treated, 58 percent was discharged directly to surface water and 42 percent was discharged to ground water. Surface-water disposal includes effluent outfalls into bays, rivers, streams, ditches, and wetlands. Groundwater disposal includes effluent discharges or releases through drain fields, injection wells, land application systems (spray fields and reuse systems), and percolation ponds. Domestic wastewater discharged in the study unit totaled nearly $789 \mathrm{Mgal} / \mathrm{d}$, industrial wastewater discharge totaled $213 \mathrm{Mgal} / \mathrm{d}$, and releases from septic tanks totaled nearly $185 \mathrm{Mgal} / \mathrm{d}$. An estimated 1.3 million septic tanks were in use within the study unit during 1990, and these systems served nearly 4.2 million people. Based on an average discharge of $55 \mathrm{gal} / \mathrm{d}$ per person per day and 2.5 people per household, water released from each septic tank would be about $140 \mathrm{gal} / \mathrm{d}$.

\section{SELECTED REFERENCES}

Akioka, L. M., 1990, Georgia statistical abstract, 1990-91: Athens, University of Georgia, College of Business Administration, $483 \mathrm{p}$.

1992, Georgia statistical abstract, 1992-93: Athens, University of Georgia, College of Business Administration, $535 \mathrm{p}$.

Atlanta Regional Commission, 1992, Water resources of the Atlanta region: Atlanta, April 1992, 1 sheet.

Ayres Associates, 1987, The impact of Florida's growth on the use of onsite sewage disposal systems: Tampa, Report to the Florida Department of Health and Rehabilitative Services, October, 1987, p. 59

Bachtel, D.C., and Boatright, S.R., 1994, The Georgia County Guide, tenth edition: Athens, Univeristy of Georiga, Department of Housing and Consumer Economics, Collegue of Family and Consumer Services, $200 \mathrm{p}$.

Berndt, M.P., Oaksford, E.T., Darst, M.R., and Marella, R.L., in press, Environmental setting and factors that affect water quality in the Georgia-Florida Coastal Plain study unit: U.S. Geological Survey WaterResources Investigations Report 95-4268.

Buros, O.K., 1989, Desalting practices in the United States: American Water Works Association Journal, v. 18, no. 11 , November, p. 38-42.

Campbell, K.M., 1986, The industrial minerals of Florida: Tallahassee, Florida Bureau of Geology Information Circular No. 102, 94 p.

Clarke, J.S., and Pierce, R.R., 1985, Georgia ground-water resources, in Moody, D.W., and others, compilers,National Water Summary 1984--Hydrologic events, selected water-quality trends, and ground-water resources: U.S. Geological Survey Water-Supply Paper 2275, p. 179-184.

Clayton County Water Authority, undated, E.L. Huie, Jr., Land Application Facility: Marrow, Ga., Clayton County Water Authority, $14 \mathrm{p}$. 
Dietrich, T.S., 1978, The urbanization of Florida's population: An historical perspective of county growth 18301970: Gainesville, University of Florida, Bureau of Economic and Business Research, 211 p.

Dykes, G.M., and Conlon, W.J., 1989, Use of membrane technology in Florida: American Water Works Association Journal, v. 18, no. 11, November, p. 43-46.

Fanning, J.L., Doonan, G.A., and Montgomery, L.T., 1992, Water use in Georgia by county for 1990: Atlanta, Georgia Geologic Survey Information Circular 90, $116 \mathrm{p}$.

Fanning, J.L., Doonan, G.A., Trent, V.P., and McFarlane, R.D., 1991, Power generation and related water use in Georgia: Atlanta, Georgia Geologic Survey Information Circular 87, $112 \mathrm{p}$.

Fernald, E.A., and Patton, D.J., 1984, Water resources atlas of Florida: Tallahassee, Florida State University, 291 p.

Florida Department of Environmental Regulation, 1990, Drinking water standards, monitoring, and reporting: Chap. 17-550, 48 p.

1991, Domestic wastewater facilities: Chap. 17$600,70 \mathrm{p}$.

Georgia Department of Natural Resources, 1984, Water availability and use, Altamaha-St. Marys River basin Georgia, 1984: Atlanta, Georgia Environmental Protection Division, 99 p.

1986, Water availability and use, Savannah River basin, Georgia, 1986: Atlanta. Georgia Environmental Protection Division, 95 p.

Hayes, L.R., Maslia, M.L., and Meeks, W.C., 1983, Hydrology and model evaluation of the principal artesian aquifer, Dougherty Plain, Southwest Georgia: Atlanta, Georgia Geologic Survey Bulletin 97, 93 p.

Hirsch, R.M.. Alley, W.M., and Wilber, W.G., 1988, Concepts for a national water-quality assessment program: U.S. Geological Survey Circular 1021, 42 p.

Holder, W.H., and Schretter, H.A., 1986, The atlas of Georgia: Athens, University of Georgia, Institute of Community and Area Development, 273 p.

Holland, T.W., 1992, Water-use data collection techniques in the southeastern United States, Puerto Rico, and the U.S. Virgin Islands: Little Rock, Ark., U.S. Geological Survey Water-Resources Investigations Report 92-4028, 76 p.

Hughes, G.H., 1975, Perspective on use of fresh water for cooling systems of thermoelectric powerplants in Florida: U.S. Geological Survey Water-Resources Investigations $43-75,30 \mathrm{p}$.

Izuno, F.T., and Haman, D.Z., 1987, Basic irrigation terminology: Gainesville, University of Florida, Institute of Food and Agricultural Sciences, Agricultural Engineering Fact Sheet AE-66, 4 p.

Kantrowitz, I.H., 1991, National Water-Quality Assessment Program - The Georgia-Florida Coastal Plain: U.S. Geological Survey Open-File Report 91-152, 2 p.
Leach, S.D., 1983, Source, use, and disposition of water in Florida, 1980: U.S. Geological Survey WaterResources Investigations Report 82-4090, 337 p.

Libbey, M.M., 1991, Another road story: net migration in Georgia: in Georgia Business and Economic Conditions: Athens, University of Georgia, Selig Center for Economic Growth, vol. 51, no. 5, 16 p.

Marella, R.L., 1988, Water withdrawals, use and trends in Florida, 1985: U.S. Geological Survey WaterResources Investigations Report 88-4103. 43 p. 1990a, Florida water-supply and use: in Carr, J.E., and others, compilers, National water summary 1987-Hydrologic events and water supply and use: U.S. Geological Survey Water-Supply Paper 2350, p. 207214.

1990b, Public-supply water use in Florida, 1987: U.S. Geological Survey Open-File Report 90-596, $39 \mathrm{p}$.

- 1992a, Factors that affect public-supply water use in Florida with a section on projected water use to the year 2020: U.S. Geological Survey Water-Resources Investigations Report 91-4123, 35 p.

1992b, Water withdrawals, use and trends in Florida, 1990: U.S. Geological Survey Water-Resources Investigations Report 92-4140, $38 \mathrm{p}$.

1993, Public-supply water use in Florida, 1990: U.S. Geological Survey Open-File Report 93-134, $46 \mathrm{p}$.

1994, Estimated discharge of treated wastewater in Florida, 1990: U.S. Geological Survey Open-File Report 93-364, $53 \mathrm{p}$.

1995, Water-use data by category, county, and water management district in Florida, 1950-90: U.S. Geological Survey Water-Resources Investigations Report 94-521, 88 p.

Marella, R.L., Fanning. J.L., and Mooty, W.S., 1993, Estimated use of water in the ApalachicolaChattahoochee-Flint River basin during 1990, and trends in water use from 1970 to 1990: U.S. Geological Survey Water-Resources Investigations Report 93-4084, 45 p.

Pierce, R.R., 1990, Georgia water-supply and use: in Carr, J.E., and others, compilers, National water summary 1987--Hydrologic events and water supply and use: U.S. Geological Survey Water-Supply Paper 2350, p. 215-222.

Pierce. R.R., Barber, N.L., and Stiles, H.R., 1982, Water use in Georgia by county for 1980: Atlanta, Georgia Geologic Survey Information Circular 59, $180 \mathrm{p}$.

1984, Georgia irrigation, 1970-80: A decade of growth: U.S. Geological Survey Water-Resources Investigations Report 83-4177, 29 p. 
Pruitt, J.B., Elder, J.F., Johnson, I.K., 1988, Effects of treated municipal effluent irrigation on ground water beneath sprayfields, Tallahassee, Florida: U.S. Geological Survey Water-Resources Investigations Report 88-4092, $35 \mathrm{p}$.

Purdom, E.D., and Anderson, J.R., Jr., 1988, Florida County atlas and municipal fact book: Tallahassee, Florida State University, Institute of Science and Public Affairs, $145 \mathrm{p}$.

Seaber, P.R., Kapinos, F.P., and Knapp, G.L., 1987, Hydrologic unit maps: U.S. Geological Survey Water-Supply Paper 2294, 63 p.

Smajstrla, A.G., Boman, B.J., Clark, G.A., Haman, D.Z., Harrison, D.S., Izuno, F.T., Zazueta, F.S., 1988, Efficiencies of Florida agricultural irrigation systems: Gainesville, University of Florida, Institute of Food and Agricultural Sciences, Bulletin 247, 15 p.

Solley, W.B., Chase, E.B., and Mann, W.B., 1983,

Estimated use of water in the United States in 1980: U.S. Geological Survey Circular 1001, 56 p.

Solley, W.B., Merk, C.F., and Pierce, R.R., 1988, Estimated use of water in the United States in 1985: U.S. Geological Survey Circular 1004, 82 p.

Solley, W.B., Pierce, R.R., and Perlman, H.A., 1993, Estimated use of water in the United States in 1990: U.S. Geological Survey Circular 1081, 76 p.

South Florida Water Management District, 1990, Desalination: An additional water source for South Florida: West Palm Beach, The Office of Communications, (PIO 276290 5M), 4 p.

Tchobanoglous, George, 1991, Wastewater engineering, treatments, disposal, and reuse ( 3 rd ed.): New York, Metcalf and Eddy, Inc. 2010 p.

Thompson, M.T., 1988, Forest statistics for southwest Georgia, 1988: Asheville, N.C., U.S. Department of Agricultural, Forest Service, Resource Bulletin SE-102, 53 p.

Trent, V.P., Fanning, J.L., and Doonan, G.A., 1990, Water use in Georgia by county for 1987: Atlanta, Georgia Geologic Survey Information Circular 85, 112 p.
Turlington, M.C., Fanning. J.L., and Doonan, G.A., 1987, Water use in Georgia by county for 1985: Atlanta, Georgia Geologic Survey Information Circular 81, $109 \mathrm{p}$.

U.S. Bureau of Census, 1991a. Statistical abstract of the United States, 1991 (11 I th ed.): Washington D.C., United States Department of Commerce, Bureau of the Census, 986 p.

- 1991b, Census of population and housing, 1990:

PUBLIC LAW (P.L.) 94-171. Data (State of Florida)

[machine-readable data files], prepared by the United

States Department of Commerce, Bureau of the

Census, Washington, D.C.

1991c, Census of population and housing, 1990:

PUBLIC LAW (P.L.) 94-171. Data (State of Georgia) [machine-readable data files], prepared by the United States Department of Commerce. Bureau of the Census, Washington, D.C.

- 1993a, 1990 Census of housing, detailed housing characteristics; Florida: Washington D.C., United States Department of Commerce, Bureau of the Census, CH-2-11, 793 p.

1993b, 1990 Census of housing, detailed housing characteristics; Georgia: Washington D.C., United States Department of Commerce, Bureau of the Census, CH-2-12, 506 p.

U. S. Geological Survey, 1975, Hydrologic unit map-1974, State of Florida: United States Geological Survey, 1:500,000 scale.

-1975, Hydrologic unit map-1974, State of Georgia: United States Geological Survey, 1:500,000 scale.

University of Florida, 1991, Florida population: Census summary 1990: Gainesville, University of Florida, Bureau of Economic and Business Research, $55 \mathrm{p}$.

Vecchioli, John and Foose, D.W., 1985, Florida groundwater resrouces, in Moody, D.W., and others, compilers, National Water Summary 1984--Hydrologic events, selected water-quality trends, and groundwater resources: U.S. Geological Survey WaterSupply Paper 2275, p. 173-178. 
APPENDIXES 
42 National Water Quality Assessment of the Georgia-Florida Coastal Plain Study Unit-Water Withdrawals and Treated Wastewater Discharges, 1990 
Appendix 1. Public-supply water use by utility in the Georgia-Florida Coastal Plain study unit, 1990 This appendix is divided into the following sections: A. Within Florida. B. Within Georgia.

[A. Florida. [Modified from Marella, 1993; Mgal/d, million gallons per day; FAS, Floridan aquifer system; Ut., utility; MHP, mobile home park; S/D, sub division; USA, unnamed surficial aquifers; GDU, General Developement Utilities; W/A, water association; SSU, Southern States Utilities: WRWSA, Withlacoochee Regional Water Supply Authority; Ser., service; W/S, water system; Co., county; WCRWSA, West Coast Regional Water Supply Authority; UIF, Utilities Incorporated of Florida; Vil., village; Comm., commission; MHU, Mad Hatter Utilities; PCU, Pasco County Utilities; N/A, not available; WF, wellfield; Ent., enterprises; PCWS. Pinellas County Water System: PCBoCC, Polk County Board of County Commissioners; WFC, West Florida Community; Bch., Beach; Riv., River]

\begin{tabular}{|c|c|c|c|c|c|c|}
\hline \multirow{2}{*}{ Utility/Owner } & \multirow{2}{*}{ County } & \multirow{2}{*}{ Cataloging unit } & \multicolumn{2}{|c|}{ Water source } & \multirow{2}{*}{$\begin{array}{c}1990 \\
\text { Mgal/d }\end{array}$} & \multirow{2}{*}{$\begin{array}{c}1990 \\
\text { Population } \\
\text { served }\end{array}$} \\
\hline & & & Name & Percent & & \\
\hline Alachua, city of & Alachua & Santa Fe River & FAS & 100 & 0.64 & 4,962 \\
\hline Archer, town of & Alachua & Oklawaha River & FAS & 100 & 0.19 & 1,372 \\
\hline Arredondo Utilities & Alachua & Oklawaha River & FAS & 100 & 0.11 & 1,675 \\
\hline Gainesville Regional Ut. & Alachua & Oklawaha River & FAS & 100 & 20.32 & 123,790 \\
\hline Hawthorne, city of & Alachua & Oklawaha River & FAS & 100 & 0.24 & 1,305 \\
\hline High Springs, city of & Alachua & Santa Fe River & FAS & 100 & 0.38 & 3,144 \\
\hline Kincaid Hills Utilities & Alachua & Oklawaha River & FAS & 100 & 0.10 & 1,000 \\
\hline Micanopy, town of & Alachua & Oklawaha River & FAS & 100 & 0.08 & 612 \\
\hline Newberry, city of & Alachua & Waccasassa River & FAS & 100 & 0.26 & 1,644 \\
\hline Oak Park MHP & Alachua & Oklawaha River & FAS & 100 & 0.09 & 620 \\
\hline Turkey Creek Utilities & Alachua & Santa Fe River & FAS & 100 & 0.41 & 688 \\
\hline Waldo, city of & Alachua & Santa Fe River & FAS & 100 & 0.10 & 962 \\
\hline West Gate MHP & Alachua & Santa Fe River & FAS & 100 & 0.03 & 330 \\
\hline Macclenny, city of & Baker & St. Marys River & FAS & 100 & 0.79 & 3,966 \\
\hline Macclenny S/D & Baker & St. Marys River & FAS & 100 & 0.02 & 136 \\
\hline Brooker, town of & Bradford & Santa Fe River & FAS & 100 & 0.04 & 355 \\
\hline Geneva Lake Estates & Bradford & Santa Fe River & FAS & 100 & 0.04 & 300 \\
\hline Hampton, town of & Bradford & Santa Fe River & FAS & 100 & 0.06 & 351 \\
\hline Keystone Club Estates & Bradford & Santa Fe River & FAS & 100 & 0.16 & 362 \\
\hline Lawtey, city of & Bradford & Santa Fe River & FAS & 100 & 0.18 & 739 \\
\hline Starke, city of & Bradford & Santa Fe River & FAS & 100 & 1.13 & 5,226 \\
\hline Aquarina Utilities & Brevard & Cape Canaveral Coastal & FAS & 100 & 0.08 & 170 \\
\hline Avatar Utilities & Brevard & Cape Canaveral Coastal & USA & 100 & 0.76 & 6,340 \\
\hline Cocoa Water Department & Brevard & Upper St. Johns River & FAS & 100 & 23.52 & 139,672 \\
\hline Melbourne, city of & Brevard & Upper St. Johns River & Lake Washington & 100 & 16.24 & 136,490 \\
\hline North Brevard Utilities & Brevard & Cape Canaveral Coastal & FAS & 100 & 0.65 & 7,000 \\
\hline GDU - Palm Bay & Brevard & Cape Canaveral Coastal & USA and FAS & $98 / 2$ & 4.38 & 33,500 \\
\hline South Brevard Utilities & Brevard & Cape Canaveral Coastal & FAS & 100 & 0.06 & 500 \\
\hline Titusville, city of & Brevard & Cape Canaveral Coastal & FAS & 100 & 5.62 & 39,394 \\
\hline Cinnamon Ridge Utility & Citrus & Crystal - Pithlachasotte & FAS & 100 & 0.04 & 390 \\
\hline Connell Lake Estates & Citrus & Crystal - Pithlachasotte & FAS & 100 & 0.14 & 150 \\
\hline Crystal River, city of & Citrus & Crystal - Pithlachasotte & FAS & 100 & 0.74 & 4,307 \\
\hline Floral City W/A & Citrus & Withlacoochee River & FAS & 100 & 0.23 & 2,638 \\
\hline Greenbrair Condo W/A & Citrus & Crystal - Pithlachasotte & FAS & 100 & 0.07 & 295 \\
\hline Homosassa Water District & Citrus & Crystal - Pithlachasotte & FAS & 100 & 0.77 & 3.659 \\
\hline Inverness, city of & Citrus & Withlacoochee River & FAS & 100 & 1.03 & 7,078 \\
\hline Marion Utilities & Citrus & Withlacoochee River & FAS & 100 & 0.01 & 25 \\
\hline Ozello W/A & Citrus & Withlacoochee River & FAS & 100 & 0.27 & 2,919 \\
\hline P.P.F. Incorporated & Citrus & Withlacoochee River & FAS & 100 & 0.04 & 272 \\
\hline Rolling Oaks Utilities & Citrus & Withlacoochee River & FAS & 100 & 2.80 & 11,493 \\
\hline Royal Oaks at Inverness & Citrus & Withlacoochee River & FAS & 100 & 0.02 & 106 \\
\hline SSU: Apache Shores & Citrus & Withlacoochee River & FAS & 100 & 0.01 & 738 \\
\hline SSU: Citrus Springs & Citrus & Withlacoochee River & FAS & 100 & 0.52 & 3,550 \\
\hline SSU: Golden Terrace & Citrus & Withlacoochee River & FAS & 100 & 0.02 & 268 \\
\hline
\end{tabular}


Appendix 1. Public-supply water use by utility in the Georgia-Florida Coastal Plain study unit, 1990 —Continued This appendix is divided into the following sections: A. Within Florida. B. Within Georgia.

[A. Florida. [Modified from Marella, 1993; Mgal/d, million gallons per day; FAS, Floridan aquifer system; Ut., utility; MHP, mobile home park; S/D, sub division; USA, unnamed surficial aquifers; GDU, General Developement Utilities; W/A, water association; SSU, Southern States Utilities; WRWSA, Withlacoochee Regional Water Supply Authority; Ser., service; W/S, water system; Co., county; WCRWSA, West Coast Regional Water Supply Authority; UIF, Utilities Incorporated of Florida; Vil., village; Comm., commission; MHU, Mad Hatter Utilities; PCU, Pasco County Utilities; N/A, not available; WF, wellfield; Ent., enterprises; PCWS, Pinellas County Water System; PCBoCC, Polk County Board of County Commissioners; WFC. West Florida Community; Bch., Beach; Riv., River]

\begin{tabular}{|c|c|c|c|c|c|c|}
\hline \multirow{2}{*}{ Utility/Owner } & \multirow{2}{*}{ County } & \multirow{2}{*}{ Cataloging unit } & \multicolumn{2}{|c|}{ Water source } & \multirow{2}{*}{$\begin{array}{c}1990 \\
\mathrm{Mgal} / \mathrm{d}\end{array}$} & \multirow{2}{*}{$\begin{array}{c}1990 \\
\text { Population } \\
\text { served }\end{array}$} \\
\hline & & & Name & Percent & & \\
\hline SSU: Oak Forest & Citrus & Crystal - Pithlachasotte & FAS & 100 & 0.07 & 318 \\
\hline SSU: Point-O-Woods & Citrus & Crystal - Pithlachasotte & FAS & 100 & 0.06 & 740 \\
\hline SSU: Rolling Green & Citrus & Crystal - Pithlachasotte & FAS & 100 & 0.04 & 306 \\
\hline SSU: Rosemont & Citrus & Crystal - Pithlachasotte & FAS & 100 & 0.01 & 136 \\
\hline SSU: Sugar Mill/Suntaac & Citrus & Crystal - Pithlachasotte & FAS & 100 & 0.54 & 3,668 \\
\hline WRWSA: Meadowcreast & Citrus & Crystal - Pithlachasotte & FAS & 100 & 1.22 & 4,400 \\
\hline Clay Utility Company & Clay & Lower St. Johns River & FAS & 100 & 0.90 & 7,914 \\
\hline Duval Utility Company & Clay & Lower St. Johns River & FAS & 100 & 0.03 & 243 \\
\hline Green Cove Springs, city of & Clay & Lower St. Johns River & FAS & 100 & 0.83 & 4,497 \\
\hline Keystone Heights,city of & Clay & Lower St. Johns River & FAS & 100 & 0.22 & 2,774 \\
\hline Kingsley Ser. Company & Clay & Lower St. Johns River & FAS & 100 & 7.14 & 46,515 \\
\hline Lake Asbury Utilities & Clay & Lower St. Johns River & FAS & 100 & 0.23 & 1,673 \\
\hline Magnolia Springs Utility & Clay & Lower St. Johns River & FAS & 100 & 0.16 & 858 \\
\hline Orange Park, town of & Clay & Lower St. Johns River & FAS & 100 & 1.43 & 9.488 \\
\hline Penny Retirement W/S & Clay & Lower St. Johns River & FAS & 100 & 0.06 & 226 \\
\hline Penny Farms, town of & Clay & Lower St. Johns River & FAS & 100 & 0.04 & 609 \\
\hline Ravines Village/Resort & Clay & Lower St. Johns River & FAS & 100 & 0.07 & 500 \\
\hline Azalea Park S/D & Columbia & Santa Fe River & FAS & 100 & 0.03 & 258 \\
\hline Belaire W/S & Columbia & Santa Fe River & FAS & 100 & 0.03 & 264 \\
\hline Clayton Smith S/D & Columbia & Santa Fe River & FAS & 100 & 0.06 & 486 \\
\hline Gatortown Utilities & Columbia & Santa Fe River & FAS & 100 & 0.05 & 374 \\
\hline Lake City, city of & Columbia & Santa Fe River & FAS & 100 & 2.61 & 12,616 \\
\hline Melton Bishop S/D & Columbia & Santa Fe River & FAS & 100 & 0.13 & 1,188 \\
\hline Woodgate Village W/S & Columbia & Santa Fe River & FAS & 100 & 0.02 & 150 \\
\hline Cross City W/S & Dixie & Econfina - Steinhatchee & FAS & 100 & 0.51 & 3,010 \\
\hline Horseshoe Beach W/A & Dixie & Econfina - Steinhatchee & FAS & 100 & 0.05 & 375 \\
\hline Shady Oaks Trailer Park & Dixie & Econfina - Steinhatchee & FAS & 100 & 0.01 & 220 \\
\hline Suwannee W/A & Dixie & Econfina - Steinhatchee & FAS & 100 & 0.09 & 950 \\
\hline Atlantic Beach, city of & Duval & Lower St. Johns River & FAS & 100 & 2.65 & 13,747 \\
\hline Baldwin, city of & Duval & St. Marys River & FAS & 100 & 0.21 & 1,450 \\
\hline Beauclerc Utilities & Duval & Lower St. Johns River & FAS & 100 & 0.65 & 6,670 \\
\hline Canal Utilities & Duval & Lower St. Johns River & FAS & 100 & 2.08 & 7,734 \\
\hline Colony MHP & Duval & Lower St. Johns River & FAS & 100 & 0.06 & 962 \\
\hline Commercial Utilities & Duval & Lower St. Johns River & FAS & 100 & 0.11 & 1,200 \\
\hline Duval Utilities & Duval & Lower St. Johns River & FAS & 100 & 0.05 & 252 \\
\hline Harbor View S/D & Duval & Lower St. Johns River & FAS & 100 & 0.19 & 2,100 \\
\hline Jacksonville Beach,city of & Duval & Lower St. Johns River & FAS & 100 & 2.84 & 17,839 \\
\hline Jacksonville, city of & Duval & Lower St. Johns River & FAS & 100 & 70.49 & 441,515 \\
\hline Jacksonville Suburban Ut. & Duval & Lower St. Johns River & FAS & 100 & 9.93 & 78,158 \\
\hline Lamplighter MHP & Duval & Lower St. Johns River & FAS & 100 & 0.15 & 892 \\
\hline Londontown Apartments & Duval & Lower St. Johns River & FAS & 100 & 0.23 & 1,125 \\
\hline Neighborhood Utilities & Duval & Lower St. Johns River & FAS & 100 & 0.04 & 543 \\
\hline Neptune Beach, city of & Duval & Lower St. Johns River & FAS & 100 & 1.21 & 6,816 \\
\hline Normandy Estates W/S & Duval & Lower St. Johns River & FAS & 100 & 0.12 & 500 \\
\hline
\end{tabular}


Appendix 1. Public-supply water use by utility in the Georgia-Florida Coastal Plain study unit, 1990 —Continued This appendix is divided into the following sections: A. Within Florida. B. Within Georgia.

[A. Florida. [Modified from Marella, 1993; Mgal/d, million gallons per day; FAS, Floridan aquifer system; Ut., utility; MHP, mobile home park; S/D, sub division; USA, unnamed surficial aquifers; GDU, General Developement Utilities; W/A, water association; SSU, Southern States Utilities; WRWSA, Withlacoochee Regional Water Supply Authority; Ser., service; W/S, water system; Co., county; WCRWSA, West Coast Regional Water Supply Authority: UIF, Utilities Incorporated of Florida; Vil., village; Comm., commission; MHU, Mad Hatter Utilities; PCU, Pasco County Utilities; N/A, not available; WF, wellfield; Ent., enterprises; PCWS, Pinellas County Water System; PCBoCC, Polk County Board of County Commissioners; WFC, West Florida Community; Bch., Beach; Riv., River]

\begin{tabular}{|c|c|c|c|c|c|c|}
\hline \multirow{2}{*}{ Utility/Owner } & \multirow{2}{*}{ County } & \multirow{2}{*}{ Cataloging unit } & \multicolumn{2}{|c|}{ Water source } & \multirow{2}{*}{$\begin{array}{c}1990 \\
\text { Mgal/d }\end{array}$} & \multirow{2}{*}{$\begin{array}{c}1990 \\
\text { Population } \\
\text { served }\end{array}$} \\
\hline & & & Name & Percent & & \\
\hline Normandy Village Utility & Duval & Lower St. Johns River & FAS & 100 & 0.44 & 3.266 \\
\hline Oaks of Atlantic Beach & Duval & Lower St. Johns River & FAS & 100 & 0.10 & 825 \\
\hline Ortega Utilities & Duval & Lower St. Johns River & FAS & 100 & 1.02 & 4,423 \\
\hline Regency Utilities & Duval & Lower St. Johns River & FAS & 100 & 0.80 & 4,900 \\
\hline Shadowrock Utilities & Duval & Lower St. Johns River & FAS & 100 & 0.24 & 1,250 \\
\hline Southern Gulf Utilities & Duval & Lower St. Johns River & FAS & 100 & 0.24 & 2,900 \\
\hline SSU - Duval Co. totals & Duval & Lower St. Johns River & FAS & 100 & 1.31 & 11,524 \\
\hline Southside Utilities & Duval & Lower St. Johns River & FAS & 100 & 1.16 & 8.605 \\
\hline Beverly Beach Utility & Flagler & Daytona - St. Augustine & FAS & 100 & 0.03 & 312 \\
\hline Bunnell, city of & Flagler & Lower St. Johns River & FAS & 100 & 0.33 & 1,873 \\
\hline Flagler Beach, city of & Flagler & Daytona - St. Augustine & FAS & 100 & 0.57 & 3,820 \\
\hline Plantation Bay & Flagler & Daytona - St. Augustine & FAS & 100 & 0.05 & 324 \\
\hline Palm Coast Utilities & Flagler & Daytona - St. Augustine & USA & 100 & 2.87 & 13,000 \\
\hline Greensboro, town of & Gadsden & Lower Ochlockonee River & FAS & 100 & 0.07 & 586 \\
\hline Gretna, town of & Gadsden & Lower Ochlockonee River & FAS & 100 & 0.21 & 1,981 \\
\hline Havana, city of & Gadsden & Lower Ochlockonee River & FAS & 100 & 0.61 & 3,994 \\
\hline Joyland S/D & Gadsden & Lower Ochlockonee River & FAS & 100 & 0.01 & 133 \\
\hline Rentz's MHP & Gadsden & Lower Ochlockonee River & FAS & 100 & 0.03 & 144 \\
\hline Quincy, city of & Gadsden & Lower Ochlockonee River & Quincy Creek/FAS & $97 / 3$ & 1.33 & 8.420 \\
\hline Talquin Electric & Gadsden & Lower Ochlockonee River & FAS & 100 & 0.56 & 6,495 \\
\hline Trenton, town of & Gilchrist & Lower Suwannee River & FAS & 100 & 0.27 & 1,656 \\
\hline Jasper, city of & Hamilton & Upper Suwannee River & FAS & 100 & 0.69 & 3,372 \\
\hline Jennings, town of & Hamilton & Alapaha River & FAS & 100 & 0.11 & 781 \\
\hline White Springs, city of & Hamilton & Upper Suwannee River & FAS & 100 & 0.17 & 948 \\
\hline Brooksville, city of & Hernando & Crystal - Pithlachasotte & FAS & 100 & 1.58 & 10,852 \\
\hline Hernando Co.: Brookridge & Hernando & Crystal - Pithlachasotte & FAS & 100 & 3.79 & 23.098 \\
\hline Hernando Co.: Cedar Lane & Hernando & Withlacoochee River & FAS & 100 & 0.03 & 293 \\
\hline Hernando Co.: Lakeside & Hernando & Withlacoochee River & FAS & 100 & 0.03 & 322 \\
\hline Hernando Co.: Number 1 & Hernando & Crystal - Pithlachasotte & FAS & 100 & 0.45 & 3,292 \\
\hline Hernando Co.: Number 2 & Hernando & Crystal - Pithlachasotte & FAS & 100 & 0.07 & 466 \\
\hline Hernando Co.: Number 3 & Hernando & Withlacoochee River & FAS & 100 & 0.14 & 1,199 \\
\hline Hernando Co.: Number 5 & Hernando & Withlacoochee River & FAS & 100 & 0.02 & 156 \\
\hline Hernando Co.: Number 6 & Hernando & Withlacoochee River & FAS & 100 & 0.01 & 201 \\
\hline Hernando Co.: Springwood & Hernando & Crystal - Pithlachasotte & FAS & 100 & 0.07 & 254 \\
\hline Spring Hill Utilities & Hernando & Crystal - Pithlachasotte & FAS & 100 & 8.78 & 52,187 \\
\hline Allied/USA Utilities & Hillsborough & Tampa Bay & FAS & 100 & 0.25 & 2,239 \\
\hline Charles Springer & Hillsborough & Tampa Bay & FAS & 100 & 0.11 & 1,004 \\
\hline Country Meadows Estates & Hillsborough & Tampa Bay & FAS & 100 & 0.35 & 1,400 \\
\hline Eagles Utility Company & Hillsborough & Tampa Bay & FAS & 100 & 0.05 & 109 \\
\hline Featherock MHP & Hillsborough & Tampa Bay & FAS & 100 & 0.11 & 771 \\
\hline Florida Cities Water & Hillsborough & Tampa Bay & FAS & 100 & 0.80 & 2,796 \\
\hline Hillsborough County Ut. & Hillsborough & Alafia River & FAS & 100 & 0.16 & 420 \\
\hline Lake Highlands/Moorings & Hillsborough & Tampa Bay & FAS & 100 & 0.03 & 180 \\
\hline Little Manatee Isle MHP & Hillsborough & Little Manatee River & FAS & 100 & 0.01 & 75 \\
\hline
\end{tabular}


Appendix 1. Public-supply water use by utility in the Georgia-Florida Coastal Plain study unit, 1990 - Continued This appendix is divided into the following sections: A. Within Florida. B. Within Georgia.

[A. Florida. [Modified from Marella, 1993; Mgal/d, million gallons per day; FAS, Floridan aquifer system; Ut., utility; MHP, mobile home park; S/D, sub division; USA, unnamed surficial aquifers; GDU, General Developement Utilities; W/A, water association; SSU, Southern States Utilities; WRWSA, Withlacoochee Regional Water Supply Authority; Ser., service; W/S, water system; Co., county; WCRWSA, West Coast Regional Water Supply Authority; UIF, Utilities Incorporated of Florida; Vil., village; Comm., commission; MHU, Mad Hatter Utilities; PCU, Pasco County Utilities; N/A, not available; WF, wellfield; Ent., enterprises; PCWS, Pinellas County Water System; PCBoCC, Polk County Board of County Commissioners; WFC, West Florida Community; Bch., Beach; Riv., River]

\begin{tabular}{|c|c|c|c|c|c|c|}
\hline \multirow{2}{*}{ Utility/Owner } & \multirow{2}{*}{ County } & \multirow{2}{*}{ Cataloging unit } & \multicolumn{2}{|c|}{ Water source } & \multirow{2}{*}{$\begin{array}{c}1990 \\
\text { Mgal/d }\end{array}$} & \multirow{2}{*}{$\begin{array}{c}1990 \\
\text { Population } \\
\text { served }\end{array}$} \\
\hline & & & Name & Percent & & \\
\hline Paradise Village & Hillsborough & Tampa Bay & FAS & 100 & 0.12 & 1,242 \\
\hline Pebble Creek Ser. Area & Hillsborough & Alifia River & FAS & 100 & 0.32 & 2,067 \\
\hline Plant City, city of & Hillsborough & Hillsborough River & FAS & 100 & 4.87 & 23,177 \\
\hline Scarecrow Ut.: San Remo & Hillsborough & Tampa Bay & FAS & 100 & 0.02 & 138 \\
\hline SSU: Hershel Heights & Hillsborough & Hillsborough River & FAS & 100 & 0.10 & 843 \\
\hline SSU: Seaboard & Hillsborough & Alifia River & FAS & 100 & 0.89 & 7,111 \\
\hline SSU: Valrico Hills & Hillsborough & Hillsborough River & FAS & 100 & 0.10 & 894 \\
\hline Tampa, city of & Hillsborough & Hillsborough River & Hillsborough River/FAS & $93 / 7$ & 81.44 & 468,458 \\
\hline Temple Terrace, city of & Hillsborough & Hillsborough River & FAS & 100 & 3.36 & 26,513 \\
\hline Village Green MHP & Hillsborough & Tampa Bay & FAS & 100 & 0.02 & 100 \\
\hline WCRWSA: Northwest Hills. & Hillsborough & Hillsborough River & FAS & 100 & 13.08 & 119,000 \\
\hline WCRWSA: South-Central & Hillsborough & Little Manatee River & FAS & 100 & 18.92 & 171,700 \\
\hline Wilder/Hawaiian Isles & Hillsborough & Tampa Bay & FAS & 100 & 0.06 & 789 \\
\hline Wilder/Southern Aire MHP & Hillsborough & Tampa Bay & FAS & 100 & 0.02 & 315 \\
\hline Aspen-Whispering Palms & Indian River & Vero Beach Coastal & FAS & 100 & 0.08 & 1,334 \\
\hline GDU-Sebastian Highlands & Indian River & Vero Beach Coastal & FAS & 100 & 0.31 & 2,502 \\
\hline Heritage Village W/S & Indian River & Vero Beach Coastal & FAS & 100 & 0.06 & 654 \\
\hline Heron Cay & Indian River & Vero Beach Coastal & FAS & 100 & 0.04 & 588 \\
\hline Indian River County Ut. & Indian River & Vero Beach Coastal & FAS & 100 & 2.36 & 19,465 \\
\hline Lakewood Village W/S & Indian River & Vero Beach Coastal & FAS & 100 & 0.07 & 1,095 \\
\hline Marsh Island Utilities & Indian River & Vero Beach Coastal & FAS & 100 & 0.02 & 382 \\
\hline North Beach Utilities & Indian River & Vero Beach Coastal & FAS & 100 & 0.32 & 1,890 \\
\hline Pelican Pointe Utilities & Indian River & Vero Beach Coastal & FAS & 100 & 0.03 & 325 \\
\hline Vero Beach, city of & Indian River & Vero Beach Coastal & USA and FAS & $84 / 16$ & 9.79 & 24.067 \\
\hline Village Green W/S & Indian River & Vero Beach Coastal & FAS & 100 & 0.09 & 1,432 \\
\hline Monticello, city of & Jefferson & Apalachee Bay - St. Markss & FAS & 100 & 0.72 & 4,620 \\
\hline Mayo, city of & Lafayette & Econfina - Steinhatchee & FAS & 100 & 0.18 & 1,140 \\
\hline Astor Park W/A & Lake & Upper St. Johns River & FAS & 100 & 0.27 & 3,000 \\
\hline Brittany Estates & Lake & Oklawaha River & FAS & 100 & 0.07 & 315 \\
\hline Clermont, city of & Lake & Oklawaha River & FAS & 100 & 1.52 & 6,910 \\
\hline Deanza W/S & Lake & Oklawaha River & FAS & 100 & 0.68 & 2,698 \\
\hline Eustis, city of & Lake & Oklawaha River & FAS & 100 & 2.82 & 18,105 \\
\hline Fruitland Park, city of & Lake & Oklawaha River & FAS & 100 & 0.42 & 2,754 \\
\hline Groveland, city of & Lake & Oklawaha River & FAS & 100 & 0.29 & 2,300 \\
\hline Hawthorne S/D & Lake & Oklawaha River & FAS & 100 & 0.49 & 2,885 \\
\hline Howey-In-The-Hills W/S & Lake & Oklawaha River & FAS & 100 & 0.24 & 724 \\
\hline Lakeview Terrace Center & Lake & Oklawaha River & FAS & 100 & 0.04 & 300 \\
\hline Leesburg, city of & Lake & Oklawaha River & FAS & 100 & 4.17 & 19,897 \\
\hline Mascotte, town of & Lake & Oklawaha River & FAS & 100 & 0.20 & 1,764 \\
\hline Minneola, city of & Lake & Oklawaha River & FAS & 100 & 0.22 & 1,528 \\
\hline Molakai Park W/S & Lake & Oklawaha River & FAS & 100 & 0.04 & 550 \\
\hline Montverde, town of & Lake & Oklawaha River & FAS & 100 & 0.12 & 667 \\
\hline Mt. Dora, city of & Lake & Oklawaha River & FAS & 100 & 2.82 & 12,347 \\
\hline Orange Blossom Gardens & Lake & Oklawaha River & FAS & 100 & 2.52 & 9,714 \\
\hline
\end{tabular}


Appendix 1. Public-supply water use by utility in the Georgia-Florida Coastal Plain study unit, 1990 —Continued This appendix is divided into the following sections: A. Within Florida. B. Within Georgia.

[A. Florida. [Modified from Marella, 1993; Mgal/d, million gallons per day; FAS, Floridan aquifer system; Ut., utility; MHP, mobile home park; S/D, sub division; USA, unnamed surficial aquifers; GDU, General Developement Utilities; W/A, water association; SSU, Southern States Utilities; WRWSA, Withlacoochee Regional Water Supply Authority; Ser., service; W/S, water system; Co., county; WCRWSA, West Coast Regional Water Supply Authority; UIF, Utilities Incorporated of Florida; Vil., village; Comm., commission; MHU, Mad Hatter Utilities; PCU, Pasco County Utilities; N/A. not available; WF, wellfield; Ent., enterprises; PCWS, Pinellas County Water System: PCBoCC, Polk County Board of County Commissioners; WFC, West Florida Community; Bch., Beach; Riv., River]

\begin{tabular}{|c|c|c|c|c|c|c|}
\hline \multirow{2}{*}{ Utility/Owner } & \multirow{2}{*}{ County } & \multirow{2}{*}{ Cataloging unit } & \multicolumn{2}{|c|}{ Water source } & \multirow{2}{*}{$\begin{array}{c}1990 \\
\mathrm{Mgal} / \mathrm{d}\end{array}$} & \multirow{2}{*}{$\begin{array}{c}1990 \\
\text { Population } \\
\text { served }\end{array}$} \\
\hline & & & Name & Percent & & \\
\hline Silver Lake Estates Ut. & Lake & Oklawaha River & FAS & 100 & 0.83 & 2,020 \\
\hline South Umatilla W/A & Lake & Oklawaha River & FAS & 100 & 0.06 & 375 \\
\hline SSU - Lake Co. totals & Lake & Oklawaha River & FAS & 100 & 0.22 & 2,646 \\
\hline Sunlake Estates & Lake & Oklawaha River & FAS & 100 & 0.31 & 576 \\
\hline Tavares, city of & Lake & Oklawaha River & FAS & 100 & 1.40 & 7,383 \\
\hline Umatilla, city of & Lake & Oklawaha River & FAS & 100 & 0.49 & 2,559 \\
\hline UIF - Lake Co. totals & Lake & Oklawaha River & FAS & 100 & 0.16 & 558 \\
\hline Water Oak Estates & Lake & Oklawaha River & FAS & 100 & 0.27 & 1,210 \\
\hline Deer Tree Hills S/D & Leon & Apalachee Bay - St.Marks & FAS & 100 & 0.02 & 194 \\
\hline Greenwood MHP & Leon & Apalachee Bay - St.Marks & FAS & 100 & 0.03 & 255 \\
\hline Lake Bradford MHP & Leon & Apalachee Bay - St.Marks & FAS & 100 & 0.03 & 175 \\
\hline Rowe Drilling and Ut. & Leon & Apalachee Bay - St.Marks & FAS & 100 & 0.17 & 1,430 \\
\hline Spencers S/D & Leon & Apalachee Bay - St.Marks & FAS & 100 & 0.02 & 141 \\
\hline Southern Bell MHP & Leon & Apalachee Bay - St.Marks & FAS & 100 & 0.03 & 200 \\
\hline Tallahassee, city of & Leon & Apalachee Bay - St.Marks & FAS & 100 & 22.41 & 138,989 \\
\hline Talquin Electric & Leon & Lower Ochlockonee River & FAS & 100 & 2.31 & 15,197 \\
\hline Bronson, town of & Levy & Waccasassa River & FAS & 100 & 0.15 & 1.109 \\
\hline Cedar Key, town of & Levy & Waccasassa River & FAS & 100 & 0.17 & 935 \\
\hline Chiefland, town of & Levy & Lower Suwannee River & FAS & 100 & 0.47 & 1,917 \\
\hline Fanning Springs, town of & Levy & Lower Suwannee River & FAS & 100 & 0.06 & 489 \\
\hline Fowlers Bluff W/A & Levy & Waccasassa River & FAS & 100 & 0.02 & 350 \\
\hline Hide-A-Way MHP & Levy & Waccasassa River & FAS & 100 & 0.03 & 204 \\
\hline Otter Creek, town of & Levy & Waccasassa River & FAS & 100 & 0.01 & 227 \\
\hline Inglis, town of & Levy & Withlacoochee River & FAS & 100 & 0.15 & 1,798 \\
\hline Williston, city of & Levy & Oklawaha River & FAS & 100 & 0.41 & 2,421 \\
\hline Yankeetown, town of & Levy & Waccasassa River & FAS & 100 & 0.11 & 1,023 \\
\hline Hosford/Telogia W/S & Liberty & Lower Ochlockonee River & FAS & 100 & 0.06 & 485 \\
\hline Talquin Electric & Liberty & Lower Ochlockonee River & FAS & 100 & 0.01 & 67 \\
\hline Cherry Lake Utilities & Madison & Withlacoochee River & FAS & 100 & 0.05 & 620 \\
\hline Greenville, city of & Madison & Aucilla River & FAS & 100 & 0.20 & 1,061 \\
\hline Madison, city of & Madison & Aucilla River & FAS & 100 & 1.18 & 4,262 \\
\hline Amaroc/Edison/Foxwood & Marion & Withlacoochee River & FAS & 100 & 0.06 & 586 \\
\hline Belleview, city of & Marion & Withlacoochee River & FAS & 100 & 0.53 & 4,802 \\
\hline CHC II/Saddlebrook MHP & Marion & Oklawaha River & FAS & 100 & 0.17 & 400 \\
\hline Decca Utilities: Oak Run & Marion & Oklawaha River & FAS & 100 & 0.97 & 2,928 \\
\hline Decca Utilities:Pine Run & Marion & Oklawaha River & FAS & 100 & 0.62 & 2,023 \\
\hline Dunnellon, city of & Marion & Oklawaha River & FAS & 100 & 0.28 & 1,735 \\
\hline GDU-Silver Springs Shore & Marion & Oklawaha River & FAS & 100 & 1.12 & 10,579 \\
\hline Living Development Co. & Marion & Oklawaha River & FAS & 100 & 0.02 & 38 \\
\hline Maco Development Co. & Marion & Oklawaha River & FAS & 100 & 0.11 & 530 \\
\hline Marion Utilities & Marion & Oklawaha River & FAS & 100 & 0.46 & 4,231 \\
\hline McIntosh, city of & Marion & Oklawaha River & FAS & 100 & 0.09 & 411 \\
\hline Ocala East Utilities & Marion & Oklawaha River & FAS & 100 & 0.13 & 593 \\
\hline Ocala Housing Corporation & Marion & Oklawaha River & FAS & 100 & 0.09 & 140 \\
\hline
\end{tabular}


Appendix 1. Public-supply water use by utility in the Georgia-Florida Coastal Plain study unit, 1990 - Continued This appendix is divided into the following sections: A. Within Florida. B. Within Georgia.

[A. Florida. [Modified from Marella, 1993; Mgal/d, million gallons per day; FAS, Floridan aquifer system; Ut., utility; MHP, mobile home park; S/D, sub division; USA, unnamed surficial aquifers: GDU, General Developement Utilities; W/A, water association; SSU, Southern States Utilities; WRWSA, Withlacoochee Regional Water Supply Authority; Ser., service; W/S, water system; Co., county; WCRWSA, West Coast Regional Water Supply Authority; UIF, Utilities Incorporated of Florida; Vil., village; Comm., commission; MHU, Mad Hatter Utilities; PCU, Pasco County Utilities; N/A, not available; WF, wellfield; Ent., enterprises; PCWS, Pinellas County Water System; PCBoCC, Polk County Board of County Commissioners; WFC, West Florida Community; Bch., Beach; Riv., River]

\begin{tabular}{|c|c|c|c|c|c|c|}
\hline \multirow{2}{*}{ Utility/Owner } & \multirow{2}{*}{ County } & \multirow{2}{*}{ Cataloging unit } & \multicolumn{2}{|c|}{ Water source } & \multirow{2}{*}{$\begin{array}{c}1990 \\
\text { Mgal/d }\end{array}$} & \multirow{2}{*}{$\begin{array}{c}1990 \\
\text { Population } \\
\text { served }\end{array}$} \\
\hline & & & Name & Percent & & \\
\hline Ocala Oaks Utilities & Marion & Oklawaha River & FAS & 100 & 0.26 & 1,981 \\
\hline Ocala, city of & Marion & Oklawaha River & FAS & 100 & 8.24 & 42,045 \\
\hline Quail Hollow & Marion & Oklawaha River & FAS & 100 & 0.02 & 163 \\
\hline Rainbow Springs Utility & Marion & Oklawaha River & FAS & 100 & 0.56 & 383 \\
\hline SSU: Citrus Park & Marion & Oklawaha River & FAS & 100 & 0.10 & 780 \\
\hline SSU: Marion Oaks & Marion & Oklawaha River & FAS & 100 & 0.77 & 5,195 \\
\hline SSU: Salt Springs Vil. & Marion & Upper St. Johns River & FAS & 100 & 0.06 & 459 \\
\hline Sunshine Utilities & Marion & Oklawaha River & FAS & 100 & 0.43 & 3,711 \\
\hline Sweetwater Oaks & Marion & Oklawaha River & FAS & 100 & 0.01 & 15 \\
\hline Top of the World W/S & Marion & Oklawaha River & FAS & 100 & 0.87 & 2,772 \\
\hline Tradewinds Utilities & Marion & Oklawaha River & FAS & 100 & 0.09 & 850 \\
\hline UIF: Golden Hills & Marion & Oklawaha River & FAS & 100 & 0.15 & 900 \\
\hline Venture Associates & Marion & Oklawaha River & FAS & 100 & 0.22 & 1.154 \\
\hline Windstream Utilities & Marion & Oklawaha River & FAS & 100 & 0.01 & 162 \\
\hline Woods and Lakes S/D & Marion & Oklawaha River & FAS & 100 & 0.03 & 283 \\
\hline Callahan. town of & Nassau & Nassau River & FAS & 100 & 0.15 & 1,295 \\
\hline Eastwood Oaks W/S & Nassau & Nassau River & FAS & 100 & 0.03 & 365 \\
\hline Florida Public Ut. & Nassau & St. Marys River & FAS & 100 & 2.65 & 12,738 \\
\hline Hillard, town of & Nassau & St. Marys River & FAS & 100 & 0.25 & 2,082 \\
\hline Marsh Cove W/S & Nassau & St. Marys River & FAS & 100 & 0.04 & 268 \\
\hline SSU: Amelia Island & Nassau & Nassau River & FAS & 100 & 0.73 & 5,266 \\
\hline Apopka, city of & Orange & Upper St. Johns River & FAS & 100 & 5.29 & 23,250 \\
\hline Eatonville, town of & Orange & Upper St. Johns River & FAS & 100 & 0.69 & 2,170 \\
\hline Econ Ut./Wedgefield S/D & Orange & Upper St. Johns River & FAS & 100 & 0.16 & 1,229 \\
\hline Maitland, city of & Orange & Upper St. Johns River & FAS & 100 & 3.16 & 9,110 \\
\hline Oakland, town of & Orange & Oklawaha River & FAS & 100 & 0.11 & 700 \\
\hline Ocoee, city of & Orange & Oklawaha River & FAS & 100 & 2.69 & 12,778 \\
\hline Orange County Utilities & Orange & Upper St. Johns River & FAS & 100 & 27.76 & 96,089 \\
\hline Orlando Utilities Comm. & Orange & Upper St. Johns River & FAS & 100 & 79.28 & 399,720 \\
\hline Rock Springs MHP & Orange & Upper St. Johns River & FAS & 100 & 0.24 & 1,240 \\
\hline SSU - Orange Co. totals & Orange & Upper St. Johns River & FAS & 100 & 1.00 & 6,631 \\
\hline Starlight Ranch MHP & Orange & Upper St. Johns River & FAS & 100 & 0.18 & 1,560 \\
\hline Tangerine, town of & Orange & Oklawaha River & FAS & 100 & 0.14 & 428 \\
\hline Taft, city of & Orange & Kissimmee River & FAS & 100 & 0.28 & 2,145 \\
\hline UIF - Orange Co. totals & Orange & Upper St. Johns River & FAS & 100 & 0.10 & 1,103 \\
\hline Winter Garden, city of & Orange & Oklawaha River & FAS & 100 & 1.78 & 12,140 \\
\hline Winter Park, city of & Orange & Upper St. Johns River & FAS & 100 & 13.62 & 80,214 \\
\hline Zellwood Station Ut. & Orange & Oklawaha River & FAS & 100 & 0.96 & 2,332 \\
\hline Zellwood W/A & Orange & Oklawaha River & FAS & 100 & 0.33 & 900 \\
\hline Harbour Oaks Utilities & Osceola & Kissimmee River & FAS & 100 & 0.12 & 831 \\
\hline Kissimmee, city of & Osceola & Kissimmee River & FAS & 100 & 7.33 & 31,878 \\
\hline Kissimmee Good Samaratin & Osceola & Kissimmee River & FAS & 100 & 0.22 & 1,924 \\
\hline Majestic Oaks & Osceola & Kissimmee River & FAS & 100 & 0.02 & 187 \\
\hline Morningside Utilities & Osceola & Kissimmee River & FAS & 100 & 0.03 & 250 \\
\hline
\end{tabular}


Appendix 1. Public-supply water use by utility in the Georgia-Florida Coastal Plain study unit, 1990 -Continued This appendix is divided into the following sections: A. Within Florida. B. Within Georgia.

[A. Florida. [Modified from Marella, 1993; Mgal/d, million gallons per day; FAS, Floridan aquifer system; Ut., utility; MHP, mobile home park; S/D, sub division; USA, unnamed surficial aquifers; GDU, General Developement Utilities; W/A. water association; SSU, Southern States Utilities; WRWSA, Withlacoochee Regional Water Supply Authority; Ser., service; W/S, water system; Co., county; WCRWSA, West Coast Regional Water Supply Authority; UIF, Utilities Incorporated of Florida; Vil., village; Comm., commission; MHU, Mad Hatter Utilities: PCU, Pasco County Utilities; N/A, not available; WF, wellfield; Ent., enterprises: PCWS, Pinellas County Water System; PCBoCC, Polk County Board of County Commissioners; WFC, West Florida Community; Bch., Beach; Riv., River]

\begin{tabular}{|c|c|c|c|c|c|c|}
\hline \multirow{2}{*}{ Utility/Owner } & \multirow{2}{*}{ County } & \multirow{2}{*}{ Cataloging unit } & \multicolumn{2}{|c|}{ Water source } & \multirow{2}{*}{$\begin{array}{c}1990 \\
\text { Mgal/d }\end{array}$} & \multirow{2}{*}{$\begin{array}{c}1990 \\
\text { Population } \\
\text { served }\end{array}$} \\
\hline & & & Name & Percent & & \\
\hline Oak Forrest S/D & Osceola & Kissimmee River & FAS & 100 & 0.01 & 100 \\
\hline Poinciana Utilities & Osceola & Kissimmee River & FAS & 100 & 0.76 & 5,663 \\
\hline Orange/Osceola Utilities & Osceola & Kissimmee River & FAS & 100 & 1.39 & 17,985 \\
\hline St. Cloud, city of & Osceola & Kissimmee River & FAS & 100 & 1.89 & 17,696 \\
\hline SSU - Osceola Co totals & Osceola & Kissimmee River & FAS & 100 & 0.31 & 3,111 \\
\hline Aloha Utilities & Pasco & Crystal - Pithlachasotte & FAS & 100 & 2.12 & 18,755 \\
\hline Barrington Hills & Pasco & Withlacoochee River & FAS & 100 & 0.03 & 100 \\
\hline Betmar Utilities & Pasco & Hillsborough River & FAS & 100 & 0.13 & 2.577 \\
\hline Crystal Springs W/S & Pasco & Hillsborough River & FAS & 100 & 0.05 & 592 \\
\hline Dade City, city of & Pasco & Withlacoochee River & FAS & 100 & 1.32 & 9,014 \\
\hline Dixie Grove Estates & Pasco & Crystal - Pithlachasotte & FAS & 100 & 0.11 & 723 \\
\hline Floralino Properties & Pasco & Crystal - Pithlachasotte & FAS & 100 & 0.16 & 2,000 \\
\hline Forest Hills Utilities & Pasco & Crystal - Pithlachasotte & FAS & 100 & 0.46 & 6,100 \\
\hline Forrest Lake Estates & Pasco & Hillsborough River & FAS & 100 & 0.03 & 904 \\
\hline Hacienda Village & Pasco & Crystal - Pithlachasotte & FAS & 100 & 0.06 & 556 \\
\hline Holiday Utility & Pasco & Crystal - Pithlachasotte & FAS & 100 & 0.05 & 570 \\
\hline Hudson Water Works & Pasco & Crystal - Pithlachasotte & FAS & 100 & 0.60 & 4,324 \\
\hline Jasmine Lakes Ser. Area & Pasco & Crystal - Pithlachasotte & FAS & 100 & 0.35 & 3,693 \\
\hline L.W.V. Ut. Corporation & Pasco & Crystal - Pithlachasotte & FAS & 100 & 0.04 & 814 \\
\hline Lindrick Ser. Corporation & Pasco & Crystal - Pithlachasotte & FAS & 100 & 0.83 & 6,884 \\
\hline Magnolia Valley W/S & Pasco & Crystal - Pithlachasotte & FAS & 100 & 0.33 & 3.578 \\
\hline MHU: Carpenters Run & Pasco & Hillsborough River & FAS & 100 & 0.14 & 623 \\
\hline MHU: Foxwood/C. Cove & Pasco & Hillsborough River & FAS & 100 & 0.15 & 899 \\
\hline MHU: Turtle Lakes & Pasco & Hillsborough River & FAS & 100 & 0.26 & 791 \\
\hline New Port Richey, city of & Pasco & Crystal - Pithlachasotte & FAS & 100 & 2.67 & 18,201 \\
\hline Orangewood Lakes MHP & Pasco & Crystal - Pithlachasotte & FAS & 100 & 0.12 & 850 \\
\hline Pasco Utilities & Pasco & Hillsborough River & FAS & 100 & 0.09 & 1,173 \\
\hline PCU: Hickory Hill & Pasco & Withlacoochee River & FAS & 100 & 0.05 & 350 \\
\hline PCU: Hillcrest/Lacoochee & Pasco & Withlacoochee River & FAS & 100 & 0.12 & 380 \\
\hline PCU: Joyland & Pasco & Withlacoochee River & FAS & 100 & 0.02 & 80 \\
\hline PCU: New River Acres & Pasco & Hillsborough River & FAS & 100 & 0.38 & 1,290 \\
\hline PCU: Pasadena & Pasco & Withlacoochee River & FAS & 100 & 0.01 & 98 \\
\hline PCU: Sunburst Hills & Pasco & Withlacoochee River & FAS & 100 & 0.03 & 250 \\
\hline PCU: West Pasco System & Pasco & Crystal - Pithlachasotte & FAS & 100 & 11.15 & 98.300 \\
\hline PCU: Z-Groves & Pasco & Hillsborough River & FAS & 100 & 0.03 & 317 \\
\hline Port Richey, city of & Pasco & Crystal - Pithlachasotte & FAS & 100 & 0.87 & 8,137 \\
\hline Shamerock Heights Ut. & Pasco & Crystal - Pithlachasotte & FAS & 100 & 0.04 & 452 \\
\hline San Antonio, city of & Pasco & Hillsborough River & FAS & 100 & 0.15 & 760 \\
\hline SSU: Palm Terrace & Pasco & Hillsborough River & FAS & 100 & 0.20 & 2,978 \\
\hline SSU: Zephyrhills MHP & Pasco & Hillsborough River & FAS & 100 & 0.06 & 1.367 \\
\hline T.V. Home Owners Assoc. & Pasco & Hillsborough River & FAS & 100 & 0.04 & 479 \\
\hline Travelers Rest MHP & Pasco & Hillsborough River & FAS & 100 & 0.05 & 501 \\
\hline UIF: Orangewood & Pasco & Crystal - Pithlachasotte & FAS & 100 & 0.12 & 1,320 \\
\hline UIF: Paradise Point & Pasco & Crystal - Pithlachasotte & FAS & 100 & 0.17 & 850 \\
\hline
\end{tabular}


Appendix 1. Public-supply water use by utility in the Georgia-Florida Coastal Plain study unit, 1990 —Continued This appendix is divided into the following sections: A. Within Florida. B. Within Georgia.

[A. Florida. [Modified from Marella, 1993; Mgal/d, million gallons per day; FAS, Floridan aquifer system; Ut., utility; MHP, mobile home park; S/D, sub division; USA, unnamed surficial aquifers; GDU, General Developement Utilities; W/A, water association; SSU, Southern States Utilities; WRWSA, Withlacoochee Regional Water Supply Authority; Ser., service; W/S, water system: Co., county; WCRWSA, West Coast Regional Water Supply Authority; UIF, Utilities Incorporated of Florida; Vil., village; Comm., commission; MHU, Mad Hatter Utilities; PCU, Pasco County Utilities; N/A, not available; WF, wellfield; Ent., enterprises; PCWS, Pinellas County Water System: PCBoCC, Polk County Board of County Commissioners; WFC, West Florida Community; Bch., Beach; Riv., River]

\begin{tabular}{|c|c|c|c|c|c|c|}
\hline \multirow{2}{*}{ Utility/Owner } & \multirow{2}{*}{ County } & \multirow{2}{*}{ Cataloging unit } & \multicolumn{2}{|c|}{ Water source } & \multirow{2}{*}{$\begin{array}{c}1990 \\
\text { Mgal/d }\end{array}$} & \multirow{2}{*}{$\begin{array}{c}1990 \\
\text { Population } \\
\text { served }\end{array}$} \\
\hline & & & Name & Percent & & \\
\hline Virginia City Inc. & Pasco & Crystal - Pithlachasotte & FAS & 100 & 0.07 & 660 \\
\hline WCRWSA & Pasco & Crystal - Pithlachasotte & FAS & 100 & 0.68 & $\mathrm{~N} / \mathrm{A}$ \\
\hline Wray Ent.: Bartelt & Pasco & Crystal - Pithlachasotte & FAS & 100 & 0.15 & 2,755 \\
\hline Wray Ent.: Crestridge & Pasco & Crystal - Pithlachasotte & FAS & 100 & 0.11 & 1,385 \\
\hline Wray Ent.: Holiday Gardens & Pasco & Crystal - Pithlachasotte & FAS & 100 & 0.10 & 922 \\
\hline Zephyrhills. city of & Pasco & Hillsborough River & FAS & 100 & 1.46 & 9,042 \\
\hline Belleair, town of & Pinellas & Crystal - Pithlachasotte & FAS & 100 & 1.16 & 5,734 \\
\hline Clearwater, city of & Pinellas & Tampa Bay & Purchased and FAS & $80 / 20$ & 15.88 & 118.133 \\
\hline Dunedin, city of & Pinellas & Tampa Bay & FAS and Purchased & $99 / 1$ & 4.77 & 36,465 \\
\hline Oldsmar & Pinellas & Tampa Bay & Purchased & 100 & 1.11 & 8,334 \\
\hline PCWS & Pinellas & Tampa Bay & Purchased and FAS & 100 & 50.58 & 319,269 \\
\hline Pinellas Park & Pinellas & Tampa Bay & Purchased & 100 & 5.14 & 54,431 \\
\hline Safety Harbor & Pinellas & Tampa Bay & Purchased & 100 & 2.06 & 13,765 \\
\hline St. Petersburg, city of & Pinellas & Tampa Bay & FAS & 100 & 34.35 & 306,366 \\
\hline Tarpon Springs, city of & Pinellas & Crystal - Pithlachasotte & Purchased and FAS & $86 / 14$ & 3.15 & 23,981 \\
\hline Breeze Hill MHP & Polk & Kissimmee River & FAS & 100 & 0.06 & 400 \\
\hline Indian Lake Estates & Polk & Kissimmee River & FAS & 100 & 0.07 & 450 \\
\hline Lake Wales Utilities & Polk & Kissimmee River & FAS & 100 & 0.16 & 2,244 \\
\hline PCBoCC: Sunair & Polk & Kissimmee River & FAS & 100 & 0.22 & 1,520 \\
\hline PCBoCC: Timber Lake Road & Polk & Kissimmee River & FAS & 100 & 0.17 & 1,600 \\
\hline PCBoCC: Walk-in Water & Polk & Kissimmee River & FAS & 100 & 0.04 & 666 \\
\hline Poinciana Village & Polk & Kissimmee River & FAS & 100 & 0.68 & 4,589 \\
\hline Rosalie Oaks & Polk & Kissimmee River & FAS & 100 & 0.01 & 190 \\
\hline Emerald Acres & Polk & Oklawaha River & FAS & 100 & 0.01 & 80 \\
\hline PCBoCC: Polo/Davenport & Polk & Oklawaha River & FAS & 100 & 0.05 & 465 \\
\hline Alturas Water Works & Polk & Peace River & FAS & 100 & 0.02 & 137 \\
\hline Bartow, city of & Polk & Peace River & FAS & 100 & 2.66 & 16,260 \\
\hline Bartow, city of; Airbase & Polk & Peace River & FAS & 100 & 0.57 & 2,287 \\
\hline Carefree RV Country Club & Polk & Peace River & FAS & 100 & 0.21 & 660 \\
\hline CHC VII/Swiss Golf & Polk & Peace River & FAS & 100 & 0.67 & 1,550 \\
\hline Crooked Lake Water & Polk & Peace River & FAS & 100 & 0.20 & 1,657 \\
\hline Cypress Lakes Venture & Polk & Peace River & FAS & 100 & 0.19 & 33 \\
\hline Davenport, city of & Polk & Kissimmee River & FAS & 100 & 0.50 & 2,182 \\
\hline Dundee, town of & Polk & Peace River & FAS & 100 & 0.58 & 2.667 \\
\hline Eagle Lake, city of & Polk & Peace River & FAS & 100 & 0.29 & 2,401 \\
\hline Fort Meade, city of & Polk & Peace River & FAS & 100 & 0.98 & 5,800 \\
\hline Frostproof, city of & Polk & Kissimmee River & FAS & 100 & 1.52 & 3,266 \\
\hline Garden Grove W/S & Polk & Peace River & FAS & 100 & 3.30 & 20,598 \\
\hline Garden Grove/Kinsmen & Polk & Peace River & FAS & 100 & 0.02 & 410 \\
\hline Garden Grove/Towerwood & Polk & Peace River & FAS & 100 & 0.10 & 329 \\
\hline Grenelefe Corporation & Polk & Peace River & FAS & 100 & 3.05 & 3,820 \\
\hline Haines City, city of & Polk & Peace River & FAS & 100 & 2.27 & 11,340 \\
\hline Lake Alfred, city of & Polk & Peace River & FAS & 100 & 0.59 & 3,641 \\
\hline Lake Hamilton, town of & Polk & Peace River & FAS & 100 & 0.32 & 1,958 \\
\hline
\end{tabular}


Appendix 1. Public-supply water use by utility in the Georgia-Florida Coastal Plain study unit, 1990 - Continued This appendix is divided into the following sections: A. Within Florida. B. Within Georgia.

[A. Florida. [Modified from Marella, 1993; Mgal/d, million gallons per day; FAS, Floridan aquifer system; Ut., utility; MHP, mobile home park; S/D, sub division; USA, unnamed surficial aquifers; GDU, General Developement Utilities; W/A, water association; SSU, Southern States Utilities; WRWSA, Withlacoochee Regional Water Supply Authority; Ser., service; W/S, water system; Co., county; WCRWSA, West Coast Regional Water Supply Authority; UIF, Utilities Incorporated of Florida; Vil., village; Comm., commission; MHU, Mad Hatter Utilities; PCU, Pasco County Utilities; N/A, not available; WF, wellfield; Ent., enterprises; PCWS, Pinellas County Water System; PCBoCC, Polk County Board of County Commissioners; WFC, West Florida Community; Bch., Beach; Riv., River]

\begin{tabular}{|c|c|c|c|c|c|c|}
\hline \multirow{2}{*}{ Utility/Owner } & \multirow{2}{*}{ County } & \multirow{2}{*}{ Cataloging unit } & \multicolumn{2}{|c|}{ Water source } & \multirow{2}{*}{$\begin{array}{c}1990 \\
\text { Mgal/d }\end{array}$} & \multirow{2}{*}{$\begin{array}{c}1990 \\
\text { Population } \\
\text { served }\end{array}$} \\
\hline & & & Name & Percent & & \\
\hline Lake Region MHP & Polk & Peace River & FAS & 100 & 0.21 & 701 \\
\hline Lake Wales, city of & Polk & Peace River & FAS & 100 & 3.97 & 12,696 \\
\hline Lakeland, city of & Polk & Peace River & FAS & 100 & 24.37 & 114,988 \\
\hline Mulberry, city of & Polk & Alafia River & FAS & 100 & 0.57 & 3,500 \\
\hline Orchid Springs W/S & Polk & Peace River & FAS & 100 & 0.14 & 976 \\
\hline PCBoCC: Aurburndale & Polk & Peace River & FAS & 100 & 2.28 & 13.118 \\
\hline PCBoCC: Green Acres & Polk & Peace River & FAS & 100 & 0.07 & 546 \\
\hline PCBoCC: Lake Pierce & Polk & Kissimmee River & FAS & 100 & 1.52 & 8,125 \\
\hline PCBoCC: Unnamed number 1 & Polk & Peace River & FAS & 100 & 1.37 & 8,335 \\
\hline PCBoCC: Unnamed number 2 & Polk & Peace River & FAS & 100 & 1.17 & 4,418 \\
\hline PCBoCC: Unnamed number 3 & Polk & Peace River & FAS & 100 & 0.86 & 4,158 \\
\hline PCBoCC: Unnamed number 4 & Polk & Peace River & FAS & 100 & 0.51 & 1,018 \\
\hline PCBoCC: Oak Acres & Polk & Peace River & FAS & 100 & 0.01 & 146 \\
\hline PCBoCC: Rainbow Ridge & Polk & Peace River & FAS & 100 & 0.02 & 184 \\
\hline PCBoCC: Sunray & Polk & Peace River & FAS & 100 & 0.10 & 1,302 \\
\hline PCBoCC: Tanamora & Polk & Peace River & FAS & 100 & 0.01 & 370 \\
\hline PCBoCC: Willowwoods & Polk & Peace River & FAS & 100 & 0.07 & 535 \\
\hline PCBoCC: Wolf Run & Polk & Peace River & FAS & 100 & 0.02 & 208 \\
\hline Plantation Landings LTD. & Polk & Peace River & FAS & 100 & 0.07 & 182 \\
\hline Ridge Utilities & Polk & Peace River & FAS & 100 & 0.10 & 822 \\
\hline Saddlebag Lake W/A & Polk & Peace River & FAS & 100 & 0.11 & 1,051 \\
\hline SSU: Gibsonia & Polk & Peace River & FAS & 100 & 0.05 & 407 \\
\hline SSU: Lake Gibson & Polk & Peace River & FAS & 100 & 0.29 & 1,918 \\
\hline SSU: Orange Hill & Polk & Peace River & FAS & 100 & 0.04 & 592 \\
\hline Sunlake Terrace & Polk & Peace River & FAS & 100 & 0.05 & 342 \\
\hline Swiss Village & Polk & Peace River & FAS & 100 & 0.39 & 1,416 \\
\hline Village of Highland Park & Polk & Peace River & FAS & 100 & 0.16 & 195 \\
\hline WFC: Sweetwater East & Polk & Peace River & FAS & 100 & 0.01 & 51 \\
\hline WFC: Sweetwater West & Polk & Peace River & FAS & 100 & 0.09 & 633 \\
\hline Winter Haven, city of & Polk & Peace River & FAS & 100 & 7.35 & 30,011 \\
\hline Winter Paradise/Rollar & Polk & Peace River & FAS & 100 & 0.03 & 197 \\
\hline Crescent, city of & Putnam & Lower St. Johns River & FAS & 100 & 0.34 & 2,485 \\
\hline Interlachen, town of & Putnam & Oklawaha River & FAS & 100 & 0.08 & 1,160 \\
\hline Lake Como W/A & Putnam & Lower St. Johns River & FAS & 100 & 0.02 & 322 \\
\hline Melrose W/A & Putnam & Santa Fe River & FAS & 100 & 0.09 & 893 \\
\hline Palatka, city of & Putnam & Lower St. Johns River & FAS & 100 & 2.42 & 14,460 \\
\hline SSU - Putnam Co. totals & Putnam & Lower St. Johns River & FAS & 100 & 0.20 & 3,223 \\
\hline Anastasia/Mainland W/S & St. Johns & Daytona - St. Augustine & USA and FAS & $75 / 25$ & 2.17 & 17,949 \\
\hline Fountain Condominums & St. Johns & Daytona - St. Augustine & FAS & 100 & 0.04 & 392 \\
\hline Fruit Cove Oaks S/D & St. Johns & Lower St. Johns River & FAS & 100 & 0.06 & 450 \\
\hline GDU-Julington Creek S/D & St. Johns & Lower St. Johns River & FAS & 100 & 0.04 & 276 \\
\hline Hastings, city of & St. Johns & Lower St. Johns River & USA and FAS & $80 / 20$ & 0.11 & 595 \\
\hline Intercoastal Utilities & St. Johns & Lower St. Johns River & FAS & 100 & 0.72 & 3,755 \\
\hline North Beach W/S & St. Johns & Daytona - St. Augustine & FAS & 100 & 0.21 & 1,244 \\
\hline
\end{tabular}


Appendix 1. Public-supply water use by utility in the Georgia-Florida Coastal Plain study unit, 1990 - Continued This appendix is divided into the following sections: A. Within Florida. B. Within Georgia.

[A. Florida. [Modified from Marella, 1993; Mgal/d, million gallons per day; FAS, Floridan aquifer system; Ut., utility; MHP, mobile home park; S/D, sub division; USA, unnamed surficial aquifers; GDU, General Developement Utilities; W/A, water association; SSU, Southern States Utilities; WRWSA, Withlacoochee Regional Water Supply Authority; Ser., service; W/S, water system; Co., county; WCRWSA, West Coast Regional Water Supply Authority: UIF, Utilities Incorporated of Florida; Vil., village; Comm., commission; MHU, Mad Hatter Utilities; PCU, Pasco County Utilities; N/A, not available; WF, wellfield; Ent., enterprises; PCWS, Pinellas County Water System; PCBoCC, Polk County Board of County Commissioners; WFC, West Florida Community; Bch., Beach; Riv., River]

\begin{tabular}{|c|c|c|c|c|c|c|}
\hline \multirow{2}{*}{ Utility/Owner } & \multirow{2}{*}{ County } & \multirow{2}{*}{ Cataloging unit } & \multicolumn{2}{|c|}{ Water source } & \multirow{2}{*}{$\begin{array}{c}1990 \\
\text { Mgal/d }\end{array}$} & \multirow{2}{*}{$\begin{array}{c}1990 \\
\text { Population } \\
\text { served }\end{array}$} \\
\hline & & & Name & Percent & & \\
\hline Palm Valley W/S & St. Johns & Lower St. Johns River & FAS & 100 & 0.12 & 459 \\
\hline Ponce DeLeon Utilities & St. Johns & Daytona - St. Augustine & FAS & 100 & 0.05 & 360 \\
\hline Ponte Vedra Utilities & St. Johns & Daytona - St. Augustine & FAS & 100 & 0.84 & 4,263 \\
\hline South Ponte Vedra Beach & St. Johns & Daytona - St. Augustine & FAS & 100 & 0.08 & 718 \\
\hline SSU - Remington Forest & St. Johns & Lower St. Johns River & FAS & 100 & 0.02 & 98 \\
\hline St. Augustine, city of & St. Johns & Daytona - St. Augustine & USA and FAS & $80 / 20$ & 1.83 & 18,457 \\
\hline St. Augustine Shores & St. Johns & Daytona - St. Augustine & USA & 100 & 0.38 & 5.463 \\
\hline St. Johns North Utility & St. Johns & Lower St. Johns River & FAS & 100 & 0.08 & 381 \\
\hline St. Johns Ser. Company & St. Johns & Daytona - St. Augustine & FAS & 100 & 1.55 & 10,878 \\
\hline Wesley Manor W/S & St. Johns & Lower St. Johns River & FAS & 100 & 0.08 & 400 \\
\hline Altamonte Springs, city of & Seminole & Upper St. Johns River & FAS & 100 & 8.00 & 34,879 \\
\hline Casselberry, city of & Seminole & Upper St. Johns River & FAS & 100 & 5.98 & 46,464 \\
\hline Indian Creek Utilities & Seminole & Upper St. Johns River & FAS & 100 & 0.06 & 277 \\
\hline Lake Harney W/A & Seminole & Upper St. Johns River & FAS & 100 & 0.03 & 449 \\
\hline Lake Mary, city of & Seminole & Upper St. Johns River & FAS & 100 & 1.14 & 5,929 \\
\hline Longwood, city of & Seminole & Upper St. Johns River & FAS & 100 & 2.21 & 13,316 \\
\hline Luthern Haven W/S & Seminole & Upper St. Johns River & FAS & 100 & 0.04 & 435 \\
\hline Mullet Lake W/A & Seminole & Upper St. Johns River & FAS & 100 & 0.04 & 550 \\
\hline Oviedo, city of & Seminole & Upper St. Johns River & FAS & 100 & 1.99 & 11,114 \\
\hline Palm Ventures MHP & Seminole & Upper St. Johns River & FAS & 100 & 0.16 & 687 \\
\hline Sanford, city of & Seminole & Upper St. Johns River & FAS & 100 & 5.63 & 32,063 \\
\hline Sanlando Utilities & Seminole & Upper St. Johns River & FAS & 100 & 10.43 & 39,113 \\
\hline Seminole County Water & Seminole & Upper St. Johns River & FAS & 100 & 9.15 & 41,754 \\
\hline SSU - Seminole Co, totals & Seminole & Upper St. Johns River & FAS & 100 & 1.43 & 9,615 \\
\hline UIF - Seminole Co. totals & Seminole & Upper St. Johns River & FAS & 100 & 0.90 & 10,905 \\
\hline Winter Springs, city of & Seminole & Upper St. Johns River & FAS & 100 & 3.60 & 23.241 \\
\hline Bushnell, city of & Sumter & Withlacoochee River & FAS & 100 & 0.30 & 746 \\
\hline Center Hill, city of & Sumter & Withlacoochee River & FAS & 100 & 0.08 & 809 \\
\hline Lake Panasoffkee W/A & Sumter & Withlacoochee River & FAS & 100 & 0.21 & 3,444 \\
\hline Continental Country Club & Sumter & Withlacoochee River & FAS & 100 & 0.46 & 2,303 \\
\hline Gordon, Nathan & Sumter & Withlacoochee River & FAS & 100 & 0.02 & 107 \\
\hline Red Barn MHP & Sumter & Withlacoochee River & FAS & 100 & 0.04 & 350 \\
\hline Webster, city of & Sumter & Withlacoochee River & FAS & 100 & 0.11 & 746 \\
\hline Wildwood, city of & Sumter & Withlacoochee River & FAS & 100 & 0.68 & 3,747 \\
\hline Dowling Park W/S & Suwannee & Lower Suwannee River & FAS & 100 & 0.11 & 350 \\
\hline Branford, town of & Suwannee & Lower Suwannee River & FAS & 100 & 0.11 & 945 \\
\hline Friars Trailer Park & Suwannee & Lower Suwannee River & FAS & 100 & 0.04 & 275 \\
\hline Live Oak, city of & Suwannee & Lower Suwannee River & FAS & 100 & 1.05 & 6.332 \\
\hline Welborn W/A & Suwannee & Lower Suwannee River & FAS & 100 & 0.05 & 543 \\
\hline Keaton Beach W/A & Taylor & Econfina - Steinhatchee & FAS & 100 & 0.02 & 210 \\
\hline Cedar Island W/A & Taylor & Econfina - Steinhatchee & FAS & 100 & 0.01 & 100 \\
\hline Perry, city of & Taylor & Econfina - Steinhatchee & FAS & 100 & 1.20 & 7,062 \\
\hline Stienhatchee W/A & Taylor & Econfina - Steinhatchee & FAS & 100 & 0.16 & 2,248 \\
\hline Taylor Beach W/A & Taylor & Econfina - Steinhatchee & FAS & 100 & 0.03 & 480 \\
\hline
\end{tabular}


Appendix 1. Public-supply water use by utility in the Georgia-Florida Coastal Plain study unit, 1990 —Continued This appendix is divided into the following sections: A. Within Florida. B. Within Georgia.

[A. Florida. [Modified from Marella, 1993; Mgal/d, million gallons per day; FAS, Floridan aquifer system; Ut., utility; MHP, mobile home park; S/D, sub division; USA, unnamed surficial aquifers; GDU, General Developement Utilities; W/A, water association; SSU, Southern States Utilities; WRWSA, Withlacoochee Regional Water Supply Authority; Ser., service; W/S, water system; Co., county; WCRWSA, West Coast Regional Water Supply Authority; UIF, Utilities Incorporated of Florida; Vil., village; Comm., commission; MHU, Mad Hatter Utilities; PCU, Pasco County Utilities; N/A, not available; WF, wellfield; Ent., enterprises; PCWS, Pinellas County Water System; PCBoCC, Polk County Board of County Commissioners; WFC, West Florida Community; Bch., Beach; Riv., River]

\begin{tabular}{|c|c|c|c|c|c|c|}
\hline \multirow{2}{*}{ Utility/Owner } & \multirow{2}{*}{ County } & \multirow{2}{*}{ Cataloging unit } & \multicolumn{2}{|c|}{ Water source } & \multirow{2}{*}{$\begin{array}{c}1990 \\
\text { Mgal/d }\end{array}$} & \multirow{2}{*}{$\begin{array}{c}1990 \\
\text { Population } \\
\text { served }\end{array}$} \\
\hline & & & Name & Percent & & \\
\hline Lake Butler, city of & Union & Santa Fe River & FAS & 100 & 0.63 & 2,116 \\
\hline Cassadaga W/A & Volusia & Upper St. Johns River & FAS & 100 & 0.02 & 273 \\
\hline Daytona Beach. city of & Volusia & Daytona - St. Augustine & FAS & 100 & 12.11 & 80,003 \\
\hline Deland, city of & Volusia & Upper St. Johns River & FAS & 100 & 3.70 & 32,966 \\
\hline Edgewater, city of & Volusia & Cape Canaveral Coastal & FAS & 100 & 1.65 & 15,337 \\
\hline Hacienda Del Rio W/A & Volusia & Upper St. Johns River & FAS & 100 & 0.06 & 606 \\
\hline Halifax Plantation & Volusia & Daytona - St. Augustine & FAS & 100 & 0.04 & 210 \\
\hline Highland Country Estates & Volusia & Upper St. Johns River & FAS & 100 & 0.26 & 671 \\
\hline Holly Hill, city of & Volusia & Daytona - St. Augustine & FAS & 100 & 1.07 & 11,141 \\
\hline John Knox Village & Volusia & Upper St. Johns River & FAS & 100 & 0.07 & 700 \\
\hline Kingston Shores W/A & Volusia & Daytona - St. Augustine & FAS & 100 & 0.02 & 250 \\
\hline Lake Beresford W/A & Volusia & Upper St. Johns River & FAS & 100 & 0.18 & 986 \\
\hline Lake Helen, city of & Volusia & Upper St. Johns River & FAS & 100 & 0.23 & 2,344 \\
\hline New Smyrna Beach,city of & Volusia & Daytona - St. Augustine & FAS & 100 & 4.12 & 27.751 \\
\hline Orange City Country Vil. & Volusia & Upper St. Johns River & FAS & 100 & 0.20 & 1,340 \\
\hline Orange City, city of & Volusia & Upper St. Johns River & FAS & 100 & 0.64 & 5,347 \\
\hline Ormond Beach, city of & Volusia & Daytona - St. Augustine & FAS & 100 & 4.76 & 45,678 \\
\hline Pierson, town of & Volusia & Upper St. Johns River & FAS & 100 & 0.04 & 650 \\
\hline Port Orange, city of & Volusia & Daytona - St. Augustine & FAS & 100 & 4.81 & 42,802 \\
\hline South Water Front Park & Volusia & Daytona - St. Augustine & FAS & 100 & 0.02 & 610 \\
\hline SSU - Deltona Utilities & Volusia & Upper St. Johns River & FAS & 100 & 8.95 & 42,416 \\
\hline SSU - Sugar Mill & Volusia & Daytona - St. Augustine & FAS & 100 & 0.12 & 1,347 \\
\hline Terra Marie Village W/S & Volusia & Upper St. Johns River & FAS & 100 & 0.02 & 200 \\
\hline Tomoka View W/A & Volusia & Daytona - St. Augustine & FAS & 100 & 0.05 & 387 \\
\hline Tymber Creek Utilities & Volusia & Daytona - St. Augustine & FAS & 100 & 0.10 & 792 \\
\hline Volusia County Water & Volusia & Upper St. Johns River & FAS & 100 & 0.97 & 6,828 \\
\hline Panacea Area W/S & Wakulla & Apalachee Bay - St.Marks & FAS & 100 & 0.21 & 2,160 \\
\hline St. Marks, town of & Wakulla & Apalachee Bay - St.Marks & FAS & 100 & 0.07 & 486 \\
\hline Sopchoppy, city of & Wakulla & Lower Ochlockonee River & FAS & 100 & 0.25 & 2,340 \\
\hline Talquin Electric & Wakulla & Apalachee Bay - St.Marks & FAS & 100 & 0.22 & 2,244 \\
\hline Wakulla W/S & Wakulla & Apalachee Bay - St.Marks & FAS & 100 & 0.02 & 165 \\
\hline
\end{tabular}


Appendix 1. Public supply water-use by by utility in the Georgia-Florida Coastal Plain study unit, 1990 B. Georgia.

[Modified from Fanning and others, 1992; Mgal/d, million gallons per day; FAS, Floridan aquifer system; CST, Crystaline Rock aquifer; W/S, Water and Sewer; CLB, Claiborne aquifer; Assoc., Association; N/A, data not available; Auth., Authority; CRE, Cretaceous aquifer]

\begin{tabular}{|c|c|c|c|c|c|c|}
\hline \multirow{2}{*}{ Utility/Owner } & \multirow{2}{*}{ County } & \multirow{2}{*}{ Cataloging unit } & \multicolumn{2}{|l|}{ Water source } & \multirow{2}{*}{$\begin{array}{l}\text { Water } \\
\text { use in } \\
\text { Mgal/d }\end{array}$} & \multirow{2}{*}{$\begin{array}{l}\text { Population } \\
\text { served }\end{array}$} \\
\hline & & & Name & Percent & & \\
\hline Baxley, city of & Appling & Little Satilla River & FAS & 100 & 0.44 & 5.349 \\
\hline Surrency, town of & Appling & Little Satilla River & FAS & 100 & 0.04 & 244 \\
\hline Pearson, city of & Atkinson & Satilla River & FAS & 100 & 0.06 & 1,850 \\
\hline Willacoochee, town of & Atkinson & Satilla River & FAS & 100 & 0.11 & 1,635 \\
\hline Alma, city of & Bacon & Satilla River & FAS & 100 & 0.41 & 3,819 \\
\hline Milledgeville, city of & Baldwin & Lower Oconee River & Oconee River & 100 & 4.75 & 25,000 \\
\hline Auburn, town of & Barrow & Upper Oconee River & CST & 100 & 0.06 & 657 \\
\hline Statham, city of & Barrow & Upper Oconee River & Cedar Creek & 100 & 0.04 & 2,086 \\
\hline Winder, city of & Barrow & Upper Oconee River & Mulberry River & 100 & 3.18 & 14.000 \\
\hline Fitzgerald, city of & Ben Hill & Alapaha River & FAS & 100 & 1.18 & 10,000 \\
\hline Alapaha, town of & Berrien & Alapaha River & FAS & 100 & 0.02 & 672 \\
\hline Enigma, town of & Berrien & Withlacoochee River & FAS & 100 & 0.03 & 600 \\
\hline Nashville, city of & Berrien & Withlacoochee River & FAS & 100 & 0.20 & 4,718 \\
\hline Ray City, city of & Berrien & Withlacoochee River & FAS & 100 & 0.05 & 475 \\
\hline Macon-Bibb County W/S & Bibb & Upper Ocmulgee River & Ocmulgee River & 100 & 24.30 & 143.262 \\
\hline Cochran, city of & Bleckley & Lower Ocmulgee River & FAS and CLB & $60 / 40$ & 0.96 & 6,000 \\
\hline Hoboken, city of & Brantley & Satilla River & FAS & 100 & 0.21 & 435 \\
\hline Nahunta, city of & Brantley & Satilla River & FAS & 100 & 0.14 & 1,106 \\
\hline Barwick, town of & Brooks & Withlacoochee River & FAS & 100 & 0.07 & 450 \\
\hline Morven, city of & Brooks & Little River & FAS & 100 & 0.08 & 461 \\
\hline Quitman, city of & Brooks & Withlacoochee River & FAS & 100 & 1.07 & 5.400 \\
\hline Pembroke, city of & Bryan & Canoochee Creek & FAS & 100 & 0.11 & 1,555 \\
\hline Richmond Hill, city of & Bryan & Lower Ogeechee River & FAS & 100 & 0.41 & 1,500 \\
\hline Brooklet, town of & Bulloch & Lower Ogeechee River & FAS & 100 & 0.10 & 1,200 \\
\hline Nevils Water Assoc. & Bulloch & Canoochee Creek & FAS & 100 & 0.02 & 180 \\
\hline Portal, town of & Bulloch & Lower Ogeechee River & FAS & 100 & 1.30 & 519 \\
\hline Register, town of & Bulloch & Canoochee Creek & FAS & 100 & 0.01 & 280 \\
\hline Statesboro, city of & Bulloch & Canoochee Creek & FAS & 100 & 2.62 & 23,400 \\
\hline Midville, city of & Burke & Upper Ogeechee River & CLB & 100 & 0.11 & 840 \\
\hline Vidette, city of & Burke & Upper Ogeechee River & CLB & 100 & 0.01 & 90 \\
\hline Flovilla, city of & Butts & Upper Ocmulgee River & CST & 100 & 0.09 & 1,030 \\
\hline Jackson, city of & Butts & Upper Ocmulgee River & Yellow Creek & 100 & 1.03 & 5,418 \\
\hline Jenkinsburg, town of & Butts & Upper Ocmulgee River & CST & 100 & 0.06 & 203 \\
\hline Kingsland, city of & Camden & St. Marys River & FAS & 100 & 0.48 & 6,500 \\
\hline St. Marys, city of & Camden & St. Marys River & FAS & 100 & 1.11 & 6,000 \\
\hline Woodbine, city of & Camden & Satilla River & FAS & 100 & 0.14 & 1,200 \\
\hline Metter, city of & Candler & Canoochee Creek & FAS & 100 & 0.66 & 3,531 \\
\hline Pulaski, town of & Candler & Canoochee Creek & FAS & 100 & 0.03 & 263 \\
\hline Folkston, city of & Charlton & St. Marys River & FAS & 100 & 0.67 & 3,700 \\
\hline Savannah, city of & Chatham & Ogeechee Coastal & FAS & 100 & 22.41 & 123,542 \\
\hline Skidway Island Utilities & Chatham & Ogeechee Coastal & FAS & 100 & 0.41 & 1,264 \\
\hline Thunderbolt, town of & Chatham & Ogeechee Coastal & FAS & 100 & 0.43 & 3,915 \\
\hline Tybee Island, city of & Chatham & Ogeechee Coastal & FAS & 100 & 0.25 & 2,700 \\
\hline Athens, city of & Clarke & Upper Oconee River & Middle Oconee River & 100 & 15.13 & 69,779 \\
\hline Clayton County Water Auth. & Clayton & Upper Ocmulgee River & Little Cotton Indian Creek & N/A & N/A & N/A \\
\hline Dupont, town of & Clinch & Upper Suwannee River & FAS & 100 & 0.01 & 111 \\
\hline Homerville, city of & Clinch & Upper Suwannee River & FAS & 100 & 0.32 & 3,400 \\
\hline
\end{tabular}


Appendix 1. Public supply water-use by by utility in the Georgia-Florida Coastal Plain study unit, 1990 —Continued B. Georgia.

[Modified from Fanning and others, 1992; Mgal/d, million gallons per day; FAS, Floridan aquifer system: CST, Crystaline Rock aquifer; W/S, Water and Sewer; CLB, Claiborne aquifer; Assoc., Association; N/A, data not available; Auth., Authority; CRE, Cretaceous aquifer]

\begin{tabular}{|c|c|c|c|c|c|c|}
\hline \multirow{2}{*}{ Utility/Owner } & \multirow{2}{*}{ County } & \multirow{2}{*}{ Cataloging unit } & \multicolumn{2}{|c|}{ Water source } & \multirow{2}{*}{$\begin{array}{l}\text { Water } \\
\text { use in } \\
\text { Mgal/d }\end{array}$} & \multirow{2}{*}{$\begin{array}{l}\text { Population } \\
\text { served }\end{array}$} \\
\hline & & & Name & Percent & & \\
\hline Ambrose, city of & Coffee & Satilla River & FAS & 100 & 0.04 & 410 \\
\hline Broxton, city of & Coffee & Satilla River & FAS & 100 & 0.15 & 1,117 \\
\hline Douglas, City of & Coffee & Satilla River & FAS & 100 & 3.77 & 13,500 \\
\hline Nicholls, city of & Coffee & Satilla River & FAS & 100 & 0.13 & 1,300 \\
\hline Berlin, town of & Colquitt & Withlacoochee River & FAS & 100 & 0.02 & 500 \\
\hline Doerun, city of & Colquitt & Upper Ochlockonee River & FAS & 100 & 0.09 & 1.046 \\
\hline Ellenton, town of & Colquitt & Little River & FAS & 100 & 0.01 & 345 \\
\hline Funston, town of & Colquitt & Upper Ochlockonee River & FAS & 100 & 0.03 & 249 \\
\hline Moultrie, city of & Colquitt & Upper Ochlockonee River & FAS & 100 & 3.22 & 25,000 \\
\hline Norman Park, town of & Colquitt & Little River & FAS & 100 & 0.15 & 709 \\
\hline Riverside, town of & Colquitt & Withlacoochee River & FAS & 100 & 0.04 & 69 \\
\hline Adel, city of & Cook & Withlacoochee River & FAS & 100 & 2.51 & 5,500 \\
\hline Cecil, town of & Cook & Withlacoochee River & FAS & 100 & 0.10 & 359 \\
\hline Lenox, town of & Cook & Withlacoochee River & FAS & 100 & 0.09 & 1,100 \\
\hline Sparks, town of & Cook & Withlacoochee River & FAS & 100 & 0.16 & 1,500 \\
\hline Arabi, town of & Crisp & Alapaha River & FAS & 100 & 0.07 & 413 \\
\hline Attapulgus, town of & Decatur & Lower Ochlockonee River & FAS & 100 & 0.10 & 380 \\
\hline Climax, town of & Decatur & Lower Ochlockonee River & FAS & 100 & 0.02 & 107 \\
\hline Chauncey, town of & Dodge & Little Ocmulgee River & FAS & 100 & 0.03 & 312 \\
\hline Chester, town of & Dodge & Little Ocmulgee River & FAS & 100 & 0.04 & 886 \\
\hline Eastman, city of & Dodge & Little Ocmulgee River & FAS and CLB & $80 / 20$ & 0.72 & 6,000 \\
\hline Rhine, town of & Dodge & Lower Ocmulgee River & FAS & 100 & 0.07 & 465 \\
\hline Pinehurst, city of & Dooly & Lower Ocmulgee River & CLB & 100 & 0.03 & 143 \\
\hline Unadilla, city of & Dooly & Lower Ocmulgee River & CLB & 100 & 0.19 & 2,100 \\
\hline Echols County Water Assoc. & Echols & Alapaha River & FAS & 100 & 0.06 & 450 \\
\hline Guyton, city of & Effingham & Lower Ogeechee River & FAS & 100 & 0.17 & 800 \\
\hline Adrian, city of & Emanuel & Ohoopee River & FAS & 100 & 0.10 & 750 \\
\hline Garfield, town of & Emanuel & Canoochee Creek & FAS & 100 & 0.03 & 226 \\
\hline Nunez, town of & Emanuel & Ohoopee River & FAS & 100 & 0.01 & 135 \\
\hline Oak Park, town of & Emanuel & Ohoopee River & FAS & 100 & 0.03 & 266 \\
\hline Stillmore, town of & Emanuel & Ohoopee River & FAS & 100 & 0.04 & 610 \\
\hline Summertown, town of & Emanuel & Upper Ogeechee River & FAS & 100 & 0.01 & 151 \\
\hline Swainsboro, town of & Emanuel & Ohoopee River & FAS & 100 & 1.94 & 8,100 \\
\hline Twin City, city of & Emanuel & Canoochee Creek & FAS & 100 & 0.13 & 2,500 \\
\hline Bellville, city of & Evans & Canoochee Creek & FAS & 100 & 0.04 & 300 \\
\hline Claxton, city of & Evans & Canoochee Creek & FAS & 100 & 0.33 & 3,000 \\
\hline Daisy, city of & Evans & Canoochee Creek & FAS & 100 & 0.02 & 138 \\
\hline Hagan, city of & Evans & Canoochee Creek & FAS & 100 & 0.09 & 900 \\
\hline Hapeville, city of & Fulton & Upper Ocmulgee River & Purchased & 100 & N/A & 4,800 \\
\hline Gibson, city of & Glascock & Upper Ogeechee River & CLB & 100 & 0.10 & 679 \\
\hline Mitchell, city of & Glascock & Upper Ogeechee River & CST & 100 & 0.02 & 188 \\
\hline Brunswick, city of & Glynn & Cumberland - St. Simons & FAS & 100 & 6.34 & 25,480 \\
\hline Brunswick-Glynco W/S & Glynn & Cumberland - St. Simons & FAS & 100 & 0.33 & 11,605 \\
\hline Brunswick-Interchange Water & Glynn & Cumberland - St. Simons & FAS & 100 & 0.47 & 300 \\
\hline Sea Palms Development Water & Glynn & Cumberland - St. Simons & FAS & 100 & 0.46 & N/A \\
\hline Jekyll Island Water System & Glynn & Cumberland - St. Simons & FAS & 100 & 1.40 & 2,500 \\
\hline St. Simons Island W/S & Glynn & Cumberland - St. Simons & FAS & 100 & 2.48 & 6,904 \\
\hline Sea Island Services & Glynn & Cumberland - St. Simons & FAS & 100 & 1.43 & 1,000 \\
\hline
\end{tabular}


Appendix 1. Public supply water-use by by utility in the Georgia-Florida Coastal Plain study unit, 1990 -Continued B. Georgia.

[Modified from Fanning and others, 1992; Mgal/d, million gallons per day; FAS. Floridan aquifer system: CST, Crystaline Rock aquifer; W/S, Water and Sewer; CLB, Claiborne aquifer; Assoc., Association; N/A, data not available; Auth., Authority; CRE, Cretaceous aquifer]

\begin{tabular}{|c|c|c|c|c|c|c|}
\hline \multirow{2}{*}{ Utility/Owner } & \multirow{2}{*}{ County } & \multirow{2}{*}{ Cataloging unit } & \multicolumn{2}{|c|}{ Water source } & \multirow{2}{*}{$\begin{array}{l}\text { Water } \\
\text { use in } \\
\text { Mgal/d }\end{array}$} & \multirow{2}{*}{$\begin{array}{l}\text { Population } \\
\text { served }\end{array}$} \\
\hline & & & Name & Percent & & \\
\hline Cairo, city of & Grady & Upper Ochlockonee River & FAS & 100 & 1.46 & 9,035 \\
\hline Whigham, city of & Grady & Upper Ochlockonee River & FAS & 100 & 0.09 & 604 \\
\hline Greensboro, city of & Greene & Upper Oconee River & Lake Oconee & 100 & 0.53 & 2,930 \\
\hline Siloam, town of & Greene & Upper Oconee River & CST & 100 & 0.02 & 161 \\
\hline Union Point, city of & Greene & Upper Ogeechee River & Sherrill Creek & 100 & 0.23 & 2,010 \\
\hline White Plains, town of & Greene & Upper Oconee River & CST & 100 & 0.02 & 283 \\
\hline Woodville & Greene & Upper Oconee River & CST & 100 & 0.01 & 204 \\
\hline Dacula, city of & Gwinnett & Upper Oconee River & CST & 100 & 0.16 & 2,080 \\
\hline Grayson, city of & Gwinnett & Upper Ocmulgee River & CST & 100 & 0.03 & 527 \\
\hline Devereux Water System & Hancock & Upper Oconee River & CST & 100 & 0.02 & 267 \\
\hline Sparta, city of & Hancock & Lower Oconee River & Ford Creek & 100 & 0.39 & 3,110 \\
\hline Hampton. city of & Henry & Upper Ocmulgee River & CST & 100 & 0.08 & 1,800 \\
\hline Henry County Water Auth. & Henry & Upper Ocmulgee River & Towaliga River & 100 & 4.38 & 20,100 \\
\hline Locust Grove, city of & Henry & Upper Ocmulgee River & Indian Creek & 100 & 0.05 & 1,545 \\
\hline McDonough, city of & Henry & Upper Ocmulgee River & Walnut Creek and CST & $88 / 12$ & 0.76 & 3,740 \\
\hline Centerville, city of & Houston & Lower Ocmulgee River & CRE & 100 & 0.77 & 5,606 \\
\hline Elberta, city of & Houston & Lower Ocmulgee River & CRE & 100 & 0.11 & 1,559 \\
\hline Houston County W/S & Houston & Lower Ocmulgee River & CRE & 100 & 3.19 & 3,540 \\
\hline Perry, city of & Houston & Lower Ocmulgee River & CRE & 100 & 1.58 & 11,612 \\
\hline Warner Robins, city of & Houston & Lower Ocmulgee River & CRE & 100 & 6.51 & 51,000 \\
\hline Irwinville Water Works & Irwin & Alapaha River & FAS & 100 & 0.03 & 300 \\
\hline Mystic, city of & Irwin & Alapaha River & FAS & 100 & 0.03 & 300 \\
\hline Ocilla, city of & Irwin & Alapaha River & FAS & 100 & 0.62 & 3,200 \\
\hline Braselton, town of & Jackson & Upper Oconee River & CST & 100 & 0.05 & 650 \\
\hline Commerce, city of & Jackson & Upper Oconee River & Grove Creek & 100 & 1.26 & 5,000 \\
\hline Hoschton, city of & Jackson & Upper Oconee River & CST & 100 & 0.04 & 590 \\
\hline Jefferson, city of & Jackson & Upper Oconee River & Big Curry Creek & 100 & 1.06 & 3,000 \\
\hline Nicholson Water Assoc. & Jackson & Upper Oconee River & CST & 100 & 0.12 & 536 \\
\hline Monticello, city of & Jasper & Upper Oconee River & Popes Branch & 100 & 0.24 & 3,080 \\
\hline Shady Dale, town of & Jasper & Upper Oconee River & CST & 100 & 0.10 & 320 \\
\hline Denton, city of & Jeff Davis & Satilla River & FAS & 100 & 0.04 & 700 \\
\hline Hazelhurst, city of & Jeff Davis & Altamaha River & FAS & 100 & 0.95 & 4,298 \\
\hline Avera, town of & Jefferson & Upper Ogeechee River & CLB & 100 & 0.02 & 248 \\
\hline Bartow, town of & Jefferson & Upper Ogeechee River & CLB & 100 & 0.01 & 427 \\
\hline Louisville, city of & Jefferson & Upper Ogeechee River & CLB and CRE & 100 & 1.37 & 2,823 \\
\hline Stapleton, town of & Jefferson & Upper Ogeechee River & CLB and CRE & $90 / 10$ & 0.05 & 390 \\
\hline Wadley, city of & Jefferson & Upper Ogeechee River & CLB and FAS & 100 & 0.16 & 2,475 \\
\hline Millen, city of & Jenkins & Upper Ogeechee River & FAS and CLB & 100 & 0.57 & 3,900 \\
\hline Perkins Water Auth. & Jenkins & Upper Ogeechee River & CLB & 100 & 0.01 & 76 \\
\hline Kite, town of & Johnson & Ohoopee River & FAS & 100 & 0.03 & 296 \\
\hline Scott W/S Auth. & Johnson & Ohoopee River & FAS & 100 & 0.02 & 250 \\
\hline Wrightsville, city of & Johnson & Ohoopee River & FAS and CLB & 100 & 0.22 & 2,540 \\
\hline Gray, city of & Jones & Upper Ocmuglee River & CST & 100 & 0.03 & 3,000 \\
\hline Haddock Water Commission & Jones & Lower Oconee River & CST & 100 & 0.06 & 800 \\
\hline Jones County Water Auth. & Jones & Upper Ocmuglee River & CRE & 100 & 0.70 & 6,300 \\
\hline Barnesville, city of & Lamar & Upper Ocmuglee River & $\begin{array}{c}\text { Edie Creek and } \\
\text { Big Towaliga Creek }\end{array}$ & N/A & 1.51 & 5,600 \\
\hline Lakeland, city of & Lanier & Alapaha River & FAS & 100 & 0.34 & 2,647 \\
\hline
\end{tabular}


Appendix 1. Public supply water-use by by utility in the Georgia-Florida Coastal Plain study unit, 1990 -Continued B. Georgia.

[Modified from Fanning and others, 1992; Mgal/d, million gallons per day; FAS, Floridan aquifer system; CST, Crystaline Rock aquifer: W/S. Water and Sewer; CLB, Claiborne aquifer: Assoc., Association; N/A, data not available; Auth., Authority; CRE, Cretaceous aquifer]

\begin{tabular}{|c|c|c|c|c|c|c|}
\hline \multirow{2}{*}{ Utility/Owner } & \multirow{2}{*}{ County } & \multirow{2}{*}{ Cataloging unit } & \multicolumn{2}{|c|}{ Water source } & \multirow{2}{*}{$\begin{array}{l}\text { Water } \\
\text { use in } \\
\text { Mgal/d }\end{array}$} & \multirow{2}{*}{$\begin{array}{l}\text { Population } \\
\text { served }\end{array}$} \\
\hline & & & Name & Percent & & \\
\hline Cadwell, town of & Laurens & Little Ocmulgee River & FAS & 100 & 0.06 & 464 \\
\hline Dexter, town of & Laurens & Lower Oconee River & FAS & 100 & 0.03 & 465 \\
\hline Dublin, city of & Laurens & Lower Oconee River & Oconee River and FAS & $80 / 20$ & 3.34 & 19,099 \\
\hline Dudley, city of & Laurens & Lower Oconee River & CLB & 100 & 0.06 & 403 \\
\hline East Dublin, town of & Laurens & Lower Oconee River & CLB & 100 & 0.38 & 3,200 \\
\hline Montrose, town of & Laurens & Lower Oconee River & FAS and CLB & $50 / 50$ & 0.02 & 117 \\
\hline Rentz, town of & Laurens & Lower Oconee River & FAS & 100 & 0.04 & 364 \\
\hline Hinesville, city of & Liberty & Ogeechee Coastal & FAS & 100 & 2.14 & 21,000 \\
\hline Midway, city of & Liberty & Ogeechee Coastal & FAS & 100 & 0.02 & 800 \\
\hline Walthourville, city of & Liberty & Ogeechee Coastal & FAS & 100 & 0.23 & 15,000 \\
\hline Ludowici, city of & Long & Altamaha River & FAS & 100 & 0.14 & 2,000 \\
\hline Clyattville, town of & Lowndes & Withlachoochee River & FAS & 100 & 0.03 & 300 \\
\hline Hahira, city of & Lowndes & Little River & FAS & 100 & 0.03 & 1,800 \\
\hline Lake Park, town of & Lowndes & Alapaha River & FAS & 100 & 0.04 & 433 \\
\hline Lowndes County Water System & Lowndes & Alapaha River & FAS & 100 & 0.18 & 1,364 \\
\hline Remerton, city of & Lowndes & Withlachoochee River & FAS & 100 & 0.04 & 443 \\
\hline Valdosta, city of & Lowndes & Alapaha River & FAS & 100 & 7.47 & 43,000 \\
\hline Darien, city of & Mclntosh & Ogeechee Coastal & FAS & 100 & 0.11 & 3,000 \\
\hline Hog Hammock Community & McIntosh & Ogeechee Coastal & FAS & 100 & 0.02 & 170 \\
\hline Hinsonton Water Assoc. & Mitchell & Upper Ochlockonee River & FAS & 100 & 0.01 & 60 \\
\hline Pelham, city of & Mitchell & Upper Ochlockonee River & FAS & 100 & 0.69 & 4,300 \\
\hline Sale City, town of & Mitchell & Upper Ochlockonee River & FAS & 100 & 0.05 & 322 \\
\hline Culloden, city of & Monroe & Upper Ocmulgee River & CST & 100 & 0.02 & 121 \\
\hline Forsyth, city of & Monroe & Upper Ocmulgee River & CST & 100 & 1.20 & 6,000 \\
\hline Ailey, town of & Montgomery & Lower Oconee River & FAS & 100 & 0.04 & 555 \\
\hline Alston, town of & Montgomery & Altamaha River & FAS & 100 & 0.01 & 160 \\
\hline Charlotte Water Assoc. & Montgomery & Altamaha River & FAS & 100 & 0.01 & 60 \\
\hline Mt. Vernon, city of & Montgomery & Lower Oconee River & FAS & 100 & 0.19 & 1,737 \\
\hline Tarrytown, village of & Montgomery & Ohoopee River & FAS & 100 & 0.01 & 130 \\
\hline Uvalda, town of & Montgomery & Altamaha River & FAS & 100 & 0.05 & 563 \\
\hline Bostwick, town of & Morgan & Upper Oconee River & CST & 100 & 0.01 & 307 \\
\hline Buckhead, town of & Morgan & Upper Oconee River & CST & 100 & 0.02 & 174 \\
\hline Madison, city of & Morgan & Upper Oconee River & CST/Hard Labor Creek & $92 / 8$ & 1.02 & 984 \\
\hline Rutledge, city of & Morgan & Upper Oconee River & CST & 100 & 0.07 & 659 \\
\hline Almon Community Water & Newton & Upper Ocmulgee River & CST & 100 & 0.04 & 350 \\
\hline Covington, city of & Newton & Upper Ocmulgee River & Alcovy Creek & 100 & 3.37 & 12,000 \\
\hline Mansfield, town of & Newton & Upper Oconee River & CST & 100 & 0.02 & 337 \\
\hline Newborn, town of & Newton & Upper Oconee River & CST & 100 & 0.04 & 388 \\
\hline Porterdale, town of & Newton & Upper Ocmulgee River & CST & 100 & 0.04 & 1,430 \\
\hline Oconee County Water Auth. & Oconee & Upper Oconee River & Calls Creek & 100 & 0.32 & 6,400 \\
\hline Watkinsville, city of & Oconee & Upper Oconee River & CST & 100 & 0.51 & 1,240 \\
\hline Byron, city of & Peach & Lower Ocmulgee River & CRE & 100 & 0.30 & 1,960 \\
\hline Fort Valley, city of & Peach & Lower Ocmulgee River & CRE & 100 & 2.07 & 10,000 \\
\hline Blackshear, city of & Pierce & Little Satilla River & FAS & 100 & 0.47 & 3,465 \\
\hline Patterson, city of & Pierce & Little Satilla River & FAS & 100 & 0.03 & 750 \\
\hline Hartford Water Auth. & Pulaski & Lower Ocmulgee River & CLB & 100 & 0.05 & 650 \\
\hline Hawkinsville, city of & Pulaski & Lower Ocmulgee River & CLB and FAS & $90 / 10$ & 0.62 & 4,400 \\
\hline Eatonton, city of & Putnam & Upper Oconee River & Little River & 100 & 0.85 & 4,832 \\
\hline
\end{tabular}


Appendix 1. Public supply water-use by by utility in the Georgia-Florida Coastal Plain study unit, 1990 -Continued B. Georgia.

[Modified from Fanning and others, 1992; Mgal/d, million gallons per day; FAS, Floridan aquifer system; CST, Crystaline Rock aquifer; W/S. Water and Sewer; CLB, Claiborne aquifer; Assoc., Association; N/A. data not available; Auth., Authority; CRE, Cretaceous aquifer]

\begin{tabular}{|c|c|c|c|c|c|c|}
\hline \multirow{2}{*}{ Utility/Owner } & \multirow{2}{*}{ County } & \multirow{2}{*}{ Cataloging unit } & \multicolumn{2}{|c|}{ Water source } & \multirow{2}{*}{$\begin{array}{l}\text { Water } \\
\text { use in } \\
\text { Mgal/d }\end{array}$} & \multirow{2}{*}{$\begin{array}{l}\text { Population } \\
\text { served }\end{array}$} \\
\hline & & & Name & Percent & & \\
\hline Conyers, city of & Rockdale & Upper Ocmulgee River & CST and Yellow River & $73 / 27$ & 6.14 & 43,214 \\
\hline Milstead Water System & Rockdale & Upper Ocmulgee River & CST & 100 & 0.11 & 1,000 \\
\hline Newington, town of & Screven & Lower Ogeechee River & FAS & 100 & 0.05 & 317 \\
\hline Oliver, city of & Screven & Lower Ogeechee River & FAS & 100 & 0.03 & 214 \\
\hline Sylvania, city of & Screven & Lower Ogeechee River & FAS & 100 & 0.47 & 2,420 \\
\hline Crawfordville, city of & Taliaferro & Upper Ogeechee River & FAS & 100 & 0.03 & 234 \\
\hline Cobbtown, city of & Tattnail & Canoochee Creek & FAS & 100 & 0.07 & 341 \\
\hline Collins, city of & Tattnail & Ohoopee River & FAS & 100 & 0.06 & 750 \\
\hline Glennville, city of & Tattnail & Altamaha River & FAS & 100 & 0.49 & 4,500 \\
\hline Manassas, city of & Tattnail & Canoochee Creek & FAS & 100 & 0.02 & 200 \\
\hline Reidsville, city of & Tattnail & Ohoopee River & FAS & 100 & 0.40 & 3,150 \\
\hline Jacksonville, town of & Telfair & Lower Ocmulgee River & FAS & 100 & 0.03 & 127 \\
\hline Lumber City, city of & Telfair & Little Ocmulgee River & FAS & 100 & 0.90 & 1,500 \\
\hline McRae, city of & Telfair & Little Ocmulgee River & FAS & 100 & 0.20 & 3,409 \\
\hline Milan, town of & Telfair & Little Ocmulgee River & FAS & 100 & 0.41 & 900 \\
\hline Scotland, city of & Telfair & Little Ocmulgee River & FAS & 100 & 0.18 & 236 \\
\hline Boston, city of & Thomas & Aucilla River & FAS & 100 & 0.11 & 1,500 \\
\hline Barwick, town of & Thomas & Withlacoochee River & FAS & 100 & 0.06 & 413 \\
\hline Coolidge, city of & Thomas & Upper Ochlockonee River & FAS & 100 & 0.11 & 610 \\
\hline Meigs, city of & Thomas & Upper Ochlockonee River & FAS & 100 & 0.16 & 1,300 \\
\hline Ochlocknee, town of & Thomas & Upper Ochlockonee River & FAS & 100 & 0.07 & 650 \\
\hline Pavo, city of & Thomas & Withlacoochee River & FAS & 100 & 0.08 & 1,000 \\
\hline Thomasville, city of & Thomas & Aucilla River & FAS & 100 & 3.99 & 24,000 \\
\hline Omega, city of & Tift & Little River & FAS & 100 & 0.07 & 1,058 \\
\hline Tift County Water System & Tift & Withlacoochee River & FAS & 100 & 0.22 & 2,500 \\
\hline Tifton, city of & Tift & Withlacoochee River & FAS & 100 & 5.73 & 28.000 \\
\hline Ty Ty, town of & Tift & Little River & FAS & 100 & 0.08 & 565 \\
\hline Lyons, city of & Toombs & Ohoopee River & FAS & 100 & 0.56 & 4,203 \\
\hline Santa Claus, city of & Toombs & Ohoopee River & FAS & 100 & 0.01 & 164 \\
\hline Vidalia, city of & Toombs & Ohoopee River & FAS & 100 & 1.87 & 11,500 \\
\hline Soperton, city of & Treutlen & Lower Oconee River & FAS & 100 & 0.43 & 3,000 \\
\hline Ashburn, city of & Turner & Little River & FAS & 100 & 0.61 & 4.670 \\
\hline Rebecca, town of & Turner & Alapaha River & FAS & 100 & 0.02 & 390 \\
\hline Sycamore, city of & Turner & Little River & FAS & 100 & 0.10 & 650 \\
\hline Danville, town of & Twiggs & Lower Oconee River & CRE & 100 & 0.03 & 482 \\
\hline Jeffersonville, city of & Twiggs & Lower Oconee River & CRE & 100 & 0.23 & 1,474 \\
\hline Jersey, town of & Walton & Upper Ocmulgee River & CST & 100 & 0.03 & 342 \\
\hline Monroe, city of & Walton & Upper Ocmulgee River & Alcovy River & 100 & 2.77 & 14.866 \\
\hline Social Circle, city of & Walton & Upper Ocmulgee River & Alcovy River & 100 & 0.45 & 2,700 \\
\hline Walton County Water System & Walton & Upper Ocmulgee River & CST & 100 & 0.64 & N/A \\
\hline Manor Water System & Ware & Upper Suwannee River & FAS & 100 & 0.37 & 500 \\
\hline Ware County Water System & Ware & Satilla River & FAS & 100 & 1.27 & 9,000 \\
\hline Waycross, city of & Ware & Satilla River & FAS & 100 & 2.82 & 16,100 \\
\hline Norwood, town of & Warren & Upper Ogeechee River & CST & 100 & 0.01 & 188 \\
\hline Warrenton, city of & Warren & Upper Ogeechee River & Rocky Comfort Creek & 100 & 0.30 & 2.525 \\
\hline Davisboro, city of & Washington & Upper Ogeechee River & CLB and CRE & $67 / 33$ & 0.03 & 382 \\
\hline Deepstep, town of & Washington & Lower Oconee River & CRE & 100 & 0.01 & 86 \\
\hline Harrison, town of & Washington & Ohoopee River & FAS & 100 & 0.02 & 411 \\
\hline
\end{tabular}


Appendix 1. Public supply water-use by by utility in the Georgia-Florida Coastal Plain study unit, 1990 —Continued B. Georgia.

[Modified from Fanning and others, 1992; Mgal/d, million gallons per day: FAS, Floridan aquifer system: CST. Crystaline Rock aquifer: W/S. Water and Sewer; CLB, Claiborne aquifer; Assoc., Association; N/A, data not available; Auth., Authority; CRE, Cretaceous aquifer]

\begin{tabular}{|c|c|c|c|c|c|c|}
\hline \multirow{2}{*}{ Utility/Owner } & \multirow{2}{*}{ County } & \multirow{2}{*}{ Cataloging unit } & \multicolumn{2}{|c|}{ Water source } & \multirow{2}{*}{$\begin{array}{l}\text { Water } \\
\text { use in } \\
\text { Mgal/d }\end{array}$} & \multirow{2}{*}{$\begin{array}{l}\text { Population } \\
\text { served }\end{array}$} \\
\hline & & & Name & Percent & & \\
\hline Oconee, town of & Washington & Lower Oconee River & CRE & 100 & 0.03 & 221 \\
\hline Riddleville, town of & Washington & Ohoopee River & CLB & 100 & 0.11 & 79 \\
\hline Sandersville, city of & Washington & Lower Oconee River & CRE and CLB & $70 / 30$ & 1.44 & 6,148 \\
\hline Tennille, city of & Washington & Ohoopee River & FAS & 100 & 0.19 & 1,717 \\
\hline Warthen Water Auth. & Washingıon & Upper Ogeechee River & CRE & 100 & 0.01 & 240 \\
\hline Jesup, city of & Wayne & Altamaha River & FAS & 100 & 1.62 & 10.000 \\
\hline Odum, town of & Wayne & Little Satilla River & FAS & 100 & 0.02 & 388 \\
\hline Screven, city of & Wayne & Little Satilla River & FAS & 100 & 0.73 & 872 \\
\hline Alamo, city of & Wheeler & Little Ocmulgee River & FAS & 100 & 0.21 & 1,035 \\
\hline Glenwood, city of & Wheeler & Lower Oconee River & FAS & 100 & 0.06 & 1,610 \\
\hline Abbeville, city of & Wilcox & Lower Ocmulgee River & FAS & 100 & 0.08 & 998 \\
\hline Pineview, town of & Wilcox & Lower Ocmulgee River & FAS & 100 & 0.10 & 564 \\
\hline Pitts, city of & Wilcox & Alapaha River & FAS & 100 & 0.02 & 218 \\
\hline Rochelle, city of & Wilcox & Alapaha River & FAS & 100 & 0.40 & 1,642 \\
\hline Seville, town of & Wilcox & Alapaha River & FAS & 100 & 0.01 & 150 \\
\hline Allentown, town of & Wilkinson & Lower Oconee River & CRE & 100 & 0.02 & 241 \\
\hline Gordon, town of & Wilkinson & Lower Oconee River & CRE & 100 & 0.38 & 2,873 \\
\hline Irwinton, town of & Wilkinson & Lower Oconee River & CRE & 100 & 0.20 & 1,250 \\
\hline Ivey, town of & Wilkinson & Lower Oconee River & CRE & 100 & 0.11 & 650 \\
\hline Mcintyre, town of & Wilkinson & Lower Oconee River & CRE & 100 & 0.10 & 571 \\
\hline Toomsboro, town of & Wilkinson & Lower Oconee River & CRE & 100 & 0.12 & 652 \\
\hline Poulan, city of & Worth & Little River & FAS & 100 & 0.05 & 800 \\
\hline Sumner, town of & Worth & Little River & FAS & 100 & 0.03 & 190 \\
\hline Sylvester, city of & Worth & Little River & FAS & 100 & 0.69 & 5,900 \\
\hline
\end{tabular}


Appendix 2. Population and water-use by hydrologic cataloging unit in the Georgia-Florida Coastal Plain study unit, 1990. This appendix is divided into the following sections:

A. Population characteristics. B. Water-use by principal category.

A. Population charactertistics.

[cataloging units are shown on figure 12 and are identified in Seaber and others, 1987]

\begin{tabular}{|c|c|c|c|c|c|}
\hline \multicolumn{3}{|c|}{ Cataloging units } & \multicolumn{3}{|c|}{ Served by public supply } \\
\hline Name & Unit number & Population & Total & Ground water & Surface water \\
\hline Upper Ogeechee River & 03060201 & 43,010 & 18,900 & 13,810 & 5.090 \\
\hline Lower Ogeechee River & 03060202 & 43.770 & 22.880 & 22.880 & 0 \\
\hline Canoochee Creek & 03060203 & 64,620 & 36,510 & 36,510 & 0 \\
\hline Ogeechee Coastal & 03060204 & 200,730 & 152,630 & 144,630 & 8,000 \\
\hline Upper Oconee River & 03070101 & 265,340 & 154,180 & 30710 & 127.179 \\
\hline Lower Oconee River & 03070102 & 116,650 & 75,750 & 30690 & 45.000 \\
\hline Viper ocmilge- River & 03070103 & 1188200 & $1.037,610$ & $577 \% 0$ & $979.82 \%$ \\
\hline Lower Oenufgee Ruer: & 03070104 & 128,870 & 104,880 & 104880 & n \\
\hline Litte Oemulgee Ruver & 03070105 & 31,160 & 17,140 & 17140 & a. \\
\hline Altamahis River & 0sorulat: & 50.970 & 21.670 & 21.670 & 0 \\
\hline Otwcopee Ruver & $0307010 \%$ & 54010 & 31,870 & 31.870 & b. \\
\hline Santhinker & 03070201 & 108550 & 57,570 & 57.570 & 0 \\
\hline Litce Satilla Ríver & 13170202 & 21,000 & 9.330 & 9.330 & a \\
\hline Cimberand - St Simons: & 08070203 & 72,340 & 54,620 & 54,620 & 0 \\
\hline St Mays River & 03070204 & 73510 & 42,020 & 42,020 & 0 \\
\hline Nassall Ruver & 03070205 & 24,790 & 7,650 & 7.650 & \% \\
\hline Upper St. Johns River (1) & 03080101 & 961,276 & 876,630 & 876,630 & 0 \\
\hline Oklawaha River & 03080102 & 446,040 & 328,260 & 328,260 & 0 \\
\hline Lower St. Johns River & 03080103 & 873,250 & 731,700 & 731,700 & 0 \\
\hline Daytona - St. Augustine & 03080201 & 275,030 & 250,510 & 250,510 & 0 \\
\hline Cape Canaveral Coastal & 03080202 & 440,070 & 406,150 & 269,660 & 136,490 \\
\hline Vero Beach Coastal (1) & 03080203 & 91,593 & 53,734 & 53,734 & 0 \\
\hline Kissipunife River (I) & 03090191 & 255.660 & 221,373 & 2213373 & $n$ \\
\hline Peace River (1) & 03100101 & 276,534 & 228,598 & 228,598 & 0 \\
\hline Little Manatee River (1) & 03100203 & 21,000 & 19,500 & 19,500 & 0 \\
\hline Alafia River & 03100204 & 59,430 & 21,780 & 21,780 & 0 \\
\hline Hillsborough River & 03100205 & 623,800 & 590,370 & 205,200 & 385,170 \\
\hline Tampa Bay (1) & 03100206 & 624,263 & 610,786 & 567,990 & 42,796 \\
\hline Crystal - Pithlachascotee & 03100207 & 843,160 & 757,390 & 757,390 & 0 \\
\hline Withlacoochee River & 03100208 & 195,340 & 80,960 & 80.960 & 0 \\
\hline Waccasasse Kuer & 031tomi & $1366 y^{20}$ & 3.910 & 6910 & 6. \\
\hline Econfina - Stowhatchee & 03110102 & 25.940 & 14650 & 14,630 & 0 \\
\hline Anethi River & 08110108 & 33510 & 19080 & 19080 & 0 \\
\hline Vpper Suwannet River & 03110201 & 25,520 & 10,230 & 10,230 & $\theta$ \\
\hline Alrolia Ruer & 102110292 & 384960 & 40350 & 49350 & 9 \\
\hline Winlaciochee Ruer & 03110209 & 113,020 & 93,630 & 93,630 & 0 \\
\hline Little Ruer & 03110204 & 41,380 & 19,250 & 19.250 & 0 \\
\hline loner Sunmmea River & 163110205 & 42,820 & 13.660 & 13.660 & 6 \\
\hline Santa Fe River & 03110206 & 105,360 & 35.470 & 35.470 & \\
\hline Apalachee Bay - St. Marks & 03120001 & 193,960 & 155,260 & 155,260 & 0 \\
\hline Upper Ochlockonee River & 03120002 & 53,510 & 45,300 & 45,300 & 0 \\
\hline Lower Ochlockonee River & 03120003 & 64,580 & 28,020 & 19,600 & 8,420 \\
\hline Totals & & $9,267,386$ & $7,510,761$ & $5.776,445$ & 1.734 .316 \\
\hline
\end{tabular}

(1) Indicates the cataloging unit is partially in the study unit, and the data shown is for the part within the study unit only. 


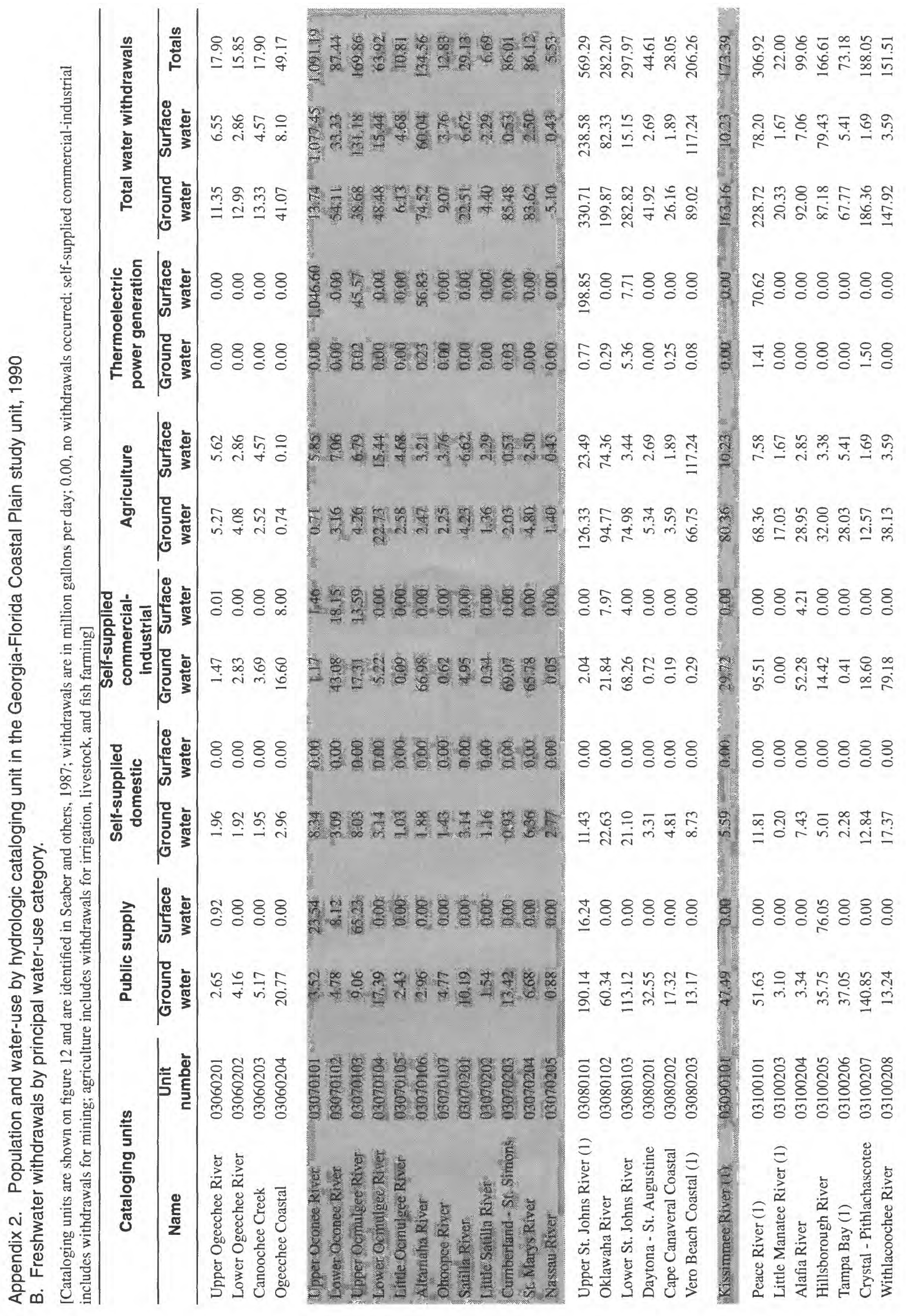




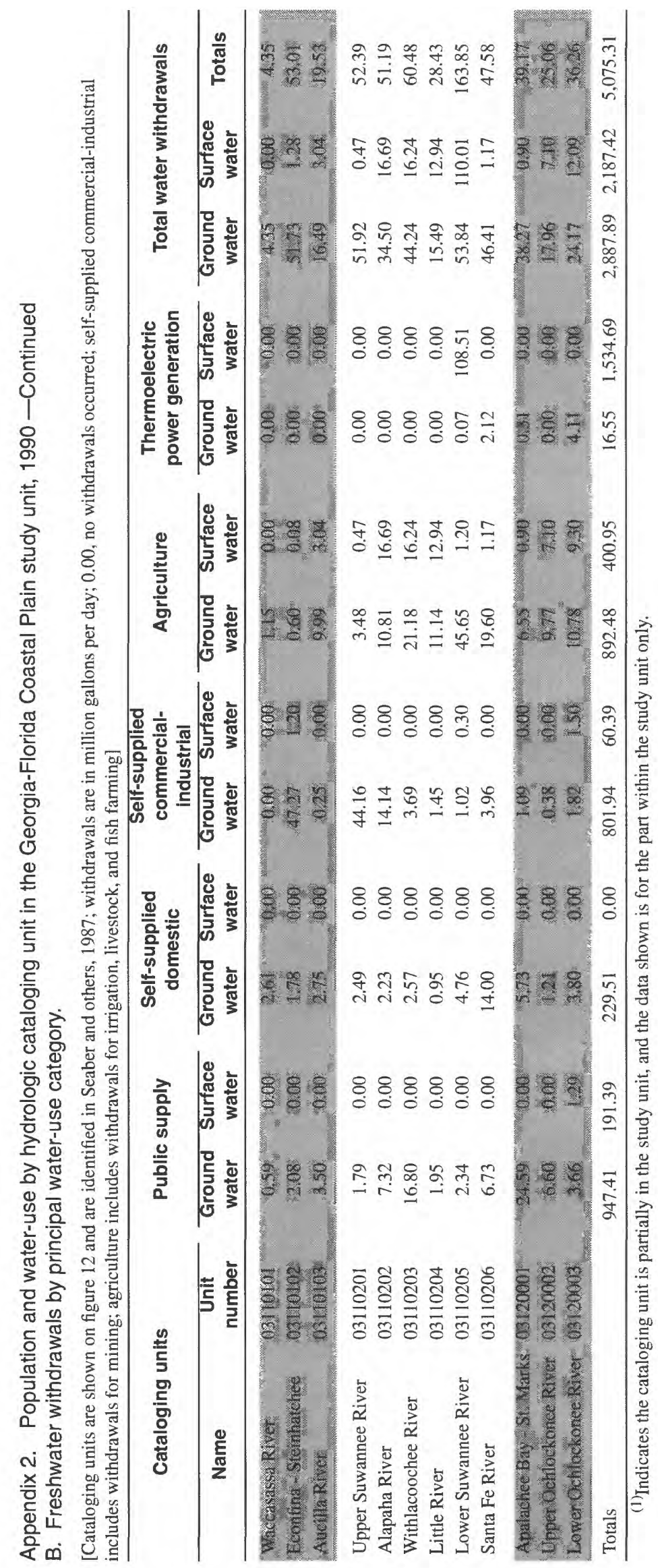


Appendix 3. Domestic wastewater discharge by utility in the Georgia-Florida Coastal Plain study unit, 1990 This appendix is divided into the following sections: A. In Florida. B. In Georgia.

A. Florida.

[Modified from Marella. 1994: capacity and discharge values are in million gallons per day; G. Ground; S. Surface; STP, sewage treatment plant; FDOC, Florida Department of Corrections; Co., County; N/A, data not available; WWTP, wastewater treatment plant; St.. street: N. north: So, south; JSU, Jacksonville Suburban Utilities; NAS, Naval Air Station; S/D, subdivision; W. west; AFB, Air Force Base; W/S, water system; Reg., regional; Ser., service; V., vista; Land., landing; Dist., district; Fla., Florida; MHP, mobile home park]

\begin{tabular}{|c|c|c|c|c|c|c|}
\hline \multirow[b]{2}{*}{ Owner/Facility } & \multirow[b]{2}{*}{ County } & \multirow[b]{2}{*}{ Cataloging unit } & \multicolumn{3}{|c|}{$\begin{array}{l}\text { Facility discharge } \\
\text { information }\end{array}$} & \multirow[b]{2}{*}{$\begin{array}{l}\text { Disposal system method } \\
\text { or receiving water body }\end{array}$} \\
\hline & & & $\begin{array}{l}\text { Design } \\
\text { capacity }\end{array}$ & $\begin{array}{c}1990 \\
\text { dis- } \\
\text { charge }\end{array}$ & $\begin{array}{l}\text { Disposal } \\
\text { source }\end{array}$ & \\
\hline Alachua, city of & Alachua & Santa Fe River & 0.40 & 0.34 & G & Spray field \\
\hline Gainesville Regional STP 1 & Alachua & Oklawaha River & 7.50 & 4.74 & $\mathrm{~S}$ & Sweetwater Creek \\
\hline Gainesville Regional STP 5 & Alachua & Oklawaha River & 10.00 & 7.92 & G & Injection well \\
\hline Newberry, city of & Alachua & Waccasassa River & 0.40 & 0.21 & G & Spray field \\
\hline University of Florida & Alachua & Oklawaha River & 3.10 & 1.44 & $S$ & Lake Alice \\
\hline FDOC: Baker Correctional & Baker & Santa Fe River & 0.19 & 0.16 & G & Percolation pond \\
\hline Macclenny, city of & Baker & St. Marys River & 0.64 & 0.51 & $\mathrm{~S}$ & Overland flow/Turkey Creek \\
\hline Florida State Hospital & Baker & St. Marys River & 0.30 & 0.14 & $S$ & Little St. Marys River \\
\hline Florida State Prison & Bradford & Santa Fe River & 1.30 & 0.98 & $S$ & New River \\
\hline Starke, city of & Bradford & Santa Fe River & 1.20 & 0.97 & $\mathrm{~S}$ & Alligator Crek \\
\hline Barefoot Bay & Brevard & Cape Canaveral Coastal & 0.90 & 0.81 & G & Percolation pond/spray field \\
\hline Brevard Co.: Indian Harbor & Brevard & Cape Canaveral Coastal & 2.50 & 2.18 & G & N/A \\
\hline Brevard Co.: Merritt Island & Brevard & Cape Canaveral Coastal & 6.00 & 2.42 & G & Injection well \\
\hline Brevard Co.: N. Brevard & Brevard & Cape Canaveral Coastal & 1.00 & 0.23 & G & Percolation pond \\
\hline Brevard Co.: Port St. John & Brevard & Cape Canaveral Coastal & 0.25 & 0.16 & G & Percolation pond/spray field \\
\hline \multirow[t]{2}{*}{ Brevard Co.: So. Beaches } & Brevard & Cape Canaveral Coastal & 6.00 & 5.53 & G & Injection well \\
\hline & & & & 0.45 & G & Reuse system \\
\hline Brevard Co.: So. Central & Brevard & Cape Canaveral Coastal & 3.00 & 2.87 & G & Spray field \\
\hline Brevard Co.: Suntree & Brevard & Cape Canaveral Coastal & 0.50 & 0.48 & G & Percolation pond \\
\hline Brevard Co.: So. Patrick & Brevard & Cape Canaveral Coastal & 2.00 & 1.70 & G & Percolation pond \\
\hline Cape Canaveral, city of & Brevard & Cape Canaveral Coastal & 1.80 & 0.90 & G & Percolation pond \\
\hline Cocoa, city of & Brevard & Cape Canaveral Coastal & 4.50 & 2.47 & $S$ & Indian River \\
\hline \multirow[t]{2}{*}{ Cocoa Beach, city of } & Brevard & Cape Canaveral Coastal & 6.00 & 1.54 & $S$ & Banana River \\
\hline & & & & 1.59 & G & Reuse system \\
\hline Kennedy Space Center \#1 & Brevard & Cape Canaveral Coastal & 0.38 & 0.12 & G & Percolation pond \\
\hline Melbourne: D.B. Lee WWTP & Brevard & Cape Canaveral Coastal & 7.50 & 3.70 & G & Injection well \\
\hline \multirow[t]{2}{*}{ Melbourne: Grant St. WWTP } & Brevard & Cape Canaveral Coastal & 5.80 & 2.70 & G & Injection well \\
\hline & & & & 0.18 & G & Reuse system \\
\hline Palm Bay, city of & Brevard & Cape Canaveral Coastal & 0.50 & 0.37 & G & Reuse system \\
\hline Port Malabar & Brevard & Cape Canaveral Coastal & 4.00 & 2.79 & G & Injection well \\
\hline Rockledge, city of & Brevard & Cape Canaveral Coastal & 2.30 & 1.68 & G & Injection well \\
\hline Titusville, city of (N.) & Brevard & Cape Canaveral Coastal & 2.80 & 2.24 & $\mathrm{~S}$ & Indian River \\
\hline Titusville, city of (So.) & Brevard & Cape Canaveral Coastal & 2.00 & 1.59 & $S$ & Indian River \\
\hline \multirow[t]{2}{*}{ U.S. Air Force: Capehart } & Brevard & Cape Canaveral Coastal & 1.00 & 0.59 & $\mathrm{~S}$ & Banana River \\
\hline & & & & 0.15 & G & Reuse system \\
\hline U.S. Air Force: Patrick N. & Brevard & Cape Canaveral Coastal & 1.00 & 0.60 & $\mathrm{~S}$ & Banana River \\
\hline U.S. Air Force: Canaveral & Brevard & Cape Canaveral Coastal & 0.50 & 0.38 & $S$ & Banana River \\
\hline West Melbourne, city of & Brevard & Cape Canaveral Coastal & 1.90 & 1.82 & G & Injection well \\
\hline Beverly Hills Rolling Oaks & Citrus & Withlacoochee River & 1.00 & 0.48 & G & Percolation pond \\
\hline
\end{tabular}


Appendix 3. Domestic wastewater discharge by utility in the Georgia-Florida Coastal Plain study unit, 1990 - Continued This appendix is divided into the following sections: A. In Florida. B. In Georgia.

A. Florida.

[Modified from Marella, 1994: capacity and discharge values are in million gallons per day; G. Ground; S. Surface; STP, sewage treatment plant; FDOC, Florida Department of Corrections; Co., County; N/A, data not available; WWTP, wastewater treatment plant; St., street; N, north; So, south; JSU, Jacksonville Suburban Utilities; NAS, Naval Air Station; S/D, subdivision; W. west; AFB, Air Force Base; W/S, water system; Reg., regional; Ser., service; V., vista; Land., landing; Dist., district; Fla., Florida; MHP, mobile home park]

\begin{tabular}{|c|c|c|c|c|c|c|}
\hline \multirow[b]{2}{*}{ Owner/Facility } & \multirow[b]{2}{*}{ County } & \multirow[b]{2}{*}{ Cataloging unit } & \multicolumn{3}{|c|}{$\begin{array}{l}\text { Facility discharge } \\
\text { information }\end{array}$} & \multirow[b]{2}{*}{$\begin{array}{l}\text { Disposal system method } \\
\text { or receiving water body }\end{array}$} \\
\hline & & & $\begin{array}{l}\text { Design } \\
\text { capacity }\end{array}$ & $\begin{array}{c}1990 \\
\text { dis- } \\
\text { charge }\end{array}$ & $\begin{array}{l}\text { Disposal } \\
\text { source }\end{array}$ & \\
\hline Crystal River, city of & Citrus & Crystal - Pithlachasotte & 0.75 & 0.72 & $\mathrm{~S}$ & Crystal River \\
\hline Inverness, city of & Citrus & Withlacoochee River & 1.50 & 0.58 & G & Spray field \\
\hline Sugar Mill Woods & Citrus & Crystal - Pithlachasotte & 0.50 & 0.25 & G & Spray field \\
\hline Green Cove Springs. city of & Clay & Lower St. Johns River & 1.20 & 0.78 & $S$ & St. Johns River \\
\hline Kingsley: Fleming Island & Clay & Lower St. Johns River & 0.72 & 0.32 & $S$ & St. Johns River \\
\hline Kingsley: Orange Park & Clay & Lower St. Johns River & 4.00 & 3.55 & $\mathrm{~S}$ & St. Johns River \\
\hline Orange Park, town of & Clay & Lower St. Johns River & 2.50 & 1.15 & $S$ & St. Johns River \\
\hline Clay Utility: Ridaught Land. & Clay & Lower St. Johns River & 1.00 & 0.57 & $\mathrm{~S}$ & Little Black Creek \\
\hline U.S. Army: Camp Blanding & Clay & Lower St. Johns River & 0.90 & 0.34 & $S$ & Black Creek \\
\hline Lake City, city of & Columbia & Santa Fe River & 3.00 & 1.69 & G & Spray field \\
\hline Cross City: WWTP \#1 & Dixie & Econfina - Steinhatchee & 0.15 & 0.11 & $\mathrm{~S}$ & Unnamed creek \\
\hline Cross City: WWTP \#2 & Dixie & Econfina - Steinhatchee & 0.25 & 0.15 & $S$ & Unnamed swamp \\
\hline Atlantic Beach, city of & Duval & Lower St. Johns River & 2.00 & 1.20 & $\mathrm{~S}$ & Intercoastal waterway \\
\hline Baldwin, city of & Duval & St. Marys River & 0.20 & 0.13 & $S$ & St. Marys River tributary \\
\hline Beauclerc Utilities & Duval & Lower St. Johns River & 0.78 & 0.48 & $\mathrm{~S}$ & Goodby's Lake \\
\hline Buccaneer STP & Duval & Lower St. Johns River & 1.00 & 0.77 & $S$ & St. Johns River \\
\hline Holiday Harbour & Duval & Lower St. Johns River & 1.20 & 0.79 & $S$ & Hog Pen Creek \\
\hline Jacksonville Beach,city of & Duval & Lower St. Johns River & 3.00 & 2.77 & $\mathrm{~S}$ & Pablo Creek \\
\hline Jacksonville: Arlington & Duval & Lower St. Johns River & 10.00 & 4.72 & $\mathrm{~S}$ & St. Johns River \\
\hline Jacksonville: Buckman St. & Duval & Lower St. Johns River & 52.50 & 30.76 & $\mathrm{~S}$ & St. Johns River \\
\hline Jacksonville: District II & Duval & Lower St. Johns River & 10.00 & 2.70 & $\mathrm{~S}$ & St. Johns River \\
\hline Jacksonville: Mandarin & Duval & Lower St. Johns River & 4.00 & 3.48 & $S$ & St. Johns River \\
\hline Jacksonville: Southwest & Duval & Lower St. Johns River & 10.00 & 5.48 & $\mathrm{~S}$ & St. Johns River \\
\hline JSU: Holly Oaks WWTP & Duval & Lower St. Johns River & 1.00 & 0.42 & $\mathrm{~S}$ & Cow Head Creek \\
\hline JSU: Jacksonville Heights & Duval & Lower St. Johns River & 2.50 & 1.29 & $S$ & Fishing Creek \\
\hline JSU: Monterey STP & Duval & Lower St. Johns River & 3.00 & 2.20 & $S$ & St. Johns River \\
\hline ISU: Royal Lakes STP & Duval & Lower St. Johns River & 2.40 & 1.90 & $\mathrm{~S}$ & Pottsburg Creek \\
\hline JSU: San Jose STP & Duval & Lower St. Johns River & 2.20 & 1.57 & $\mathrm{~S}$ & St. Johns River \\
\hline Neptune Beach, city of & Duval & Lower St. Johns River & 0.75 & 0.86 & $\mathrm{~S}$ & Intercoastal waterway \\
\hline Ortega Utilities: Blanding & Duval & Lower St. Johns River & 0.35 & 0.50 & $\mathrm{~S}$ & Ortega Creek \\
\hline Riverside Plaza & Duval & Lower St. Johns River & N/A & 0.67 & $\mathrm{~S}$ & St. Johns River \\
\hline Southern States: Beacon Hills & Duval & Lower St. Johns River & 1.80 & 0.77 & $\mathrm{~S}$ & St. Johns River \\
\hline Southern States: Woodmere & Duval & Lower St. Johns River & 0.50 & 0.43 & $\mathrm{~S}$ & Fairfield Branch \\
\hline U.S. Navy: Cecil Field & Duval & Lower St. Johns River & 1.20 & 0.62 & $S$ & Rowell Creek/Sal Taylor Creek \\
\hline U.S. Navy: Jacksonville NAS & Duval & Lower St. Johns River & 3.00 & 2.19 & $\mathrm{~S}$ & St. Johns River \\
\hline U.S. Navy: Mayport NAS & Duval & Lower St. Johns River & 1.80 & 1.29 & $\mathrm{~S}$ & St. Johns River \\
\hline Bunnell, city of & Flagler & Lower St. Johns River & 0.30 & 0.22 & $\mathrm{~S}$ & Haw Creek \\
\hline Flagler Beach, city of & Flagler & Daytona - St. Augustine & 1.00 & 0.56 & $\mathrm{~S}$ & Intercoastal waterway \\
\hline Palm Coast Utilities & Flagler & Daytona - St. Augustine & 1.60 & 1.62 & G & Percolation pond/spray field \\
\hline
\end{tabular}


Appendix 3. Domestic wastewater discharge by utility in the Georgia-Florida Coastal Plain study unit, 1990 - Continued This appendix is divided into the following sections: A. In Florida. B. In Georgia.

A. Florida.

[Modified from Marella, 1994; capacity and discharge values are in million gallons per day; G. Ground; S. Surface; STP, sewage treatment plant; FDOC, Florida Department of Corrections; Co., County; N/A, data not available; WWTP, wastewater treatment plant; St., street; N, north; So, south; JSU, Jacksonville Suburban Utilities; NAS, Naval Air Station; S/D, subdivision; W. west; AFB, Air Force Base; W/S, water system; Reg., regional; Ser., service; V., vista; Land., landing; Dist., district; Fla., Florida; MHP, mobile home park]

\begin{tabular}{|c|c|c|c|c|c|c|}
\hline \multirow[b]{2}{*}{ Owner/Facility } & \multirow[b]{2}{*}{ County } & \multirow[b]{2}{*}{ Cataloging unit } & \multicolumn{3}{|c|}{$\begin{array}{c}\text { Facility discharge } \\
\text { information }\end{array}$} & \multirow[b]{2}{*}{$\begin{array}{l}\text { Disposal system method } \\
\text { or receiving water body }\end{array}$} \\
\hline & & & $\begin{array}{l}\text { Design } \\
\text { capacity }\end{array}$ & $\begin{array}{c}1990 \\
\text { dis- } \\
\text { charge }\end{array}$ & $\begin{array}{l}\text { Disposal } \\
\text { source }\end{array}$ & \\
\hline Havana, city of & Gadsden & Lower Ochlockonee River & 0.30 & 0.26 & $\mathrm{~S}$ & Womack Creek/Lake Talquin \\
\hline Quincy, city of & Gadsden & Lower Ochlockonee River & 1.50 & 0.83 & $\mathrm{~S}$ & Quincy Creek \\
\hline Trenton, town of & Gilchrist & Lower Suwannee River & 0.20 & 0.18 & G & Percolation pond \\
\hline Jasper, city of & Hamilton & Lower Suwannee River & 0.40 & 0.49 & S & Bells Creek \\
\hline White Springs, city of & Hamilton & Lower Suwannee River & 0.15 & 0.10 & $\mathrm{~S}$ & Suwannee River \\
\hline Berkeley Manor S/D & Hernando & Crystal - Pithlachasotte & 0.75 & 0.20 & G & Spray field/percolation pond \\
\hline Brookridge S/D & Hernando & Crystal - Pithlachasotte & 0.25 & 0.20 & G & Percolation pond \\
\hline Brooksville: Croom Road & Hernando & Crystal - Pithlachasotte & 0.38 & 0.21 & G & Percolation pond \\
\hline Brooksville: School St. & Hernando & Crystal - Pithlachasotte & 0.84 & 0.52 & G & Percolation pond \\
\hline High Point S/D & Hernando & Withlacoochee River & 0.30 & 0.22 & G & Percolation pond \\
\hline Hill-N-Dale S/D & Hernando & Withlacoochee River & 0.15 & 0.10 & G & Percolation pond \\
\hline Spring Hill Utilities & Hernando & Crystal - Pithlachasotte & 2.00 & 0.84 & G & Spray field/percolation pond \\
\hline W. Hernando: Hernando Beach & Hernando & Crystal - Pithlachasotte & 0.20 & 0.13 & G & Spray field/percolation pond \\
\hline W. Hernando: Weeki Wachee & Hernando & Crystal - Pithlachasotte & 0.25 & 0.12 & G & Percolation pond \\
\hline Apollo Beach. WWTP 1 and 2 & Hillsborough & Tampa Bay & 1.50 & 0.42 & G & Spray field \\
\hline Boyette Springs & Hillsborough & Tampa Bay & 0.13 & 0.10 & G & Drain field \\
\hline Carrolwood S/D & Hillsborough & Tampa Bay & 0.45 & 0.37 & $\mathrm{~S}$ & Canal A/Sweetwater Creek \\
\hline Country Meadows Estates & Hillsborough & Tampa Bay & 0.17 & 0.11 & G & Spray field/percolation pond \\
\hline Groves North & Hillsborough & Tampa Bay & 0.22 & 0.16 & G & Spray field \\
\hline Heather Lakes & Hillsborough & Tampa Bay & 0.10 & 0.10 & G & Percolation pond \\
\hline Hillsborough Co.: Dale Mabry & Hillsborough & Tampa Bay & 6.00 & 5.38 & $\mathrm{~S}$ & Brushy Crek \\
\hline Hillsborough Co.: Falkenburg & Hillsborough & Tampa Bay & 3.00 & 2.89 & $\mathrm{~S}$ & Palm River/Tampa Bypass Canal \\
\hline Hillsborough Co.: Progress & Hillsborough & Tampa Bay & 0.75 & 0.23 & $\mathrm{~S}$ & Archie Creek \\
\hline Hillsborough Co.: River Oaks & Hillsborough & Tampa Bay & 10.00 & 7.06 & $\mathrm{~S}$ & Canal A \\
\hline Hillsborough Co.: South Reg. & Hillsborough & Hillsborough River & 3.00 & 1.21 & G & Spray field \\
\hline Hillsborough Co.: Valrico & Hillsborough & Hillsborough River & 3.00 & 1.21 & $\mathrm{~S}$ & Turkey Crek \\
\hline Pebble Creek & Hillsborough & Hillsborough River & 0.54 & 0.17 & G & Spray field \\
\hline Plant City, city of & Hillsborough & Hillsborough River & 8.00 & 3.34 & $\mathrm{~S}$ & Baker/Mill/Pemberton Creeks \\
\hline Rice Creek Utility & Hillsborough & Tampa Bay & 0.30 & 0.22 & G & Percolation pond \\
\hline Scarecrow Utility: Windemere & Hillsborough & Tampa Bay & 0.26 & 0.12 & $\mathrm{G}$ & Percolation pond \\
\hline Seaboard Utilities & Hillsborough & Alifia River & 0.82 & 0.92 & G & Spray field/percolation pond \\
\hline Summerfield subregional & Hillsborough & Hillsborough River & 0.75 & 0.11 & G & Spray field \\
\hline Tampa: Hookers Point & Hillsborough & Tampa Bay & 70.00 & 52.52 & $\mathrm{~S}$ & Hillsborough Bay \\
\hline Tampa: Suburban & Hillsborough & Hillsborough River & 1.00 & 0.52 & G & Spray field/percolation pond \\
\hline U.S. Air Force: Macdill AFB & Hillsborough & Tampa Bay & 1.20 & 0.80 & $\mathrm{~S}$ & Hillsborough Bay \\
\hline Van Dyke Resource Venture & Hillsborough & Tampa Bay & 1.50 & 0.39 & G & Percolation pond \\
\hline Countryside of Vero Beach & Indian River & Vero Beach Coastal & 0.12 & 0.10 & G & Percolation pond \\
\hline Indian River Co.: Gifford & Indian River & Vero Beach Coastal & 2.00 & 0.41 & $\mathrm{G}$ & Percolation pond/spray field \\
\hline Indain River Co.: V. Royale & Indian River & Vero Beach Coastal & 0.50 & 0.17 & G & Percolation pond \\
\hline
\end{tabular}


Appendix 3. Domestic wastewater discharge by utility in the Georgia-Florida Coastal Plain study unit, 1990 -Continued This appendix is divided into the following sections: A. In Florida. B. In Georgia.

\section{A. Florida.}

[Modified from Marella, 1994; capacity and discharge values are in million gallons per day; G. Ground; S. Surface; STP, sewage treatment plant; FDOC, Florida Department of Corrections; Co., County; N/A, data not available; WWTP, wastewater treatment plant; St., street; N. north; So, south; JSU, Jacksonville Suburban Utilities; NAS, Naval Air Station; S/D, subdivision; W. west; AFB, Air Force Base; W/S, water system; Reg., regional; Ser., service; V., vista; Land., landing; Dist., district; Fla., Florida; MHP, mobile home park]

\begin{tabular}{|c|c|c|c|c|c|c|}
\hline \multirow[b]{2}{*}{ Owner/Facility } & \multirow[b]{2}{*}{ County } & \multirow[b]{2}{*}{ Cataloging unit } & \multicolumn{3}{|c|}{$\begin{array}{l}\text { Facility discharge } \\
\text { information }\end{array}$} & \multirow[b]{2}{*}{$\begin{array}{l}\text { Disposal system method } \\
\text { or receiving water body }\end{array}$} \\
\hline & & & $\begin{array}{l}\text { Design } \\
\text { capacity }\end{array}$ & $\begin{array}{c}1990 \\
\text { dis- } \\
\text { charge }\end{array}$ & $\begin{array}{l}\text { Disposal } \\
\text { source }\end{array}$ & \\
\hline Indian River Co.: W. Region & Indian River & Vero Beach Coastal & 2.00 & 0.43 & $\mathrm{G}$ & Percolation pond/spray field \\
\hline Sebastian Highlands & Indian River & Vero Beach Coastal & 0.30 & 0.10 & G & Percolation pond \\
\hline Vero Beach, city of & Indian River & Vero Beach Coastal & 4.50 & 2.72 & $\mathrm{~S}$ & Indian River \\
\hline Vero Beach Highlands & Indian River & Vero Beach Coastal & 0.45 & 0.28 & G & Percolation pond \\
\hline Monticello, city of & Jefferson & Apalachee Bay - St. Mark & 0.30 & 0.53 & S & Unnamed swamp/wetlands \\
\hline Clermont, city of & Lake & Oklawaha River & 0.95 & 0.72 & $\mathrm{G}$ & Percolation pond \\
\hline Deanza-Mid Florida Lakes & Lake & Oklawaha River & 0.18 & 0.10 & G & Percolation pond \\
\hline Eustis, city of & Lake & Oklawaha River & 1.80 & 1.11 & G & Percolation pond/spray field \\
\hline Leesburg, city of & Lake & Oklawaha River & 3.50 & 2.44 & G & Percolation pond/reuse system \\
\hline Mt. Dora, city of & Lake & Oklawaha River & 1.50 & 0.83 & $\mathrm{G}$ & Spray field/reuse system \\
\hline Orange Blossom Gardens & Lake & Oklawaha River & 0.95 & 0.34 & $\mathrm{G}$ & Reuse system \\
\hline Tavares: Main & Lake & Oklawaha River & 0.75 & 0.55 & G & Percolation pond \\
\hline Tavares: Woodlea Road & Lake & Oklawaha River & 1.00 & 0.31 & G & Percolation pond \\
\hline Umatilla, city of & Lake & Oklawaha River & 0.30 & 0.18 & G & Percolation pond/spray field \\
\hline Tallahassee: Lake Bradford & Leon & Apalachee Bay - St.Marks & 4.50 & 4.19 & $\mathrm{G}$ & Spray field \\
\hline Tallahassee: T.P. Smith & Leon & Apalachee Bay - St.Marks & 20.00 & 11.79 & $\mathrm{G}$ & Reuse system \\
\hline Talquin Electric: Lakewood & Leon & Lower Ochlockonee River & 0.30 & 0.19 & G & Percolation pond \\
\hline Chiefland, town of & Levy & Lower Suwannee River & 0.30 & 0.17 & G & Percolation pond \\
\hline Williston, city of & Levy & Oklawaha River & 0.45 & 0.30 & $\mathrm{G}$ & Percolation pond \\
\hline FDOC: Liberty Correctional & Liberty & Lower Ochlockonee River & 0.20 & 0.11 & G & N/A \\
\hline Madison, city of & Madison & Aucilla River & 0.75 & 0.63 & $\mathrm{~S}$ & Dry Drainage Ditch \\
\hline Belleview, city of & Marion & Withlacoochee River & 0.35 & 0.31 & G & Percolation pond \\
\hline Dunnellon, city of & Marion & Oklawaha River & 0.25 & 0.13 & $\mathrm{~S}$ & Rainbow River \\
\hline FDOC: Marion Correctional & Marion & Oklawaha River & 0.44 & 0.30 & G & Spray field \\
\hline Marion Oaks & Marion & Oklawaha River & 0.20 & 0.11 & G & Percolation pond \\
\hline Oak Run S/D & Marion & Oklawaha River & 0.50 & 0.16 & $\mathrm{G}$ & Percolation pond \\
\hline Ocala: WWTP \#1 & Marion & Oklawaha River & 2.40 & 1.25 & G & Reuse sytem \\
\hline Ocala: WWTP \#2 & Marion & Oklawaha River & 3.50 & 3.03 & G & Spray field \\
\hline On Top of the World W/S & Marion & Oklawaha River & 0.75 & 0.19 & G & Percolation pond \\
\hline Rolling Green & Marion & Oklawaha River & 0.25 & 0.10 & G & Percolation pond \\
\hline Silver Springs Shores & Marion & Oklawaha River & 0.80 & 0.61 & G & Percolation pond/spray field \\
\hline Amelia Island Plantation & Nassau & Nassau River & 0.60 & 0.35 & $\mathrm{G}$ & Spray field/reuse system \\
\hline Callahan, town of & Nassau & Nassau River & 0.30 & 0.16 & $\mathrm{~S}$ & Alligator Creek \\
\hline Fernandina Beach & Nassau & St. Marys River & 1.70 & 1.62 & $\mathrm{~S}$ & Amelia River \\
\hline Hillard, town of & Nassau & St. Marys River & 0.16 & 0.18 & G & Spray field \\
\hline Apopka, city of & Orange & Upper St. Johns River & 4.00 & 1.11 & G & Spray field/reuse system \\
\hline Camino Real STP & Orange & Kissimmee River & 0.35 & 0.26 & G & Percolation pond \\
\hline Fairway MHP & Orange & Upper St. Johns River & 0.15 & 0.13 & G & Percolation pond/reuse system \\
\hline Marriott Hotel STP & Orange & Kissimmee River & 0.45 & 0.22 & G & Reuse system \\
\hline
\end{tabular}


Appendix 3. Domestic wastewater discharge by utility in the Georgia-Florida Coastal Plain study unit, 1990 -Continued This appendix is divided into the following sections: A. In Florida. B. In Georgia.

A. Florida.

[Modified from Marella, 1994; capacity and discharge values are in million gallons per day; G. Ground; S. Surface; STP, sewage treatment plant; FDOC, Florida Department of Corrections; Co., County; N/A, data not available; WWTP, wastewater treatment plant; St., street; N, north; So, south; JSU, Jacksonville Suburban Utilities; NAS, Naval Air Station; S/D, subdivision; W. west; AFB, Air Force Base; W/S, water system; Reg., regional; Ser., service; V., vista; Land., landing; Dist., district; Fla., Florida; MHP, mobile home park]

\begin{tabular}{|c|c|c|c|c|c|c|}
\hline \multirow[b]{2}{*}{ Owner/Facility } & \multirow[b]{2}{*}{ County } & \multirow[b]{2}{*}{ Cataloging unit } & \multicolumn{3}{|c|}{$\begin{array}{l}\text { Facility discharge } \\
\text { information }\end{array}$} & \multirow[b]{2}{*}{$\begin{array}{l}\text { Disposal system method } \\
\text { or receiving water body }\end{array}$} \\
\hline & & & $\begin{array}{l}\text { Design } \\
\text { capacity }\end{array}$ & $\begin{array}{c}1990 \\
\text { dis- } \\
\text { charge }\end{array}$ & $\begin{array}{l}\text { Disposal } \\
\text { source }\end{array}$ & \\
\hline Ocoee, city of & Orange & Oklawaha River & 1.60 & 0.73 & $\mathrm{G}$ & Percolation pond \\
\hline Orange Co.: Cypress Walk & Orange & Kissimmee River & 1.00 & 0.53 & G & Reuse system \\
\hline Orange Co.: Easterly & Orange & Upper St. Johns River & 19.00 & 5.64 & $\mathrm{~S}$ & Wetland/Econlockhatchee River \\
\hline Orange Co.: Meadow Woods & Orange & Kissimmee River & 0.50 & 0.28 & G & Spray field/reuse system \\
\hline Orange Co.: Northwest & Orange & Oklawaha River & 3.00 & 2.16 & G & Percolation pond \\
\hline Orange Co.: Pepper Mill & Orange & Kissimmee River & 1.80 & 0.50 & G & Percolation pond \\
\hline Orange Co.: Sand Lake Road & Orange & Kissimmee River & 30.00 & 12.52 & G & Reuse system \\
\hline Orange Co.: Vistana & Orange & Kissimmee River & 0.33 & 0.22 & G & Percolation pond \\
\hline Orlando: Conserv I & Orange & Upper St. Johns River & 7.50 & 3.63 & G & Percolation pond \\
\hline Orlando: Conserv II & Orange & Upper St. Johns River & 44.00 & 21.34 & G & Reuse system \\
\hline Orlando: Iron Bridge WWTP & Orange & Upper St. Johns River & 20.00 & 13.28 & $S$ & Wetland/Econlockhatchee River \\
\hline Orlando: McLeod Road & Orange & Kissimmee River & 25.00 & 12.50 & G & Reuse system \\
\hline Park Manor STP & Orange & Oklawaha River & 0.35 & 0.26 & G & Percolation pond \\
\hline Reedy Creek Improvement Dist. & Orange & Kissimmee River & 15.00 & 7.40 & G & Percolation pond \\
\hline Rock Springs MHP & Orange & Upper St. Johns River & 0.15 & 0.10 & G & Percolation pond \\
\hline Starlight Ranch MHP & Orange & Upper St. Johns River & 0.12 & 0.13 & G & Percolation pond \\
\hline University of Central Fla. & Orange & Upper St. Johns River & 0.50 & 0.19 & G & Reuse system \\
\hline University Shores \#1 & Orange & Oklawaha River & 0.28 & 0.12 & S & Little Econlockhatchee River \\
\hline University Shores \#2 & Orange & Oklawaha River & 1.00 & 0.51 & G & Percolation pond \\
\hline Winter Garden, city of & Orange & Oklawaha River & 2.00 & 1.08 & G & Percolation pond \\
\hline Winter Park, city of & Orange & Upper St. Johns River & 7.50 & 5.39 & G & Reuse system \\
\hline Buenaventure Lakes STP & Osceola & Kissimmee River & 1.50 & 1.30 & G & Spray field/reuse system \\
\hline Kissimmee Good Samaratin & Osceola & Kissimmee River & 0.21 & 0.14 & G & Spray field/reuse system \\
\hline Kissimmee: Camelot STP & Osceola & Kissimmee River & 3.00 & 0.45 & G & Percolation pond/spray field \\
\hline Kissimmee: Parkway STP & Osceola & Kissimmee River & 1.50 & 0.30 & G & Spray field/reuse system \\
\hline Kissimmee: South Bermuda STP & Osceola & Kissimmee River & 7.00 & 3.76 & G & Percolation pond/spray field \\
\hline Kissimmee: Western STP & Osceola & Kissimmee River & 1.20 & 1.35 & G & Percolation pond \\
\hline Orlando Hyatt House Hotel & Osceola & Kissimmee River & 0.40 & 0.20 & G & Spray field \\
\hline Poinciana Utilities STP \#2 & Osceola & Kissimmee River & 0.50 & 0.49 & G & Spray field \\
\hline Poinciana Utilities STP \#5 & Osceola & Kissimmee River & 0.66 & 0.50 & G & Percolation pond \\
\hline St. Cloud, city of & Osceola & Kissimmee River & 2.20 & 1.29 & G & Spray field \\
\hline Aloha Utility: Aloha Gardens & Pasco & Crystal - Pithlachasotte & 0.85 & 0.38 & G & Percolation pond \\
\hline Aloha Utility: Seven Springs & Pasco & Crystal - Pithlachasotte & 1.20 & 0.55 & G & Percolation pond \\
\hline Dade City, city of & Pasco & Withlacoochee River & 1.50 & 0.74 & $\mathrm{~S}$ & Withlacoochee River \\
\hline Deer Park STP & Pasco & Crystal - Pithlachasotte & 1.20 & 0.63 & G & Percolation pond \\
\hline Forest Hills Utilities & Pasco & Crystal - Pithlachasotte & 0.30 & 0.17 & G & Percolation pond/spray field \\
\hline Jasmine Lakes Ser. Area & Pasco & Crystal - Pithlachasotte & 0.37 & 0.21 & G & Percolation pond \\
\hline Lindrick Ser. Corporation & Pasco & Crystal - Pithlachasotte & 1.00 & 0.49 & $\mathrm{~S}$ & Cross Bayou \\
\hline Mad Hatter: Carpenters Run & Pasco & Hillsborough River & N/A & 0.15 & G & Percolation pond \\
\hline
\end{tabular}


Appendix 3. Domestic wastewater discharge by utility in the Georgia-Florida Coastal Plain study unit, 1990 -Continued This appendix is divided into the following sections: A. In Florida. B. In Georgia.

A. Florida.

[Modified from Marella, 1994; capacity and discharge values are in million gallons per day; G. Ground; S. Surface; STP, sewage treatment plant; FDOC, Florida Department of Corrections; Co., County; N/A, data not available; WWTP, wastewater treatment plant; St., street; N, north; So, south; JSU, Jacksonville Suburban Utilities; NAS, Naval Air Station; S/D, subdivision; W. west; AFB, Air Force Base; W/S, water system; Reg., regional; Ser., service; V., vista; Land., landing; Dist., district; Fla., Florida; MHP, mobile home park]

\begin{tabular}{|c|c|c|c|c|c|c|}
\hline \multirow[b]{2}{*}{ Owner/Facility } & \multirow[b]{2}{*}{ County } & \multirow[b]{2}{*}{ Cataloging unit } & \multicolumn{3}{|c|}{$\begin{array}{l}\text { Facility discharge } \\
\text { information }\end{array}$} & \multirow[b]{2}{*}{$\begin{array}{l}\text { Disposal system method } \\
\text { or receiving water body }\end{array}$} \\
\hline & & & $\begin{array}{l}\text { Design } \\
\text { capacity }\end{array}$ & $\begin{array}{c}1990 \\
\text { dis- } \\
\text { charge }\end{array}$ & $\begin{array}{l}\text { Disposal } \\
\text { source }\end{array}$ & \\
\hline Magnolia Valley & Pasco & Crystal - Pithlachasotte & 0.40 & 0.29 & G & Reuse system \\
\hline New Port Richey, city of & Pasco & Crystal - Pithlachasotte & 4.50 & 3.56 & $S$ & Cross Bayou \\
\hline Palm Terrace STP & Pasco & Hillsborough River & 0.13 & 0.11 & G & Percolation pond \\
\hline Pasco Co.: Hudson & Pasco & Crystal - Pithlachasotte & 3.00 & 1.48 & G & Percolation pond \\
\hline Pasco Co.: Embassy Hills & Pasco & Hillsborough River & 3.50 & 3.03 & G & Percolation pond/spray field \\
\hline Pasco Co.: Land-O-Lakes & Pasco & Hillsborough River & 0.40 & 0.22 & G & Percolation pond/spray field \\
\hline Pasco Co.: River Ridge & Pasco & Crystal - Pithlachasotte & 0.30 & 0.10 & $\mathrm{G}$ & Percolation pond \\
\hline Pasco Co.: Southeast & Pasco & Crystal - Pithlachasotte & 0.56 & 0.15 & G & Percolation pond \\
\hline Pasco Co.: Wesley Chapel & Pasco & Crystal - Pithlachasotte & 0.75 & 0.11 & $\mathrm{G}$ & Reuse system \\
\hline Saddlebrook STP & Pasco & Hillsborough River & 0.25 & 0.20 & G & Percolation pond \\
\hline Sea Pines STP & Pasco & Crystal - Pithlachasotte & N/A & 0.14 & G & Percolation pond \\
\hline Shadow Ridge & Pasco & Hillsborough River & 0.20 & 0.16 & $\mathrm{G}$ & Percolation pond \\
\hline Tampa Downs-Quail Hollow & Pasco & Withlacoochee River & 0.10 & 0.13 & G & Percolation pond \\
\hline Zephyrhills, city of & Pasco & Hillsborough River & 2.20 & 0.96 & G & Spray field \\
\hline \multirow[t]{2}{*}{ Belleair, town of } & Pinellas & Crystal - Pithlachasotte & 0.90 & 0.49 & $\mathrm{G}$ & Spray field \\
\hline & & & & 0.15 & $\mathrm{~S}$ & Clearwater Bay \\
\hline Clearwater: East WWTP & Pinellas & Tampa Bay & 5.00 & 3.60 & S & Tampa Bay \\
\hline Clearwater: Marshall St. & Pinellas & Tampa Bay & 10.00 & 6.40 & $S$ & Stevenson Creek \\
\hline Clearwater: Northeast WWTP & Pinellas & Tampa Bay & 8.00 & 5.21 & G & Reuse system \\
\hline Dunedin, city of & Pinellas & Tampa Bay & 6.00 & 4.05 & $\mathrm{~S}$ & St. Joseph Sound \\
\hline Dyna-Flo Service Company & Pinellas & Tampa Bay & 1.00 & 0.64 & G & N/A \\
\hline \multirow[t]{2}{*}{ Largo, city of } & Pinellas & Tampa Bay & 15.00 & 8.01 & $S$ & Tampa Bay \\
\hline & & & & 2.00 & G & Spray field \\
\hline Oldsmar & Pinellas & Tampa Bay & 2.20 & 1.08 & $\mathrm{~S}$ & Old Tampa Bay \\
\hline On Top of the World STP & Pinellas & Tampa Bay & 0.60 & 0.36 & G & N/A \\
\hline Pinellas Co.: Eastlake & Pinellas & Tampa Bay & 0.40 & 0.29 & G & Reuse system \\
\hline \multirow[t]{2}{*}{ Pinellas Co.: Mckay Creek } & Pinellas & Tampa Bay & 6.00 & 4.30 & $\mathrm{G}$ & Injection well \\
\hline & & & & 0.00 & $S$ & Boca Ciega Bay \\
\hline Pinellas Co.: N. Pinellas & Pinellas & Tampa Bay & 9.00 & 3.59 & G & Reuse system \\
\hline Pinellas Co.: Pine Ridge & Pinellas & Tampa Bay & 0.60 & 0.15 & G & Reuse system \\
\hline \multirow[t]{2}{*}{ Pinellas Co.: So. Cross Bayou } & Pinellas & Tampa Bay & 24.50 & 20.03 & G & Injection well \\
\hline & & & & 0.00 & $\mathrm{~S}$ & Joe's Creek \\
\hline Safety Harbor & Pinellas & Tampa Bay & 0.20 & 0.10 & G & Percolation pond \\
\hline \multirow[t]{2}{*}{ St. Petersburg: A. Whited } & Pinellas & Tampa Bay & 12.40 & 3.64 & G & Injection well \\
\hline & & & & 4.42 & G & Reuse system \\
\hline \multirow[t]{2}{*}{ St. Petersburg: Northeast } & Pinellas & Tampa Bay & 16.00 & 5.71 & G & Injection well \\
\hline & & & & 4.67 & G & Reuse system \\
\hline \multirow[t]{2}{*}{ St. Petersburg: Northwest } & Pinellas & Tampa Bay & 20.00 & 4.46 & G & Injection well \\
\hline & & & & 7.36 & G & Reuse system \\
\hline
\end{tabular}


Appendix 3. Domestic wastewater discharge by utility in the Georgia-Florida Coastal Plain study unit, 1990 -Continued This appendix is divided into the following sections: A. In Florida. B. In Georgia.

\section{A. Florida.}

[Modified from Marella, 1994; capacity and discharge values are in million gallons per day; G. Ground; S. Surface; STP, sewage treatment plant: FDOC. Florida Department of Corrections; Co., County; N/A, data not available; WWTP, wastewater treatment plant; St., street; N, north; So, south; JSU, Jacksonville Suburban Utilities; NAS, Naval Air Station; S/D, subdivision; W. west; AFB, Air Force Base; W/S, water system; Reg., regional; Ser., service; V., vista; Land., landing; Dist., district: Fla., Florida; MHP, mobile home park]

\begin{tabular}{|c|c|c|c|c|c|c|}
\hline \multirow[b]{2}{*}{ Owner/Facility } & \multirow[b]{2}{*}{ County } & \multirow[b]{2}{*}{ Cataloging unit } & \multicolumn{3}{|c|}{$\begin{array}{l}\text { Facility discharge } \\
\text { information }\end{array}$} & \multirow[b]{2}{*}{$\begin{array}{l}\text { Disposal system method } \\
\text { or receiving water body }\end{array}$} \\
\hline & & & $\begin{array}{l}\text { Design } \\
\text { capacity }\end{array}$ & $\begin{array}{c}1990 \\
\text { dis- } \\
\text { charge }\end{array}$ & $\begin{array}{l}\text { Disposal } \\
\text { source }\end{array}$ & \\
\hline \multirow[t]{2}{*}{ St. Petersburg: Southwest } & Pinellas & Tampa Bay & 20.00 & 6.64 & G & Injection well \\
\hline & & & & 4.82 & G & Reuse system \\
\hline Tarpon Lake Village & Pinellas & Tampa Bay & 0.80 & 0.15 & G & N/A \\
\hline \multirow[t]{2}{*}{ Tarpon Springs, city of } & Pinellas & Crystal - Pithlachasotte & 4.00 & 1.00 & S & Anclotte River \\
\hline & & & & 0.45 & G & Reuse system \\
\hline Tarpon Woods STP & Pinellas & Crystal - Pithlachasotte & 0.25 & 0.23 & G & Injection well \\
\hline Aurburndale, city of & Polk & Peace River & 1.40 & 0.96 & $S$ & Lake Lena Run \\
\hline Bartow, city of & Polk & Peace River & 2.70 & 2.40 & G & Reuse system \\
\hline FDOC: Avon Park Correctional & Polk & Kissimmee River & 0.48 & 0.43 & S & Arbuckle Creek \\
\hline FDOC: Polk Correctional & Polk & Peace River & 0.25 & 0.26 & G & Percolation pond \\
\hline Fort Meade, city of & Polk & Peace River & 1.00 & 0.41 & G & Percolation pond \\
\hline Garden Grove: Cypresswood & Polk & Kissimmee River & 0.72 & 0.45 & G & Percolation pond \\
\hline Grenelefe Corporation & Polk & Peace River & 0.30 & 0.32 & $\mathrm{G}$ & Reuse system \\
\hline Haines City, city of & Polk & Peace River & 1.40 & 0.96 & G & Spray field/reuse system \\
\hline Lake Alfred, city of & Polk & Peace River & 0.30 & 0.26 & $\mathrm{~S}$ & Lake Haines \\
\hline Lake Wales, city of & Polk & Peace River & 1.90 & 1.14 & $S$ & Lake Effie \\
\hline Lake Wales Utilities & Polk & Kissimmee River & 0.50 & 0.12 & $S$ & Lake Weopakapka \\
\hline Lakeland: Main WWTP & Polk & Peace River & 10.80 & 8.20 & $S$ & Wetlands \\
\hline Lakeland: Northside STP & Polk & Peace River & 4.00 & 1.58 & G & Percolation pond \\
\hline Mulberry, city of & Polk & Alafia River & 0.50 & 0.31 & S & Alaphia River \\
\hline Poinciana Utilities STP \# 3 & Polk & Kissimmee River & 0.30 & 0.25 & $S$ & Wetlands/Cypress Bayhead \\
\hline Polk Co.: I-4 and US 27 So. & Polk & Peace River & 0.20 & 0.14 & G & Percolation pond \\
\hline Polk Co.: Central Regional & Polk & Peace River & 0.20 & 0.25 & G & Percolation pond \\
\hline Polk Co.: Foxwood Lake & Polk & Peace River & 0.10 & 0.10 & G & Percolation pond \\
\hline Polk Co.: Imperial Lake & Polk & Peace River & 0.90 & 0.66 & G & Percolation pond \\
\hline Polk Co.: Jan Phyl Village & Polk & Peace River & 0.20 & 0.20 & $\mathrm{G}$ & Percolation pond \\
\hline Skyview Utilities & Polk & Peace River & 0.40 & 0.18 & G & Spray field/percolation pond \\
\hline Winter Haven: Lake Conine & Polk & Peace River & 1.70 & 0.81 & $\mathrm{~S}$ & Lake Conine \\
\hline Winter Haven: Wahneta WWTP & Polk & Peace River & 5.00 & 3.05 & $\mathrm{~S}$ & Peace Creek drainage canal \\
\hline Crescent, city of & Putnam & Lower St. Johns River & 0.25 & 0.14 & $\mathrm{~S}$ & Crescent Lake \\
\hline Palatka, city of & Putnam & Lower St. Johns River & 3.00 & 2.27 & $S$ & St. Johns River \\
\hline Anastasia/Mainland W/S & St. Johns & Daytona - St. Augustine & 2.00 & 1.09 & $S$ & Matanzas River \\
\hline Hastings, city of & St. Johns & Lower St. Johns River & 0.10 & 0.11 & $\mathrm{~S}$ & Cracker Creek \\
\hline Ponte Vedra Utilities & St. Johns & Daytona - St. Augustine & 0.50 & 0.28 & G & Spray field \\
\hline Sawgrass Utilities & St. Johns & Lower St. Johns River & 0.70 & 0.33 & G & Spray field \\
\hline St. Augustine: STP \# 1 & St. Johns & Daytona - St. Augustine & 5.00 & 1.56 & $\mathrm{~S}$ & Matanzas River \\
\hline St. Augustine: STP \#2 & St. Johns & Daytona - St. Augustine & 1.50 & 0.44 & $S$ & Matanzas River \\
\hline St. Augustine Shores & St. Johns & Daytona - St. Augustine & 0.50 & 0.26 & G & Spray field \\
\hline St. Johns Ser.: Inlet Beach & St. Johns & Daytona - St. Augustine & 0.50 & 0.23 & G & Spray field \\
\hline
\end{tabular}


Appendix 3. Domestic wastewater discharge by utility in the Georgia-Florida Coastal Plain study unit, 1990 -Continued This appendix is divided into the following sections: A. In Florida. B. In Georgia.

A. Florida.

[Modified from Marella, 1994; capacity and discharge values are in million gallons per day; G. Ground; S. Surface: STP, sewage treatment plant; FDOC, Florida Department of Corrections; Co., County; N/A, data not available; WWTP, wastewater treatment plant; St., street; N, north; So, south; JSU, Jacksonville Suburban Utilities; NAS, Naval Air Station; S/D, subdivision; W. west; AFB, Air Force Base; W/S, water system; Reg., regional; Ser., service; V., vista; Land., landing; Dist., district; Fla., Florida; MHP, mobile home park]

\begin{tabular}{|c|c|c|c|c|c|c|}
\hline \multirow[b]{2}{*}{ Owner/Facility } & \multirow[b]{2}{*}{ County } & \multirow[b]{2}{*}{ Cataloging unit } & \multicolumn{3}{|c|}{$\begin{array}{l}\text { Facility discharge } \\
\text { information }\end{array}$} & \multirow[b]{2}{*}{$\begin{array}{l}\text { Disposal system method } \\
\text { or receiving water body }\end{array}$} \\
\hline & & & $\begin{array}{l}\text { Design } \\
\text { capacity }\end{array}$ & $\begin{array}{c}1990 \\
\text { dis- } \\
\text { charge }\end{array}$ & $\begin{array}{l}\text { Disposal } \\
\text { source }\end{array}$ & \\
\hline St. Johns Ser.: Marsh Land. & St. Johns & Lower St. Johns River & 0.50 & 0.31 & $\vec{G}$ & Spray field \\
\hline St. Johns Ser:: Players Club & St. Johns & Lower St. Johns River & 0.90 & 0.25 & G & Spray field \\
\hline Alfaya Utilities & Seminole & Upper St. Johns River & 2.40 & 0.41 & $\mathrm{G}$ & Percolation pond \\
\hline \multirow[t]{2}{*}{ Altamonte Springs, city of } & Seminole & Upper St. Johns River & 12.50 & 4.68 & $\mathrm{~S}$ & Wekiva River \\
\hline & & & & 0.97 & G & Reuse system \\
\hline Casselberry, city of & Seminole & Upper St. Johns River & 0.64 & 0.47 & G & Reuse system \\
\hline Longwood Utilities & Seminole & Upper St. Johns River & 0.50 & 0.40 & G & Percolation pond \\
\hline Orlando: Iron Bridge WWTP & Seminole & Upper St. Johns River & 40.00 & 8.84 & $\mathrm{~S}$ & Wetlands/Econlockhatchee River \\
\hline Sanford, city of & Seminole & Upper St. Johns River & 6.00 & 4.63 & $\mathrm{~S}$ & Lake Monroe/St. Johns River \\
\hline Sanlando: Wekiva Hunt Club & Seminole & Upper St. Johns River & 2.90 & 1.88 & $\mathrm{~S}$ & Sweetwater Creek/Wekiva River \\
\hline Sanlando: Woodlands/Des Pinar & Seminole & Upper St. Johns River & 0.50 & 0.43 & G & Percolation pond/spray field \\
\hline Seminole Co.: I-4 Industrial & Seminole & Upper St. Johns River & 0.10 & 0.12 & $\mathrm{~S}$ & Smith Canal/St. Johns River \\
\hline Seminole Co.: Greenwood & Seminole & Upper St. Johns River & 3.50 & 1.17 & $\mathrm{G}$ & Percolation pond/reuse system \\
\hline Seminole Co.: Heathrow & Seminole & Upper St. Johns River & 0.20 & 0.10 & G & N/A \\
\hline Weathersfield S/D & Seminole & Upper St. Johns River & 0.36 & 0.23 & $\mathrm{~S}$ & Little Wekiva River \\
\hline Winter Springs: Main WWTP & Seminole & Upper St. Johns River & 1.50 & 0.83 & G & Reuse system \\
\hline Winter Springs: Tuscawilla & Seminole & Upper St. Johns River & 2.20 & 0.72 & G & Reuse system \\
\hline Continental Country Club & Sumter & Withlacoochee River & 0.40 & 0.11 & S & Chitty Chatty Marsh \\
\hline FDOC: Sumter Correctional & Sumter & Withlacoochee River & 0.21 & 0.25 & $G$ & Spray field \\
\hline Wildwood, city of & Sumter & Withlacoochee River & 0.50 & 0.37 & $\mathrm{~S}$ & Wetlands \\
\hline Live Oak, city of & Suwannee & Lower Suwannee River & 0.75 & 0.65 & G & Spray field \\
\hline Perry, city of & Taylor & Econfina - Steinhatchee & 1.20 & 0.79 & $\mathrm{~S}$ & Spring Creek \\
\hline Lake Butler, city of & Union & Santa Fe River & 0.50 & 0.39 & $\mathrm{~S}$ & Silver Run Creek \\
\hline Daytona Beach: Bethune Point & Volusia & Daytona - St. Augustine & 12.00 & 8.78 & $\mathrm{~S}$ & Halifax River \\
\hline Daytona Beach: Westside & Volusia & Daytona - St. Augustine & 10.00 & 4.50 & $S$ & Halifax River \\
\hline Deland: Brandy Trails & Volusia & Upper St. Johns River & 0.63 & 0.10 & $\mathrm{G}$ & Reuse system \\
\hline Deland: Regional & Volusia & Upper St. Johns River & 4.00 & 2.22 & $\mathrm{~S}$ & St. Johns River \\
\hline Deltona Utilities & Volusia & Upper St. Johns River & 0.90 & 0.78 & G & Reuse system \\
\hline Edgewater, city of & Volusia & Cape Canaveral Coastal & 2.25 & 0.55 & $\mathrm{~S}$ & North Indian River \\
\hline Holly Hill, city of & Volusia & Daytona - St. Augustine & 2.40 & 1.30 & $\mathrm{~S}$ & 11 th Street Canal \\
\hline New Smyrna Beach, city of & Volusia & Daytona - St. Augustine & 4.00 & 2.38 & $\mathrm{~S}$ & North Indian River \\
\hline Ormond Beach, city of & Volusia & Daytona - St. Augustine & 6.00 & 2.77 & $\mathbf{S}$ & Halifax River \\
\hline Port Orange, city of & Volusia & Daytona - St. Augustine & 12.00 & 5.28 & $S$ & Rose Bay/Halifax River \\
\hline Sugar Mill STP & Volusia & Daytona - St. Augustine & 0.27 & 0.14 & G & Percolation pond \\
\hline Volusia Co.: Four Townes & Volusia & Upper St. Johns River & 0.60 & 0.29 & $\mathrm{G}$ & Percolation pond \\
\hline Volusia Co.: Spruce Creek & Volusia & Upper St. Johns River & 0.35 & 0.20 & G & Percolation pond \\
\hline
\end{tabular}


Appendix 3. Domestic wastewater discharge by utility in the Georgia-Florida Coastal Plain study unit B. Georgia.

[From the USGS water-use data files, Atlanta; capacity and discharge values are in million gallons per day; S. Surface; G. Ground; WPCP, Water pollution control plant; WWTP, Wastewater treatment plant; STP, Sewage treatment plant: N/A. data not available]

\begin{tabular}{|c|c|c|c|c|c|c|}
\hline \multirow[b]{2}{*}{ Facility/Owner } & \multirow[b]{2}{*}{ County } & \multirow[b]{2}{*}{ Cataloging unit } & \multicolumn{3}{|c|}{ Facility discharge information } & \multirow[b]{2}{*}{$\begin{array}{l}\text { Disposal system method } \\
\text { or receiving water body }\end{array}$} \\
\hline & & & $\begin{array}{l}\text { Permitted } \\
\text { amount }\end{array}$ & $\begin{array}{c}1990 \\
\text { dis- } \\
\text { charge }\end{array}$ & $\begin{array}{l}\text { Disposal } \\
\text { source }\end{array}$ & \\
\hline Pearson, city of & Atkinson & Satilla River & 0.36 & 0.24 & $\mathrm{~S}$ & Little Red Bluff Creek \\
\hline Alma, city of & Bacon & Satilla River & 0.75 & 0.33 & $\mathrm{~S}$ & Hurricane Creek/Satilla River \\
\hline Milledgeville, city of & Baldwin & Lower Oconee River & 7.00 & 4.84 & $S$ & Oconee River \\
\hline Statham, city of & Barrow & Upper Oconee River & 0.15 & 0.05 & $\mathrm{~S}$ & Barber Creek \\
\hline Winder, city of & Barrow & Upper Oconee River & 0.60 & 0.47 & $S$ & Marburg Creek \\
\hline Fitzgerald, city of & Ben Hill & Alapaha River & 6.00 & 3.09 & $S$ & Turkey Creek \\
\hline Alapaha, town of & Berrien & Alapaha River & 0.10 & 0.03 & $\mathrm{~S}$ & Alapaha River \\
\hline Nashville, city of & Berrien & Withlacoochee River & 0.63 & 0.23 & $\mathrm{~S}$ & Reedy Creek \\
\hline Ray City, city of & Berrien & Withlacoochee River & 0.10 & 0.03 & $\mathrm{~S}$ & Cat Creek \\
\hline \multicolumn{7}{|l|}{$\begin{array}{l}\text { Macon-Bibb County Water and } \\
\text { Sewer }\end{array}$} \\
\hline Rocky Creek WPCP & Bibb & Upper Ocmulgee River & 21.00 & 14.79 & $\mathrm{~S}$ & Rocky Creek \\
\hline L.B. Wilson Airport WPCP & Bibb & Upper Ocmulgee River & 0.70 & 0.37 & $S$ & Echeconne Creek \\
\hline Lower Popular Street WPCP & Bibb & Upper Ocmulgee River & 18.00 & 12.11 & $\mathrm{~S}$ & Ocmulgee River \\
\hline Cochran, city of & Bleckley & Lower Ocmulgee River & 0.60 & 0.39 & $S$ & Jordan Creek \\
\hline Nahunta, city of & Brantley & Satilla River & 0.12 & $0.00(1)$ & $\mathrm{S}$ & Buffalo Creek \\
\hline Pembroke, city of & Bryan & Canoochee Creek & 0.15 & 0.10 & $S$ & Mill Creek \\
\hline Richmond Hill, city of & Bryan & Lower Ogeechee River & 0.50 & 0.55 & S & Ogeechee River \\
\hline Statesboro, city of & Bulloch & Canoochee Creek & 5.00 & 4.02 & $\mathrm{~S}$ & Little Lotts Creek \\
\hline Midville, city of & Burke & Upper Ogeechee River & 0.17 & $0.00(1)$ & $S$ & Ogeechee River \\
\hline \multicolumn{7}{|l|}{ Jackson, city of } \\
\hline Northside WPCP & Butts & Upper Ocmulgee River & 0.14 & 0.13 & $\mathrm{~S}$ & Yellow Water Creek \\
\hline Southside WPCP & Butts & Upper Ocmulgee River & 0.04 & 0.28 & $S$ & Town Branch Tributary \\
\hline Yellow Water Creek WWTP & Butts & Upper Ocmulgee River & 0.20 & 0.22 & $\mathrm{~s}$ & Yellow Water Creek \\
\hline Kingsland, city of & Camden & St. Marys River & 1.60 & 1.15 & $S$ & Little Catfish Creek \\
\hline St. Marys, city of & Camden & St. Marys River & 0.70 & $0.26(2)$ & $S$ & St. Marys River \\
\hline Woodbine, city of & Camden & Satilla River & 0.37 & 0.15 & $S$ & Satilla River \\
\hline Folkston, city of & Charlton & St. Marys River & 0.28 & 0.22 & $\mathrm{~S}$ & Clay Branch \\
\hline \multicolumn{7}{|l|}{ Savannah, city of } \\
\hline Wilshire/Windsor WPCP & Chatham & Ogeechee Coastal & 4.50 & 2.66 & $\mathrm{~S}$ & Vernon River \\
\hline Gateway/Georgetown WWTP & Chatham & Ogeechee Coastal & 0.19 & 0.06 & $\mathrm{~S}$ & Ogeechee River \\
\hline Larchmont WPCP & Chatham & Ogeechee Coastal & N/A & N/A & $S$ & N/A \\
\hline Skidway Island Utilities & Chatham & Ogeechee Coastal & N/A & N/A & S & N/A \\
\hline \multicolumn{7}{|l|}{ Athens, city of } \\
\hline North Oconee WPCP & Clarke & Upper Oconee River & 10.72 & 6.53 & $S$ & North Oconee River \\
\hline Mid Oconee WPCP & Clarke & Upper Oconee River & 4.00 & 3.58 & $S$ & Middle Oconee River \\
\hline Cedar Creek WPCP & Clarke & Upper Oconee River & 2.00 & 0.61 & $S$ & Oconee River \\
\hline \multicolumn{7}{|l|}{ Clayton County Water Authority } \\
\hline Northeast WPCP & Clayton & Upper Ocmulgee River & 4.00 & 2.78 & $S$ & Panther Creek \\
\hline W.B. Casey WPCP & Clayton & Upper Ocmulgee River & 15.00 & 10.40 & G & Spray field \\
\hline R.E. Jackson WPCP & Clayton & Upper Ocmulgee River & 4.50 & 2.95 & G & Spray field \\
\hline E.L. Huie WPCP & Clayton & Upper Ocmulgee River & 15.00 & 13.98 & G & Spray field \\
\hline Homerville, city of & Clinch & Upper Suwannee River & 0.50 & 0.67 & $\mathrm{~S}$ & Gallows Branch \\
\hline
\end{tabular}


Appendix 3. Domestic wastewater discharge by utility in the Georgia-Florida Coastal Plain study unit - Continued B. Georgia.

[From the USGS water-use data files, Atlanta; capacity and discharge values are in million gallons per day; S. Surface; G. Ground; WPCP, Water pollution control plant; WWTP, Wastewater treatment plant: STP, Sewage treatment plant; N/A, data not available]

\begin{tabular}{|c|c|c|c|c|c|c|}
\hline \multirow[b]{2}{*}{ Facility/Owner } & \multirow[b]{2}{*}{ County } & \multirow[b]{2}{*}{ Cataloging unit } & \multicolumn{3}{|c|}{ Facility discharge information } & \multirow[b]{2}{*}{$\begin{array}{l}\text { Disposal system method } \\
\text { or receiving water body }\end{array}$} \\
\hline & & & $\begin{array}{l}\text { Permitted } \\
\text { amount }\end{array}$ & $\begin{array}{c}1990 \\
\text { dis- } \\
\text { charge }\end{array}$ & $\begin{array}{l}\text { Disposal } \\
\text { source }\end{array}$ & \\
\hline Doerun, city of & Colquitt & Upper Ochlockonee River & 0.15 & 0.04 & $\mathrm{~S}$ & Bridge Creek \\
\hline \multicolumn{7}{|l|}{ Moultrie, city of } \\
\hline Moultrie main WPCP & Colquitt & Upper Ochlockonee River & 4.00 & 2.69 & $S$ & Ocklocknee River \\
\hline Spence Field WPCP & Colquitt & Upper Ochlockonee River & 0.20 & 0.09 & $\mathrm{~S}$ & Little Indian Creek \\
\hline Norman Park, town of & Colquitt & Little River & 0.20 & 0.09 & $S$ & Reddy Creek \\
\hline Adel, city of & Cook & Withlacoochee River & 0.95 & 1.43 & $S$ & Bear Creek \\
\hline Lenox, town of & Cook & Withlacoochee River & 0.17 & 0.04 & $\mathrm{~S}$ & Little River \\
\hline Sparks. town of & Cook & Withlacoochee River & 0.23 & 0.11 & $S$ & Bear Creek \\
\hline \multicolumn{7}{|l|}{ Atlanta, city of } \\
\hline Entrenchment Creek WPCP (3) & Dekalb & Upper Ocmulgee River & N/A & (4) & $\mathrm{S}$ & Entrenchment Creek \\
\hline \multicolumn{7}{|l|}{ DeKalb County Water System } \\
\hline Pole Bridge Creek WPCP & DeKalb & Upper Ocmulgee River & 5.00 & 5.16 & $S$ & South River \\
\hline Snapfinger Creek WPCP & DeKalb & Upper Ocmulgee River & 36.00 & 24.45 & $S$ & South River \\
\hline Chester, town of & Dodge & Little Ocmulgee River & 0.10 & 0.13 & $S$ & Flat Creek \\
\hline \multicolumn{7}{|l|}{ Eastman, city of } \\
\hline Roach Branch WPCP & Dodge & Little Ocmulgee River & 0.90 & 0.46 & $S$ & Roach Branch \\
\hline South WPCP & Dodge & Lower Ocmulgee River & 0.90 & 0.32 & $S$ & Sugar Creek \\
\hline Swainsboro, town of & Emanuel & Ohoopee River & 3.00 & 1.26 & $S$ & Crooked Creek Tributary \\
\hline Twin City, city of & Emanuel & Canoochee Creek & 0.20 & 0.12 & $S$ & Thick Creek \\
\hline Gibson, city of & Glascock & Upper Ogeechee River & 0.21 & 0.04 & $S$ & Rocky Comfort Creek \\
\hline Brunswick, city of & Glynn & Cumberland - St. Simons & 13.50 & 5.78 & $\mathrm{~S}$ & Academy Creek \\
\hline Jekyll Island Water System & Glynn & Cumberland - St. Simons & 1.00 & 0.55 & $S$ & Jekyll River \\
\hline St. Simons Island Water & Glynn & Cumberland - St. Simons & 2.50 & 1.77 & $\mathrm{~S}$ & Dunbar Creek Tributary \\
\hline Cairo, city of & Grady & Upper Ochlockonee River & 2.00 & 0.95 & $S$ & Parkers Mill Creek \\
\hline \multicolumn{7}{|l|}{ Greensboro, city of } \\
\hline North WPCP & Greene & Upper Oconee River & 0.10 & 0.05 & $S$ & Richland Creek \\
\hline South WPCP & Greene & Upper Oconee River & 0.45 & 0.27 & $S$ & Town Creek \\
\hline Union Point, city of & Greene & Upper Ogeechee River & 0.45 & 0.31 & $\mathrm{~S}$ & North Fork Ogeechee River \\
\hline \multicolumn{7}{|l|}{$\begin{array}{l}\text { Gwinnett County Water and } \\
\text { Sewer }\end{array}$} \\
\hline $\begin{array}{l}\text { Beaver Run-Sweetwater } \\
\text { WPCP }\end{array}$ & Gwinnett & Upper Ocmulgee River & 4.50 & 3.83 & $\mathrm{~S}$ & Sweetwater Creek \\
\hline Big Haynes Creek WPCP & Gwinnett & Upper Ocmulgee River & 0.50 & 0.34 & $S$ & Big Haynes Creek \\
\hline Camp Creek WPCP & Gwinnett & Upper Ocmulgee River & 0.06 & 0.02 & $S$ & Hale Creek \\
\hline Castle Wood WPCP & Gwinnett & Upper Ocmulgee River & 0.07 & $0.00(1)$ & $\mathrm{S}$ & Yellow River Tributary \\
\hline Jacks Creek WPCP & Gwinnett & Upper Ocmulgee River & 1.00 & 0.91 & $\mathrm{~S}$ & Jacks Creek \\
\hline Jackson Creek WPCP & Gwinnett & Upper Ocmulgee River & 3.00 & 2.63 & $S$ & Jackson Creek Tributary \\
\hline No Business Creek WPCP & Gwinnett & Upper Ocmulgee River & 1.00 & 0.88 & $\mathrm{~S}$ & No Business Creek \\
\hline Yellow River WPCP & Gwinnett & Upper Ocmulgee River & 8.00 & 6.30 & $\mathrm{~S}$ & Yellow River \\
\hline Sparta, city of & Hancock & Lower Oconee River & 0.08 & 0.09 & $S$ & Buffalo Creek Tributary \\
\hline \multicolumn{7}{|l|}{ Henry County Water Auth. } \\
\hline Camp Creek WPCP & Henry & Upper Ocmulgee River & 1.50 & 0.74 & $\mathrm{~S}$ & Camp Creek \\
\hline Hudson Bridge Road WPCP & Henry & Upper Ocmulgee River & 0.40 & 0.12 & $\mathrm{~S}$ & Walnut Creek Tributary \\
\hline Meadow Creek WPCP & Henry & Upper Ocmulgee River & 0.11 & $0.00(1)$ & $\mathrm{S}$ & Kalves Creek/South River \\
\hline
\end{tabular}


Appendix 3. Domestic wastewater discharge by utility in the Georgia-Florida Coastal Plain study unit —Continued B. Georgia.

[From the USGS water-use data files, Atlanta; capacity and discharge values are in million gallons per day; S. Surface; G. Ground; WPCP, Water pollution control plant; WWTP, Wastewater treatment plant; STP, Sewage treatment plant; N/A, data not available]

\begin{tabular}{|c|c|c|c|c|c|c|}
\hline \multirow[b]{2}{*}{ Facility/Owner } & \multirow[b]{2}{*}{ County } & \multirow[b]{2}{*}{ Cataloging unit } & \multicolumn{3}{|c|}{ Facility discharge information } & \multirow[b]{2}{*}{$\begin{array}{l}\text { Disposal system method } \\
\text { or receiving water body }\end{array}$} \\
\hline & & & $\begin{array}{l}\text { Permitted } \\
\text { amount }\end{array}$ & $\begin{array}{c}1990 \\
\text { dis- } \\
\text { charge }\end{array}$ & $\begin{array}{l}\text { Disposal } \\
\text { source }\end{array}$ & \\
\hline Panola Woods WPCP & Henry & Upper Ocmulgee River & 0.12 & 0.10 & $\mathrm{~S}$ & Clark Creek Tributary \\
\hline Skyland WPCP & Henry & Upper Ocmulgee River & 0.20 & 0.11 & $\mathrm{~S}$ & Bear Creek Tributary \\
\hline Locust Grove, city of (East) & Henry & Upper Ocmulgee River & 0.05 & 0.03 & $\mathrm{~S}$ & Wolf Creek/Tussaha Creek \\
\hline Locust Grove, city of (West) & Henry & Upper Ocmulgee River & 0.05 & 0.03 & $\mathrm{~S}$ & Indian Creek Tributary \\
\hline \multicolumn{7}{|l|}{ McDonough, city of } \\
\hline McDonough Main WPCP & Henry & Upper Ocmulgee River & 0.11 & $0.00(1)$ & $\mathrm{S}$ & Tussaham Creek Tributary \\
\hline Camp Creek WPCP & Henry & Upper Ocmulgee River & 0.50 & 0.36 & $\mathrm{~S}$ & Walnut Creek Tributary \\
\hline Stockbridge, city of & Henry & Upper Ocmulgee River & 0.50 & 0.33 & $\mathrm{~S}$ & Brush Creek \\
\hline Perry, city of & Houston & Lower Ocmulgee River & 3.00 & 1.76 & $\mathrm{~S}$ & Big Indian Creek \\
\hline \multicolumn{7}{|l|}{ Warner Robins, city of } \\
\hline Sandy Run WPCP & Houston & Lower Ocmulgee River & 6.00 & 4.31 & $\mathrm{~S}$ & Sandy Run Creek \\
\hline Horse Creek WPCP & Houston & Lower Ocmulgee River & 3.00 & 1.96 & $\mathrm{~S}$ & Horse Creek Tributary \\
\hline Maysville, city of & Jackson & Upper Oconee River & N/A & 0.04 & $\mathrm{~S}$ & Buckhead Creek \\
\hline Commerce, city of & Jackson & Upper Oconee River & N/A & 0.73 & $\mathrm{~S}$ & North Oconee River \\
\hline Hoschton, city of & Jackson & Upper Oconee River & 0.10 & 0.03 & $\mathrm{~S}$ & Middle Oconee Tributary \\
\hline Jefferson, city of & Jackson & Upper Oconee River & N/A & 0.29 & $\mathrm{~S}$ & Big Curry Creek \\
\hline \multicolumn{7}{|l|}{ Monticello, city of } \\
\hline Pearson Creek Pond & Jasper & Upper Oconee River & 0.17 & 0.08 & $\mathrm{~S}$ & Pearson Creek \\
\hline White Oak Creek Pond & Jasper & Upper Oconee River & 0.11 & 0.06 & $\mathrm{~S}$ & White Oak Creek \\
\hline \multicolumn{7}{|l|}{ Hazelhurst, city of } \\
\hline Pond 1 & Jeff Davis & Lower Ocmulgee River & 0.64 & 0.24 & $\mathrm{~S}$ & Gully Creek \\
\hline Pond 2 & Jeff Davis & Lower Ocmulgee River & 0.24 & 0.22 & $\mathrm{~S}$ & Gully Creek \\
\hline Hazelhurst & Jeff Davis & Lower Ocmulgee River & 1.50 & 0.41 & $\mathrm{~S}$ & Big Satilla River \\
\hline \multicolumn{7}{|l|}{ Louisville, city of } \\
\hline Pond 1 & Jefferson & Upper Ogeechee River & 0.56 & 0.24 & $\mathrm{~S}$ & Ogeechee River \\
\hline Pond 2 & Jefferson & Upper Ogeechee River & 0.06 & 0.02 & $\mathrm{~S}$ & Rocky Comfort Creek \\
\hline Wadley, city of & Jefferson & Upper Ogeechee River & 0.21 & 0.08 & $\mathrm{~S}$ & Williamson Swamp Creek \\
\hline Millen, city of & Jenkins & Upper Ogeechee River & 0.45 & 0.43 & $\mathrm{~S}$ & Buckhead Creek \\
\hline Wrightsville, city of & Johnson & Ohoopee River & 0.75 & 0.36 & $\mathrm{~S}$ & Big Cedar Creek \\
\hline Gray, city of & Jones & Lower Oconee River & 0.40 & 0.16 & $\mathrm{~S}$ & Wolf Creek Tributary \\
\hline Barnesville, city of & Lamar & Upper Ocmulgee River & 1.20 & 0.63 & $S$ & Tobesofkee Creek \\
\hline Lakeland, city of & Lanier & Alapaha River & 0.20 & 0.18 & $\mathrm{~S}$ & Big Creek \\
\hline Cadwell, town of & Laurens & Little Ocmulgee River & 0.05 & 0.04 & $\mathrm{~S}$ & Big Creek \\
\hline Dublin, city of & Laurens & Lower Oconee River & 4.00 & 2.89 & $\mathrm{~S}$ & Oconee River \\
\hline Dudley, city of & Laurens & Lower Oconee River & 0.12 & 0.05 & $\mathrm{~S}$ & Turkey Creek Tributary \\
\hline Ludowici, city of & Long & Altamaha River & 0.24 & 0.02 & $\mathrm{~S}$ & Jones Creek Tributary \\
\hline Hahira, city of & Lowndes & Little River & 0.13 & 0.26 & $\mathrm{~S}$ & Franks Creek \\
\hline \multicolumn{7}{|l|}{ Lowndes County Water System } \\
\hline Twin Lakes WPCP & Lowndes & Alapaha River & 0.15 & 0.10 & $\mathrm{~S}$ & Caney Branch \\
\hline Foxboro WPCP & Lowndes & Withlachoochee River & 0.15 & 0.05 & $S$ & Withlachoochee River Tributary \\
\hline \multicolumn{7}{|l|}{ Valdosta, city of } \\
\hline Mud Creek WPCP & Lowndes & Alapaha River & 3.22 & 1.53 & $\mathrm{~S}$ & Mud Creek Tributary \\
\hline Withlacoochee WPCP & Lowndes & Withlachoochee River & 12.00 & 5.17 & S & Withlachoochee River \\
\hline
\end{tabular}


Appendix 3. Domestic wastewater discharge by utility in the Georgia-Florida Coastal Plain study unit —Continued B. Georgia.

[From the USGS water-use data files, Atlanta; capacity and discharge values are in million gallons per day; S. Surface; G. Ground; WPCP, Water pollution control plant; WWTP. Wastewater treatment plant; STP, Sewage treatment plant; N/A, data not available]

\begin{tabular}{|c|c|c|c|c|c|c|}
\hline \multirow[b]{2}{*}{ Facility/Owner } & \multirow[b]{2}{*}{ County } & \multirow[b]{2}{*}{ Cataloging unit } & \multicolumn{3}{|c|}{ Facility discharge information } & \multirow[b]{2}{*}{$\begin{array}{l}\text { Disposal system method } \\
\text { or receiving water body }\end{array}$} \\
\hline & & & $\begin{array}{l}\text { Permitted } \\
\text { amount }\end{array}$ & $\begin{array}{c}1990 \\
\text { dis- } \\
\text { charge }\end{array}$ & $\begin{array}{l}\text { Disposal } \\
\text { source }\end{array}$ & \\
\hline Darien, city of & McIntosh & Ogeechee Coastal & 0.60 & 0.23 & $\mathrm{~S}$ & Cathead Creek \\
\hline Pelham, city of & Mitchell & Upper Ochlockonee River & 0.75 & 0.76 & $S$ & Big Creek \\
\hline \multicolumn{7}{|l|}{ Forsyth, city of } \\
\hline Northeast WPCP & Monroe & Upper Ocmulgee River & 0.75 & 0.40 & $\mathrm{~S}$ & Town Creek Tributary \\
\hline South WPCP & Monroe & Upper Ocmulgee River & 0.60 & 0.28 & $\mathrm{~S}$ & Mill Branch Tributary \\
\hline Ailey, town of & Montgomery & Lower Oconee River & 0.08 & 0.03 & $\mathrm{~S}$ & Firat Creek \\
\hline Mt. Vernon, city of & Montgomery & Lower Oconee River & 0.27 & 0.18 & $\mathrm{~S}$ & Limestone Creek \\
\hline \multicolumn{7}{|l|}{ Madison, city of } \\
\hline Northside WPCP & Morgan & Upper Oconee River & 0.14 & 0.09 & $\mathrm{~S}$ & Mill Branch Tributary \\
\hline Southside WPCP & Morgan & Upper Oconee River & 0.66 & 0.49 & $S$ & Little Sugar Creek \\
\hline Rutledge, city of & Morgan & Upper Oconee River & 0.05 & 0.03 & $S$ & Big Indian Creek \\
\hline Covington, city of & Newton & Upper Ocmulgee River & 4.80 & $2.99(5)$ & $\mathrm{G}$ & Spray field \\
\hline Byron, city of & Peach & Lower Ocmulgee River & 0.44 & 0.30 & $S$ & Echeconnee Creek \\
\hline Fort Valley, city of & Peach & Lower Ocmulgee River & 2.20 & 0.09 & $\mathrm{~S}$ & Bay Creek \\
\hline \multicolumn{7}{|l|}{ Hawkinsville, city of } \\
\hline Hawkinsville Main WPCP & Pulaski & Lower Ocmulgee River & 1.30 & 1.16 & $\mathrm{~S}$ & Ocmulgee River \\
\hline Hawkinsville North WPCP & Pulaski & Lower Ocmulgee River & 1.00 & $0.00(1)$ & $\mathrm{S}$ & Ocmulgee River \\
\hline \multicolumn{7}{|l|}{ Eatonton, city of } \\
\hline Eatonton East WPCP & Putnam & Upper Oconee River & 0.28 & 0.32 & $\mathrm{~S}$ & Grady Creek Tributary \\
\hline Eatonton West WPCP & Putnam & Upper Oconee River & 0.39 & 0.29 & $S$ & Root Creek Tributary \\
\hline \multicolumn{7}{|l|}{ Conyers, city of } \\
\hline Almand Branch WPCP & Rockdale & Upper Ocmulgee River & 1.25 & 1.11 & $S$ & Almand Branch \\
\hline Honey Creek WPCP & Rockdale & Upper Ocmulgee River & 0.30 & 0.25 & $\mathrm{~S}$ & McLain Branch Tributary \\
\hline Lakeridge Estates WPCP & Rockdale & Upper Ocmulgee River & 0.09 & 0.06 & $S$ & Almand Branch/Snapping Creek \\
\hline Quiggs Branch WPCP & Rockdale & Upper Ocmulgee River & 2.00 & 1.52 & $\mathrm{~S}$ & Quiggs Branch \\
\hline Scott Creek WPCP & Rockdale & Upper Ocmulgee River & 0.30 & 0.08 & $\mathrm{~S}$ & Scott Creek Tributary \\
\hline Stanton Woods WPCP & Rockdale & Upper Ocmulgee River & 0.15 & 0.07 & $\mathrm{~S}$ & Almand Branch/Snapping Creek \\
\hline Atlanta suburbia WPCP & Rockdale & Upper Ocmulgee River & 0.45 & 0.21 & $\mathrm{~S}$ & Snapping Shoals Creek \\
\hline Newington, town of & Screven & Lower Ogeechee River & 0.04 & 0.02 & $\mathrm{~S}$ & Ogeechee Creek \\
\hline \multicolumn{7}{|l|}{ Griffin, city of } \\
\hline Griffin Shoal Creek STP & Spalding & Upper Ocmulgee River & 1.50 & 1.12 & $\mathrm{~S}$ & Shoal Creek \\
\hline Crawfordville, city of & Taliaferro & Upper Ogeechee River & 0.05 & 0.01 & $\mathrm{~S}$ & North Fork Ogeechee River \\
\hline Collins, city of & Tattnall & Ohoopee River & 0.06 & 0.05 & $\mathrm{~S}$ & Cypress Flat Creek \\
\hline Glennville, city of & Tattnall & Altamaha River & 0.88 & 0.48 & $\mathrm{~S}$ & Brick Yard Branch \\
\hline Reidsville, city of & Tattnall & Ohoopee River & 0.18 & 0.12 & $\mathrm{~S}$ & Brazells Creek \\
\hline Helena, city of & Telfair & Little Ocmulgee River & 0.20 & 0.07 & $\mathrm{~s}$ & Little Ocmulgee River \\
\hline Lumber City, city of & Telfair & Little Ocmulgee River & 0.22 & 0.28 & $\mathrm{~S}$ & Ocmulgee River \\
\hline \multicolumn{7}{|l|}{ McRae, city of } \\
\hline Sugar Creek WPCP & Telfair & Little Ocmulgee River & 0.60 & 0.36 & $S$ & Sugar Creek \\
\hline Gum Swamp WPCP & Telfair & Little Ocmulgee River & 0.20 & 0.12 & $\mathrm{~S}$ & Gum Swamp Creek \\
\hline Scotland, city of & Telfair & Little Ocmulgee River & 0.18 & 0.01 & $\mathrm{~S}$ & Little Ocmulgee River \\
\hline Boston, city of & Thomas & Aucilla River & 0.21 & 0.14 & $\mathrm{~S}$ & Aucilla Creek \\
\hline Meigs, city of & Thomas & Upper Ochlockonee River & 0.15 & 0.14 & $\mathrm{~S}$ & Ochlocknee River Tributary \\
\hline
\end{tabular}


Appendix 3. Domestic wastewater discharge by utility in the Georgia-Florida Coastal Plain study unit - Continued B. Georgia.

[From the USGS water-use data files, Atlanta; capacity and discharge values are in million gallons per day; S. Surface; G. Ground; WPCP, Water pollution control plant; WWTP, Wastewater treatment plant; STP, Sewage treatment plant; N/A, data not available]

\begin{tabular}{|c|c|c|c|c|c|c|}
\hline \multirow[b]{2}{*}{ Facility/Owner } & \multirow[b]{2}{*}{ County } & \multirow[b]{2}{*}{ Cataloging unit } & \multicolumn{3}{|c|}{ Facility discharge information } & \multirow[b]{2}{*}{$\begin{array}{l}\text { Disposal system method } \\
\text { or receiving water body }\end{array}$} \\
\hline & & & $\begin{array}{l}\text { Permitted } \\
\text { amount }\end{array}$ & $\begin{array}{c}1990 \\
\text { dis- } \\
\text { charge }\end{array}$ & $\begin{array}{l}\text { Disposal } \\
\text { source }\end{array}$ & \\
\hline Ochlocknee, town of & Thomas & Upper Ochlockonee River & 0.01 & $0.00(1)$ & $\mathrm{S}$ & Ochlocknee River Tributary \\
\hline Thomasville, city of & Thomas & Aucilla River & 6.50 & 3.19 & $S$ & Oquina Creek \\
\hline Tifton, city of & Tift & Withlacoochee River & 8.00 & 4.34 & $\mathrm{~S}$ & New River \\
\hline Ty Ty, town of & Tift & Little River & 0.07 & 0.03 & $S$ & Ty Ty Creek \\
\hline \multicolumn{7}{|l|}{ Lyons, city of } \\
\hline Lyons North WPCP & Toombs & Ohoopee River & 0.48 & 0.21 & $\mathrm{~S}$ & Swift Creek \\
\hline Lyons Swift Creek WPCP & Toombs & Ohoopee River & 0.55 & 0.26 & $\mathrm{~S}$ & Swift Creek Tributary \\
\hline Santa Claus, city of & Toombs & Ohoopee River & 0.01 & 0.01 & $\mathrm{~S}$ & Rocky Creek Tributary \\
\hline Vidalia, city of & Toombs & Ohoopee River & 1.88 & 1.77 & $\mathrm{~S}$ & Swift Creek \\
\hline Soperton, city of & Treutlen & Lower Oconee River & 0.40 & 0.30 & $S$ & Little Red Bluff Creek \\
\hline Ashburn, city of & Turner & Little River & 1.16 & 0.03 & $\mathrm{~S}$ & Hat Creek \\
\hline Sycamore, city of & Turner & Little River & 0.01 & 0.01 & $\mathrm{~S}$ & Little River Tributary \\
\hline Jeffersonville, city of & Twiggs & Lower Oconee River & 0.25 & 0.14 & $\mathrm{~S}$ & Turkey Creek \\
\hline Loganville, city of & Walton & Upper Ocmulgee River & 0.57 & 0.29 & $\mathrm{~S}$ & Big Flat Creek \\
\hline Monroe, city of & Walton & Upper Ocmulgee River & 1.86 & 1.48 & $S$ & Jacks Creek \\
\hline \multicolumn{7}{|l|}{ Social Circle, city of } \\
\hline Little River WPCP & Walton & Upper Ocmulgee River & 0.69 & 0.34 & $\mathrm{~S}$ & Little River \\
\hline Spearman Pond & Walton & Upper Ocmulgee River & 0.05 & 0.03 & $S$ & Spearman Pond \\
\hline Waycross, city of & Ware & Satilla River & 6.70 & 2.81 & $\mathrm{~S}$ & Satilla River \\
\hline \multicolumn{7}{|l|}{ Warrenton, city of } \\
\hline Garland Street Pond & Warren & Upper Ogeechee River & 0.02 & 0.01 & $\mathrm{~S}$ & Golden Creek Tributary \\
\hline Northside Pond & Warren & Upper Ogeechee River & 0.05 & 0.03 & $S$ & Golden Creek Tributary \\
\hline Southside Pond & Warren & Upper Ogeechee River & 0.30 & 0.29 & $S$ & Golden Creek Tributary \\
\hline Sandersville, city of & Washington & Lower Oconee River & 1.70 & 0.91 & $\mathrm{~s}$ & Tanyard Branch \\
\hline Tennille, city of & Washington & Ohoopee River & 0.29 & 0.20 & $S$ & Dyers Creek \\
\hline Jesup, city of & Wayne & Altamaha River & 2.50 & 1.53 & $\mathrm{~S}$ & Altamaha River \\
\hline Alamo, city of & Wheeler & Little Ocmulgee River & 0.07 & 0.05 & $\mathrm{~S}$ & Alligator Creek \\
\hline Glenwood, city of & Wheeler & Lower Oconee River & 0.11 & 0.16 & $\mathrm{~S}$ & Peterson Creek \\
\hline Abbeville, city of & Wilcox & Lower Ocmulgee River & 0.15 & 0.06 & $S$ & Ocmulgee River \\
\hline \multicolumn{7}{|l|}{ Rochelle, city of } \\
\hline Rochelle Northwest WPCP & Wilcox & Alapaha River & 1.10 & 0.50 & $\mathrm{~S}$ & Mill Creek \\
\hline Rochelle Southeast WPCP & Wilcox & Alapaha River & 0.04 & 0.05 & $S$ & Mill Creek \\
\hline Gordon, town of & Wilkinson & Lower Oconee River & 0.40 & 0.27 & $\mathrm{~S}$ & Little Commissioners Creek \\
\hline
\end{tabular}

(1) Discharge from this facility did not occur during 1990.

(2) Discharge data is for 1991 .

${ }^{(3)}$ This plant is located in the Upper Ocmulgee River basin, hovever, effluent can be discharged to either the Chattahoochee River basin or the Ocmulgee River basin.

${ }^{(4)}$ The amount of water discharged during 1990 into the Upper Ocmulgee River basin was unknown.

${ }^{(5)}$ Includes the Newton County STP totals. 
76 National Water Quality Assessment of the Georgia-Florida Coastal Plain Study Unit-Water Withdrawals and Treated Wastewater Discharges, 1990 